\title{
ESTUdos geológicos E geofísicos DA SERRA de aRACOIabn E aRREDORES, ESTado de sio paulo
}

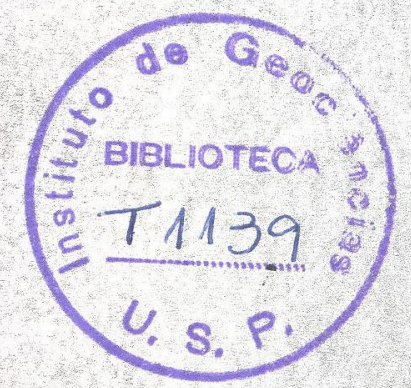

Tese de Doutoramento apresentada por ANDRE DAVINO

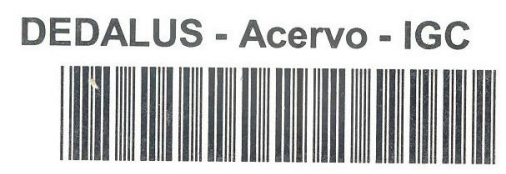

30900013444 


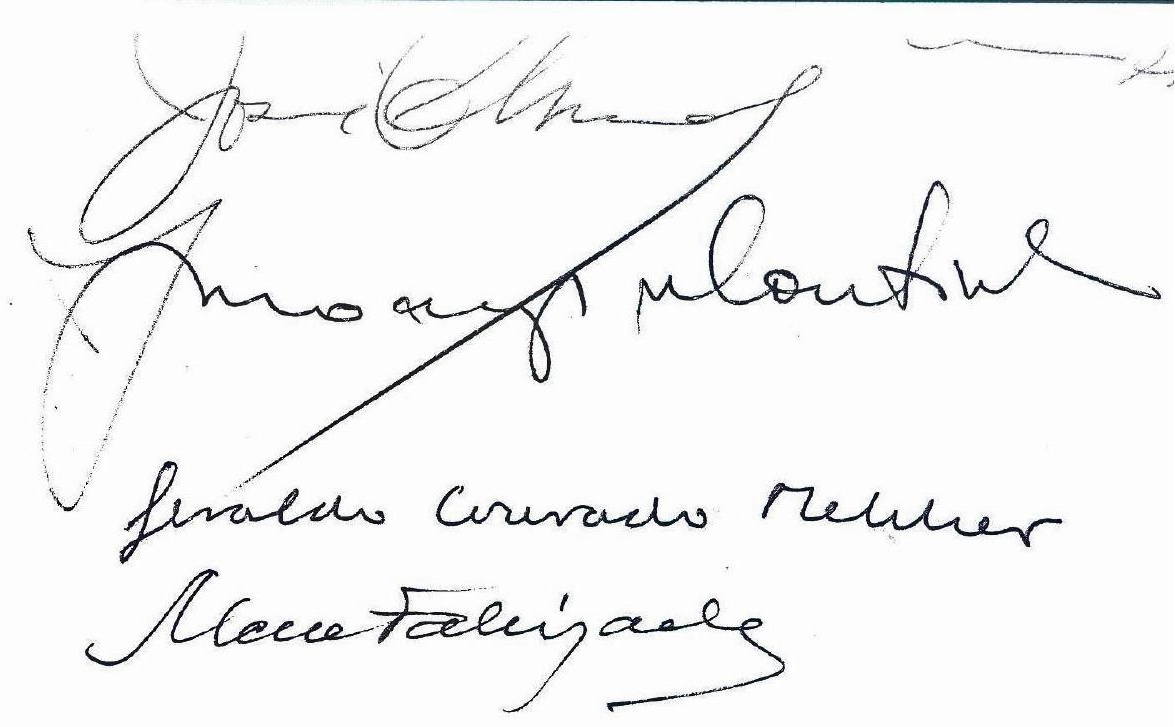

ESTUDOS GEOLOGICOS E GEOFISICOS

DA SERRA DE ARACOIABA I ARRDORES,

ESTADO DE STO PAULO

Tese de Doutoramento apresentada por AIDRE DAVINO

CAPH-9PB

-1965 - 
RESUIO

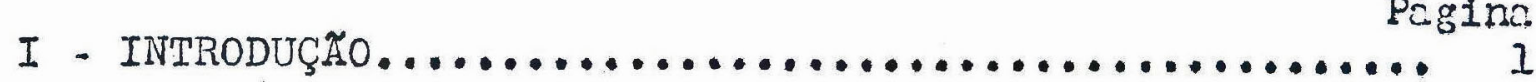

II - GEOLOGIA REGTONAL...................... 4

III - ESTUDO GEOLOGICO DA REGITO DA SERRA DE ARACOIABL... 6

1- Trebelinos anteriores

2- 0 mapa geológico e os métodos utilizados no seu levantamento

3- Litologia

4- Estruturas

5- Considerações gerais

IV - ESTUDOS GEOFISICOS...................... 26

1- Pesquisa gravinétrica

2- Invest1gação pelo nétodo de eletrorresistiv1dade

3- Estudos magnetométricos

$\mathrm{V}$ - CONCLUSOES FINAIS........................ 46

VI - BIBLIOGRAFIA.......................... 49

1 mapa geológico

2?. 1Iustrações

15 fotografias 


\section{RISUT:O}

Asto trebertho coresente os rosultacos dos investigaçoos goolónices o coofísicas eíctuadas na scrre de Lreçoiabe o arredoros, Istcclo do jẽ̃o Faulo. Na parto central desta sorre (érea da Fezende de Inenoma) afloran rochas alca lines, contondo concontraģos anôncles de atagnotita o apatita. As pesquisas tiveraa por finalidaco tontar elucidar o ne cenismo do intrusão dosses roches e estudcer a c distribuição dos donósitos do majnotita o epctita.

Foi claborado o acon goológico de rogião, en es

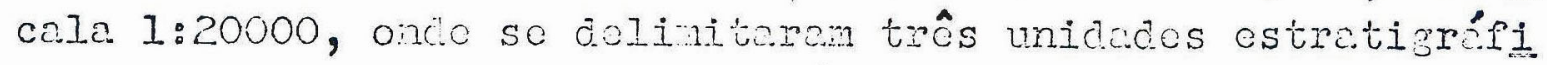
ces: ombasamonto cristelino (pró-cenbriano sup.?), Grupo Tubersão (permo-carbonf́foro) o intrusão alcoline (cretéceo infe

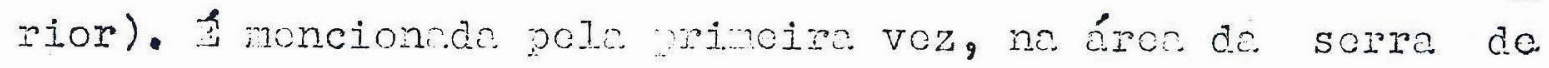
Arrȩoirba, a vroscnçe co rochas anfibolíticas o de "fenitos".

Os trebelhos geofísicos consistiran en levantamentos srovinótrico, co clctromesistividade o magnotomótrico. Os dedos formocidos polos cois primoiros métodos con-

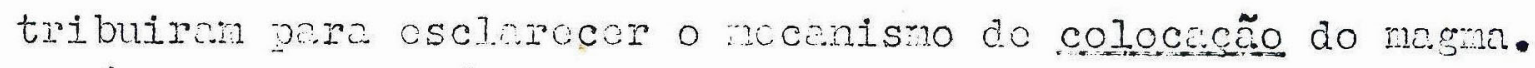
o sótodo argnotonótrico loi cmpogedo, rincipalmento, dera ostudar as possibilidedes do noves ocorrôncias do aregnetita.

***********

Os dedos obticos no presente trabollio permitiran concluir que a intrusco clcoline do Inenome poi do tipo

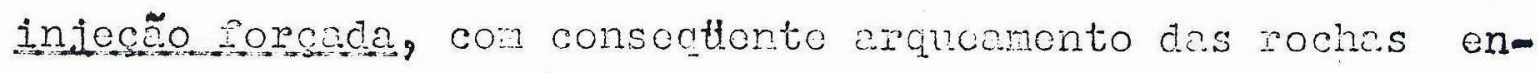
ceimentes; a coloceño do wegne foi controlede, principalinon to, pelas estrutures regioneis do complexo cristalino. Ldmi--

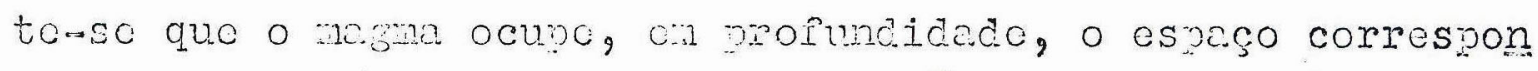
donto a. une foixe alongeda, do direção NE-SW, con algunas de 
zonas de quilônctros.

is jazidas de megnetite encontran-se, on grando parte, na forne de depósitos eluviais e concontraçõos in sttu a poucas dezenas de netros de profundidado. Os levantanentos nesnotomótricos roveluran, no entanto a possibilidado de ocorrêncic dôsse nineral entre 100 e 200 metros de profundidade,

Os levantanchtos negnctonétricos podcrão auxilier na localizaş̃o dos dopósitos de apatita, descie que se. jarn conheciacs as relaçõos cntre êstes depósitos e os de mornetita. 


\section{I - INIRODUCAO}

\section{- presente trabalho teve início em junho}

1962, quando, pela primeira vez, um levantamento magnetométrico era levado a efeito na área da serra de Araçoiaba.

Essa peculiar feição morfológica, situada ao norte da cidade de Araçoiaba da Serra (fig. 1), eleva-se a 300 metros acima do relêvo circunvizinho, expresso por superfícies de ondulação suave, nas quais as diferenças de nfvel não ultrapassan u ma centena de metros. A altitude média da região é de $570 \mathrm{~m}$, porém, o ponto culminante da serra alcança 967 metros. A serra estende-se em direção NW-ST por 8 $\mathrm{km}$, e sua largura chega a atingir $6 \mathrm{~km}$. A drenagem se aprasenta em disposição radial ao redor da serra, sendo os principais coletores de água: o rio Ipanema, o ribeirão do Ferro e o rio Iperó, todos afluentes do rio Sorocaba.

A importância da serra de Araçoiaba, do i ponto de vista geológico, deriva do fato de conter una das muitas ocorrências de rochas alcalinas do Brasil. As concentrações de magnetita e apatita nessas rochas despertaram, desde Ionga data, especial interêsse sôbre a área. O contôrno da intrusão alcalina situa-se na parte central da serra e está contido inteiramente dentro dos limites da Fazenda Fiederal de Ipanema.

são:

As finalidades principais do presente trabalho

a - tentar esclarecer o mecanismo da intrusão do corpo alcalino de Ipanema e sua posição, no espaço e no tempo, dentro da estrutura regional da área

b - investigar as possibilidades de novas ocorrências de minério de ferro e de apatita. 


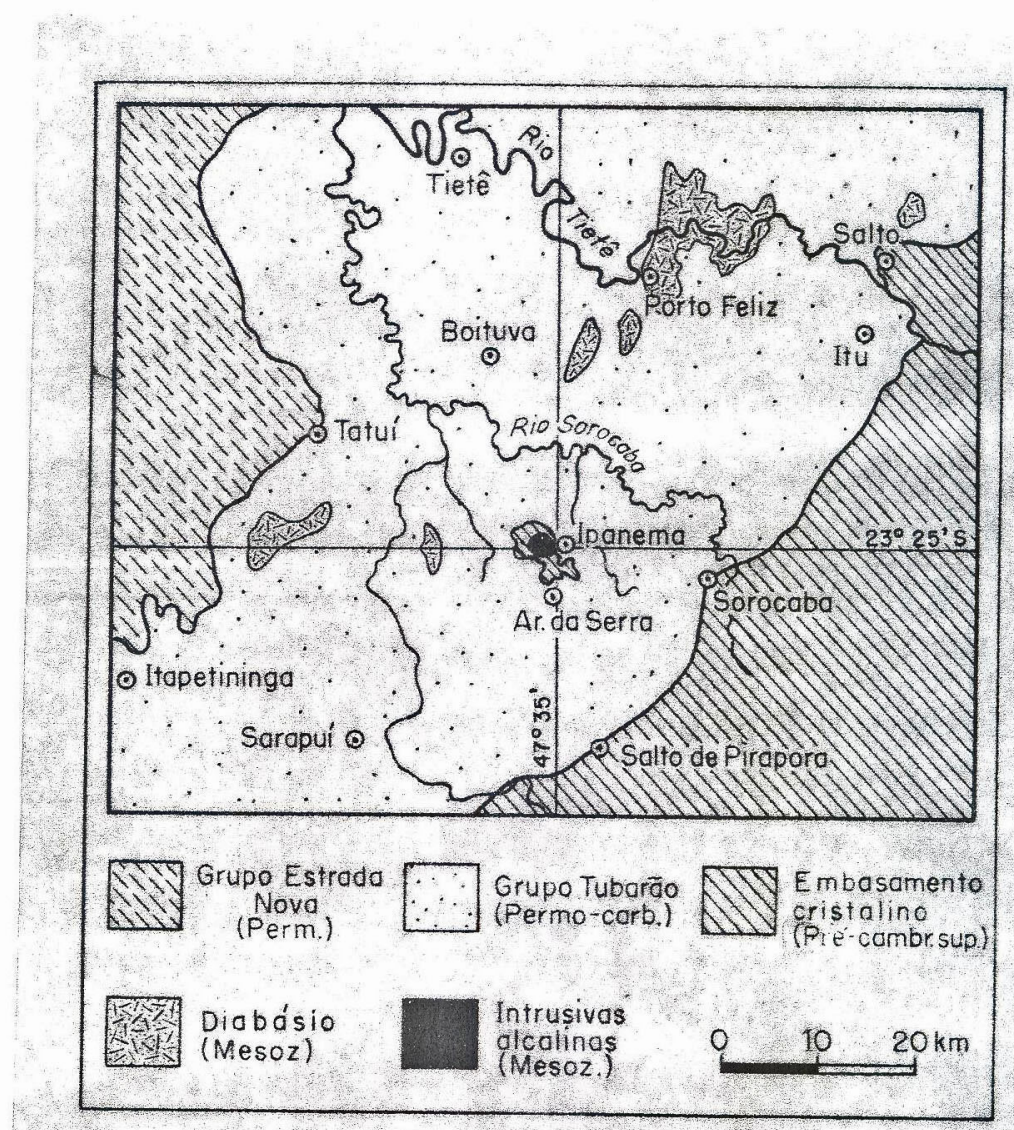

Fig. 1- Mapa geológico regional. Localização de Ipanema e dos lugares citados no trabalho (adapt. Mapa GeoIógico, I.G.G. - 1963). 
Para alcançar tais objetivos foram feitas investigações geológicas e geofísicas. As primeiras consistiram no levantamento geológico da região da serra de Araçoj aba e as segundas, nos levantamentos gravimétrico, magneionétrico e de eletrorresistividade.

Na presente investigação foram dispendidos 110 dias de trabalho de campo; funcionando equipes de três pessoas, em média, por dia. Perfazendo, portanto, um total de 330 dias-pessoas.

\section{Agradecimentos}

Consignamos aqui os nossos agradecimentos a todos que auxiliaram na realização dêste trabalho. Ao Prof. Rudolf Kollert, que, desde 1959 até meados de 1964, nos conduziu no verdadeiro caninho das pesquisas geofísicas, acompanhando-nos no campo e orientando-nos nas interpretações dos resultados dos levantamentos, devemos a execução desta obra. Ao Prof. Dr. Viktor Leinz, nossa gratidão pelo amparo e crítica emprestados durante o desenvolver das pesquisas. Ao Prof. Dr. Josué Camargo Mendes e Prof. Dr. Sérgio Estanislau do Amaral devemos vários conselhos sôbre a apresentação do trabalho.

O texto foi revisto e discutido pelo Prof. Clemente Segundo Pinho, da Cadoire de Língua Portuguêsa da Faculdade de Filosofia, Ciências e Iêtras de Araraquara, Ao Prof. Pinho, sinceros agradecimentos.

De alta importância foran o auxílio financeiro prestado pela Fundação de Amparo à Pesquisa do istado de são paulo, bem como, a acolhida e facilidades que tivemos na Fazenda Federal de Ipanema, por parte do administrador, Engo Agro Dr. Agesislao S. Pereira da Silva. Em Ipanema, recebe nos do $\mathrm{sr}$. Gino Giubbini várias informações e anostras das sondagens executades ao redor da pedreira de calcário da Com prinia de Cimento, Ipanema, que inuito nós auxiliaram.

Nas Cadeirus de rísica Geral e Ixperimental, Ele trônica e Física do Estado Sólido da Faculdade de Filosofia, 
Clências e Lêtras da U.S.P., obtivemos preclosas informa乌ões e nos fol permitido realizar grande número de experiên cias de laboratório. Somos gratos a todos que nos auxilia ram, de modo especial ao Prof. Iuda D. G. Lejbsman, à Profa Suzana Villaça e ao Prof. Katuchı Techina. O Prof. Dr. Carlos quadros propiciou facilidades na determinação da suscep tibilldade magnética das rochas.

0 Enge Ludovico Taliberti, chefe do Serviço de Geodésia do Instituo Geográfico e Geológico de são Paulo pôs à nossa disposição os dados altimétricos do Estado de São Paulo e nos informou sôbre as experiências e resultados obtldos com o altimetro Wallace \& Tlernan.

Ao nosso colega, geólogo Yociteru Hasui, devemos o auxílio no exame de algumas lâminas de rochas; ao geó logo Umberto Cordani, a a juda na preparação do trabalho de triangulação radial; ao Dr. Reinholt Ellert, agradecemos o empréstimo de um mapa e as fotos aéreas, da área, bem como a descrição petrográfica dos testemunhos de um poço existen te na Fazenda Ipanema. Ao geólogo Celso B. Gomes, do Departamento de Mineralogia e Petrologia da U.S.P., devemos o es tudo e a descrição pormenorizada do anfibolito existente na área de Ipanema. Aos alunos do Curso de Geologia de São Pau 10 que participaram das nossas pesquisas, devemos especiais agradecimentos. Ales completaram as equipes geofísicas, auxiliaram nos milhares de cálculos feitos e abreviaram o tem po de execução do trabalho de campo.

A todos, a nossa gratidão. 


\section{II - GEOLOGIA REGIONAL}

A serra de Araçoirba situa-se geológicamente na faixa do Grupo Iubarão (v. fíg. I) do "Sistema" de Santa Catarina, que, nessa região do Istado de São Paulo, repousa diretamente sôbre o embasamento cristalino.

o Grupo Lubarão, de idade permo-carbonífera(Men des, 1961 ), é constituído de rochas de origem glacial e periglacial. Contém, em algumas áreas, intercalações marinhas depositadas nos períodos interglaciais. Possui mergutho regional muito suave para oeste, acompanhando a superfície topográfica do embasamento cristalino.

A ordem de grandeza do mergulho regional da superfície do embasamento cristalino pôde ser calculado a partir de dados de sondagens (v. tabola 1 , poço de São Pedro) e de eletrorresistividade (por exomplo, en Jupira, município de Pôrto Feliz, êste mótodo indicou o embasamento crista lino a -50 metros de altitude). As determinações permitiram calcular um mergulho ao redor de 1 a a $1030^{\prime}$ para Nw.

Admitindomse constante êste merculho, o embasamento cristalino deveria encontrar-se a uns 300 metros de altitude na região da serra de Araçoiaba. No entanto, 0 embasamento aflora nessa serra em altitudes superiores a 850 metros.

Tm extensão regional ocorrem intrusivas bósicas (diabásios) associadas ao vulcanismo mesozóico do sul do Brasil (Leinz, 1949), cortando ou intercalando-se nas camadas do Grupo Tubarão.

Os dados de sondagens que interessam ao presente trabalho estão transcritos no tabela 1. Como pode ser notado, o Grupo Tubarão atinge espessuras consideróveis, que ultrapassam 1000 metros, enquanto sills (ou lacólitos?) de diabásio apresentam até mais do 200 metros de espessuras (Mez zalira, 1958, p. 51). Eintorossante observar a pequena es- 
pessura do Grupo Tubarũo na sondegem I $(160 \mathrm{~m})$, localizada a pouco mais de $2 \mathrm{~km}$ do érea da intrusc̃o alcalina de Ipanema.

Tabela 1- Dados de sondagens (*)

\begin{tabular}{|c|c|c|c|}
\hline \multirow[b]{2}{*}{ Local } & \multicolumn{2}{|c|}{$\begin{array}{l}\text { Espessura. } \\
\text { em metros }\end{array}$} & \multirow[b]{2}{*}{ Observa.ções } \\
\hline & $\begin{array}{l}\text { Grupo } \\
\text { Iubarão }\end{array}$ & Diabásio & \\
\hline Anga tuba & 1136 & 117 & $\begin{array}{l}\text { atingiu o embasamento cristali } \\
\text { no }\end{array}$ \\
\hline $\begin{array}{l}\text { S. Pedro } \\
\text { Ipanema }\end{array}$ & 1131 & 215 & iden \\
\hline (I) & 160 & - & $\begin{array}{l}\text { atingiu o embasanento cristali } \\
\text { no a } 420 \mathrm{~m} \text { de altitude. Poço } \\
\text { na sede da Fazenda Ipanema }\end{array}$ \\
\hline (II) & 106 & - & $\begin{array}{l}\text { atingiu o embasamento cristali } \\
\text { no atravessou tros corpos } \\
\text { (silis?)denochas a } 1 \text { calinas, com } \\
\text { espossuras de } 10,2 \text { o } 5 \mathrm{~m} \text {. Al- } \\
\text { titude do cmbrimonto: } 514 \mathrm{~m}\end{array}$ \\
\hline (III) & 63 & - & $\begin{array}{l}\text { nẽo atingiu o embasamento cris } \\
\text { talino, atravessou } 2 \text { corpos de } \\
\text { rochas alcalinas de } 0.2 \text { e } 0.5 \\
\text { m de espessura }\end{array}$ \\
\hline
\end{tabular}

(*) Os dados referentes a Ipanema foram fornecidos pela Cia. de Cimento Ipanema; os de $\mathrm{S}$. Pedro e Angatube foram reproduzidos da puolicação de lezzolira (1958, p. 51 ). 


\section{III - ESTUDO GEOLOGICO \\ DA REGITO DA SERRA DE \&RCOIABA}

Ao iniciarmos os trabalhos na área de Ipanema, estudada geológicamente por vórios autores, tínhamos pràticemonto tôdes a.s iniormaçõos sôbre sua litologia e algumas idéias do sou tectonlsmo. A gênese das rochas alcalinas, bom cono o modo de formação das jazidas de megnetita o apatita já tinhan sido investigados preliminarmente. Um rape geoló gico levantedo por Inccht e publicado por loraes (1938) cons tituiu valioso auxílio na erecução dos nossos levantamentos, tanto geológicos cono geofísicos.

\section{1 - Trabaihos anterioros}

2 região de Ipanema ostão Iigados os prineiros fctos rolacionados à história da geologia no Brasil. 4 serra do iraçoiabo ( $f i g .2)$, constituindo uma anomalia zorfolágica na suave topografic ondo so ergue, dove tor muito côdo chomado a atenção dos homens que conquistaram o interior do Brasil. Consta quo, desolo o sćculo XVI, oram conhecidas a.s jazides de icrro de Ipanone. No início do século XIX. instalou-se ali a Fábrica do Ferro de Sẽo João do Ipanema.

Com a trensferência da Coroa Portuguêsa para o Brasil, a convite de Portugal chegou ao Brasil, om 1809, Luiz Hilhelm Vamhagen, incumbido de desenvolvor a siderurGla instalada em Ipanoma. Em 1818 corria forro-gusa na Fábrica de Ipanena, onde fôra instalado un dos primeiros altos-fornos quo funcionou no País, tondo trabalhodo ativanon te durente a Guerra do Paraguai.

Roscnbusch (1870) foi o primciro a reconhecer a martita, quo.ocorro on Ipaneina, como produto pscudonóríico de inegnetita. 


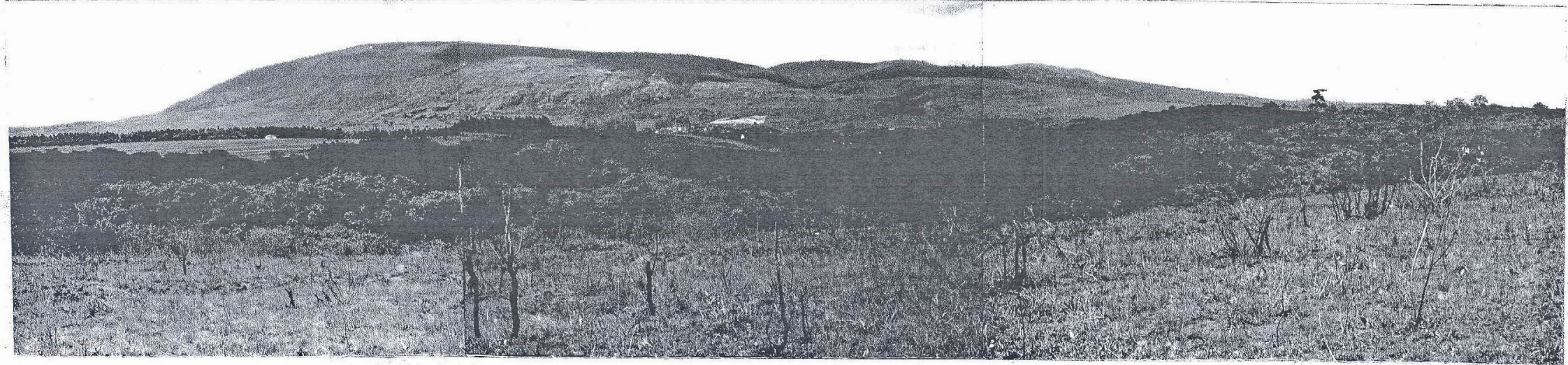

Fig. 2- A serra de Araçoiaba vista da estrada Ipanema-Pôrto Feliz 
A primeira menção sôbre a existência de apreciável quantidade de ácido fosfórico no solo que envolve os blocos de magnetita das jazidas de Ipanema se deve a Dupré (1884). Só em I89I, porém; Derby mostrou que a apatita ocorre como ura dos constituintes das rochas alcalinas. Neste trabaIho, Derby (1891) fêz obscrvaçoses sôbre a geologia da região e reconheceu alguns diques licados à intrusão alcalina.

Vinte anos nais tarde, Gonzaga de Campos, en relatório inédito (seg. Kinecht, 1930, pp. 6 e 2l) fêz estudos aprofundados sôbre os recursos de magnetita de Ipanena.

Uma nova fase das investigações começa a partir de 1927, quando o govêrno do Istado de São Paulo e, posterior mente, o dovêrno da União interessaram-se pela exploração da apatita para fabricação de adubo. A esta fase estão ligados inicialnente os nomes de Guilherme Florence e Theodoro Knecht, mais tarde, os de Luciano Jacques de lioraes, Moraes Rêgo, Viktor Leinz e outros.

Guilherme Florence, encarregado das pesquisas pelo Govêrno paulista, conseguiu localizar vários corpos de minério fosfático.

Knecht (1930) apresentou a primeira secção geológica da serra de Araçoiaba, alén dos estudos comparativos das jazidas de ferro e da apatita, tendo avaliado as suas reservas.

Moraes (1938) sintetiza tôdas as pesquisas geológicas feitas até essa data e apresenta sugestões para a ins talação de una fábrica de superîosfatos, aproveitando o minério de Ipanema. Iloraes Rêgo. (1938) e Araújo (1939) estudaram o aproveitamento da apatita.

Leinz (1940) publica estudos petrogenéticos sôm bre as rochas alcalinas, com especial referência às ocorrências de apatita.

Embora Instalada a usina de beneficianento e até nesmo iniclada a produção de superfosfatos, tôdas as tentativas de exploração da apatita resultaram antieconôinicas.

Dos trabalhos mais recentes, fora da área da intrusão alcalina, nas que a ela fazen nenção, cita-se o de 
Niaciel e Guimarães (1955). Estes Autores descrevem e discutem a origem de un dique de composição semelhante ao shonkinito-pórfiro que ocorre en Ipanema, situado no bairro do Congonhal, município de Tatuí. Knecht (1960) descreve una ocorrência de rocha alcalina tanbém macroscòpicamente semeIhante ao shonrinitompórfiro de Ipanema, no bairro dos Soares, município de piedade.

\section{2 - O mapa geológico}

e os métodos utilizados no seu levantamento

No mapa geológico que apresentamos estão individualizadas as seguintes unidades estratigráficas:

embasamento cristalino (pré-cambriano sup.?) Grupo Tubarão (permo-carbonífero) intrusão alcalina (mesozóico).

Assinalamos por neio de lêtras as rochas principais e, por meio de símbolos convencionais, os elementos estruturals medidos. Dentro da área do embasamento cristalino delimitanos a ocorrência de anfibolito, por ser esta unidade litológica pela primeira vez mencionada como tal. Secções geológicas são nostradas na fig. 3.

$\mathrm{Na}$ execução do levantamento geológico, contamos con o auxílio valioso de fotografias aéreas em escala aproximada 1:20000. Como mapa-base, servimo-nos da carta topográfica da Fazenda Ipanema, publicada en 1928 pelo Servico Geográfico do Exército, na escala $1: 20000$ e com curvas ac nível de 10 em 10 metros.

As fotografias aéreas foram utilizadas com os seguintes fins:

a) como base planimétrica dos levantamentos geológicos _e e 


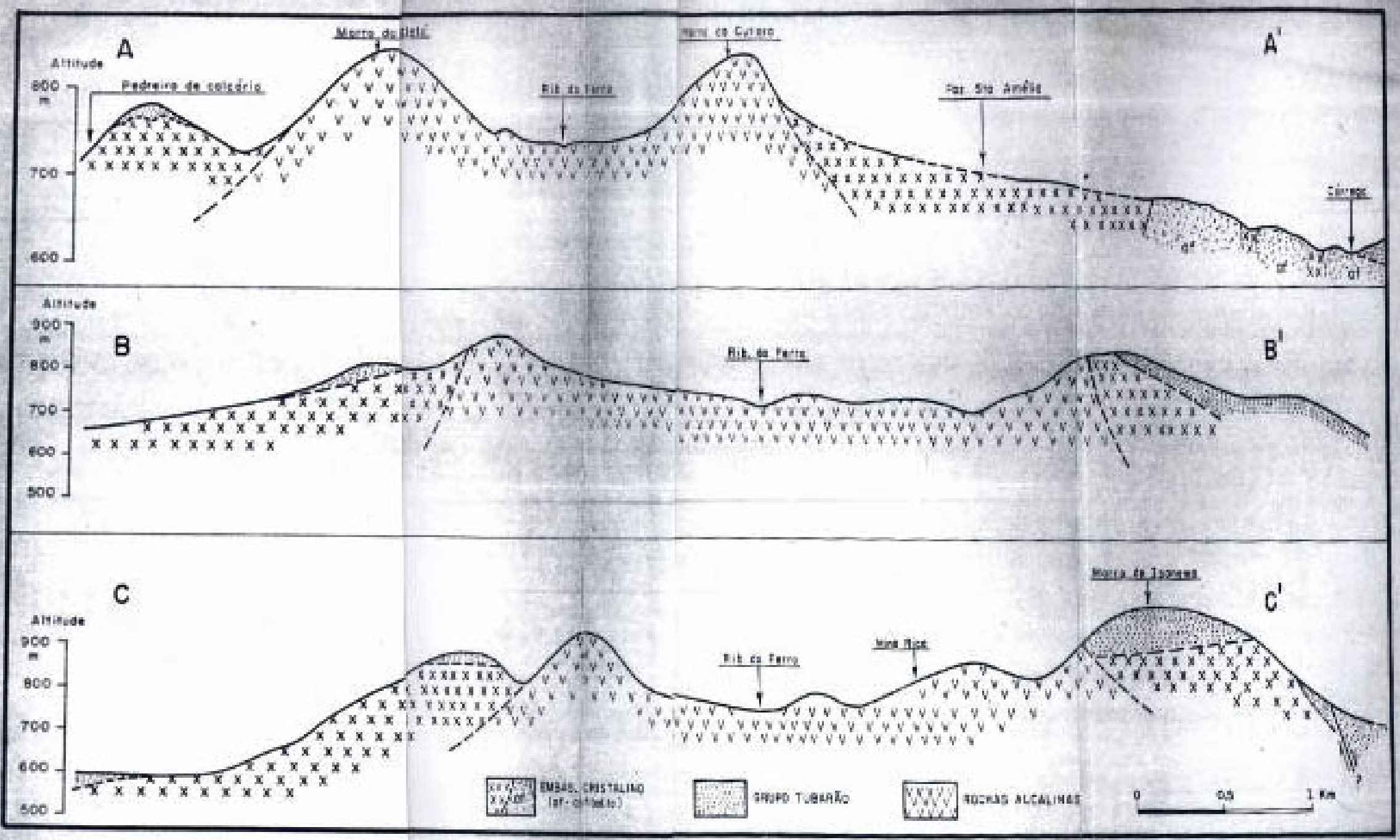

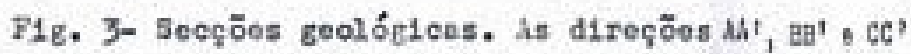
estrio indiesdes no mapa geológitos. 
mente. Tanto as observações geológicas cono as estações de medidas geofísicas foran rogistradas nas fotografias aéreas. As observações geológicas consistiram no reconhecimento e descrição macroscópica das rochas e em nedidas de elementos estruturais.

\section{b) na ampliação da área do mapa-base}

Como a carta topográfica da Fazenda Ipaneña näo abrange tôda a ćrea mapeada, tivenos de ampliá-la planimótrí camente para o sul e para leste, com auxílio das fotografias aéreas. Foi utilizado o processo de triangulação radial (Smith, 1943, pp. 159-173), com pontos de contrôle tirados da própria carta topográfica.

c) na interpretacão fotogeolóğica

Com o auxílio do estudo estereoscópico das foto grafias aéreas, puderam ser traçados quase todos os contornos das unidades mapeadas e alguns elenentos estruturais.

As características principais de cada unidado geológica mapeada, do ponto de vista da interpretação fotogeológica, estão resumidas no quadro abaixo:

\begin{tabular}{|c|c|c|c|c|}
\hline $\begin{array}{l}\text { Unidadades } \\
\text { geológicas }\end{array}$ & $\begin{array}{c}\text { Formas do } \\
\text { relêvo }\end{array}$ & $\begin{array}{l}\text { Padrão e tex- } \\
\text { tura da drena- } \\
\text { gem (*) }\end{array}$ & $\begin{array}{l}\text { Distribui- } \\
\text { ção da ve- } \\
\text { getação }\end{array}$ & Côr do solo \\
\hline $\begin{array}{l}\text { embasamen- } \\
\text { to crista- } \\
\text { lino }\end{array}$ & $\begin{array}{l}\text { arredonda.. } \\
\text { das }\end{array}$ & $\begin{array}{c}\text { dendríticos } \\
\text { fina. }\end{array}$ & densa & $\begin{array}{l}\text { clara (fili- } \\
\text { tos e grani- } \\
\text { tos) escura } \\
\text { (anfibolito) }\end{array}$ \\
\hline $\begin{array}{l}\text { Grupo } \\
\text { barão }\end{array}$ & tabulares & $\begin{array}{l}\text { retangular } \\
\text { grossa }\end{array}$ & rarefeita & clara \\
\hline $\begin{array}{l}\text { intrusivas } \\
\text { alcalinas }\end{array}$ & $\begin{array}{l}\text { arredonda.. } \\
\text { das }\end{array}$ & $1 *(*)(*)$ & densa & escura \\
\hline
\end{tabular}

(*) Smith (1947, pp. 127-131)

(*) (*) Neio puderam ser caracterizados por causa da pequena área de ocorrência dessas rochas. 
As características apresentadas pelas rochas do embasamento cristalino e as alcalinas são pouco distintivas. Conseguimos, no entanto, mapear com certa facilidade o contato entre essas duas unidades com o auxílio de levantamentos magnéticos ( v. p. W4).

Im relação às estruturas, puderam ser reconhecidas e traçadas por meio do estudo estereoscópico as direções das diáclases (abertas) do Grupo Tubarão e as direções de alguns provåveis falhamentos.

$$
\text { As figuras } 4 \text { (e } 4 \mathrm{~A} \text { ) e } 5 \text { (e } 5 \mathrm{~A} \text { ) ilustram o uso }
$$
das fotografias como auxiliares no mapeamento e no traçado de diáclases e falhas. As áreas dessas figuras estão localizadas na fig. 6 .

\section{$3-$ L1tologia}

\section{A - Embasamento cristaline}

As rochas do embasamento cristalino que afloram na região de Ipanema são metassedimentos do Grupo São Roque, anfibolito e granito, tôdas consideradas do pré-cambriano superior. Com exceção do setor leste e sudeste, estas rochas se situam (v. mapa) ao redor da área da intrusão alcalina, numa faixa que, a partir do norte, alarga-se para oeste e para 0 sul. Essa faixa atinge até $5 \mathrm{~km}$ de largura. Uma área de anfibolito, de forma irregular, ocorre isolada e cercada por sedimentos, a leste da intrusão alcalina; o mesmo parece dar-se coin o granito que se localiza a algumas centenas de metros ao norte da cidade de Araçoiaba da Serra.

Metassedimentos do Grupo São Roque predominam na zona norte e em grande parte da região sul e sudeste da intru são alcalina. São filitos ( $f i g \cdot 7$ ) de coloração prateada, quan do frescos, e amarelada a ligeiramente vermelha, quando decompostos. As faixas de filito passam gradualmente ìs de calco-xisto, até calcários metanórficos, de coloraçăo escura, 


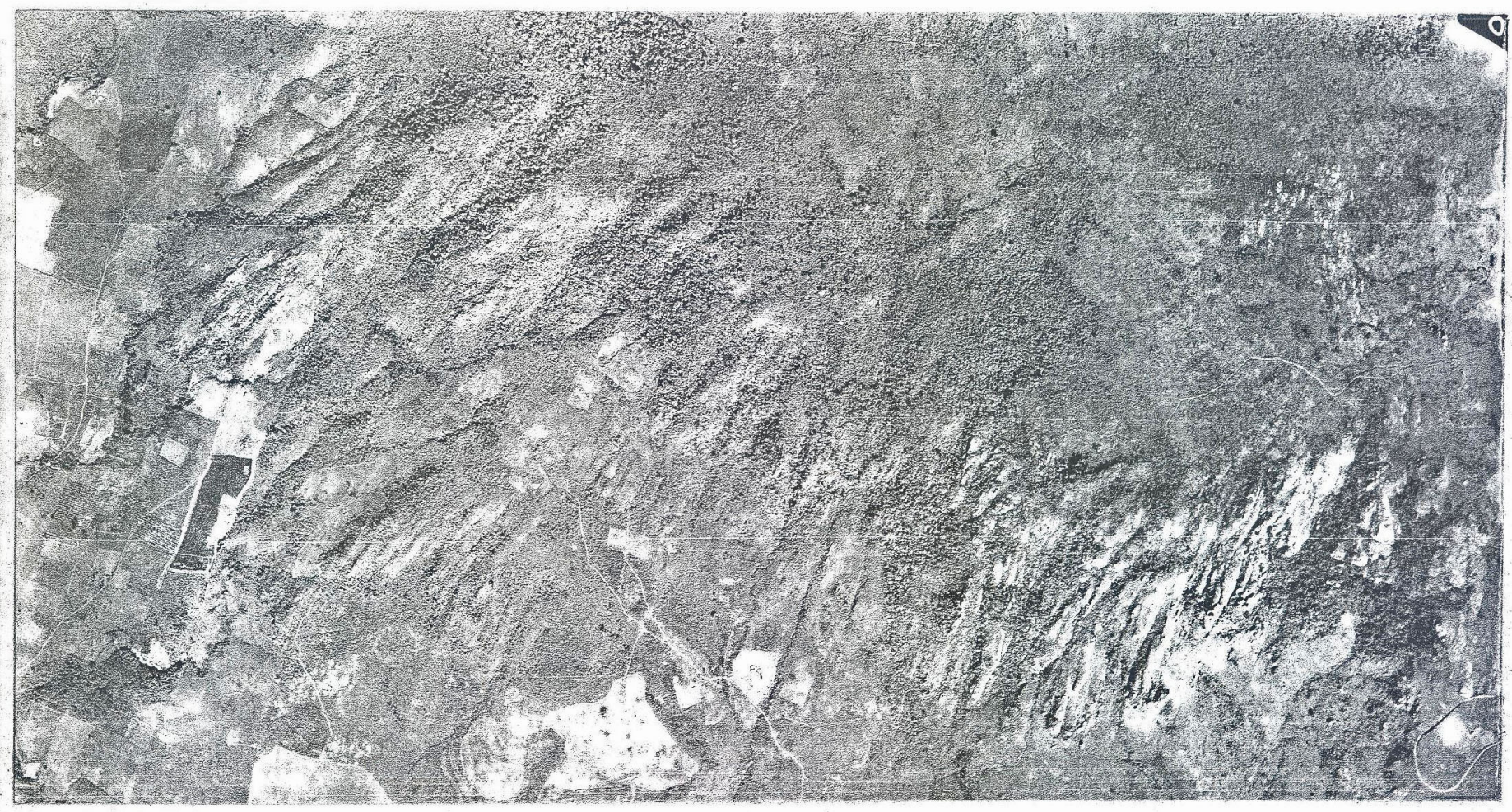

Fig. 4-Setor de uma fotografia aérea vertical da área leste-sudeste da serra de Araçoiaba. Notar a disposição das diáclases (foto do Serv. Aerof. Cruzeiro do $\mathrm{SuI} S / A$ ).

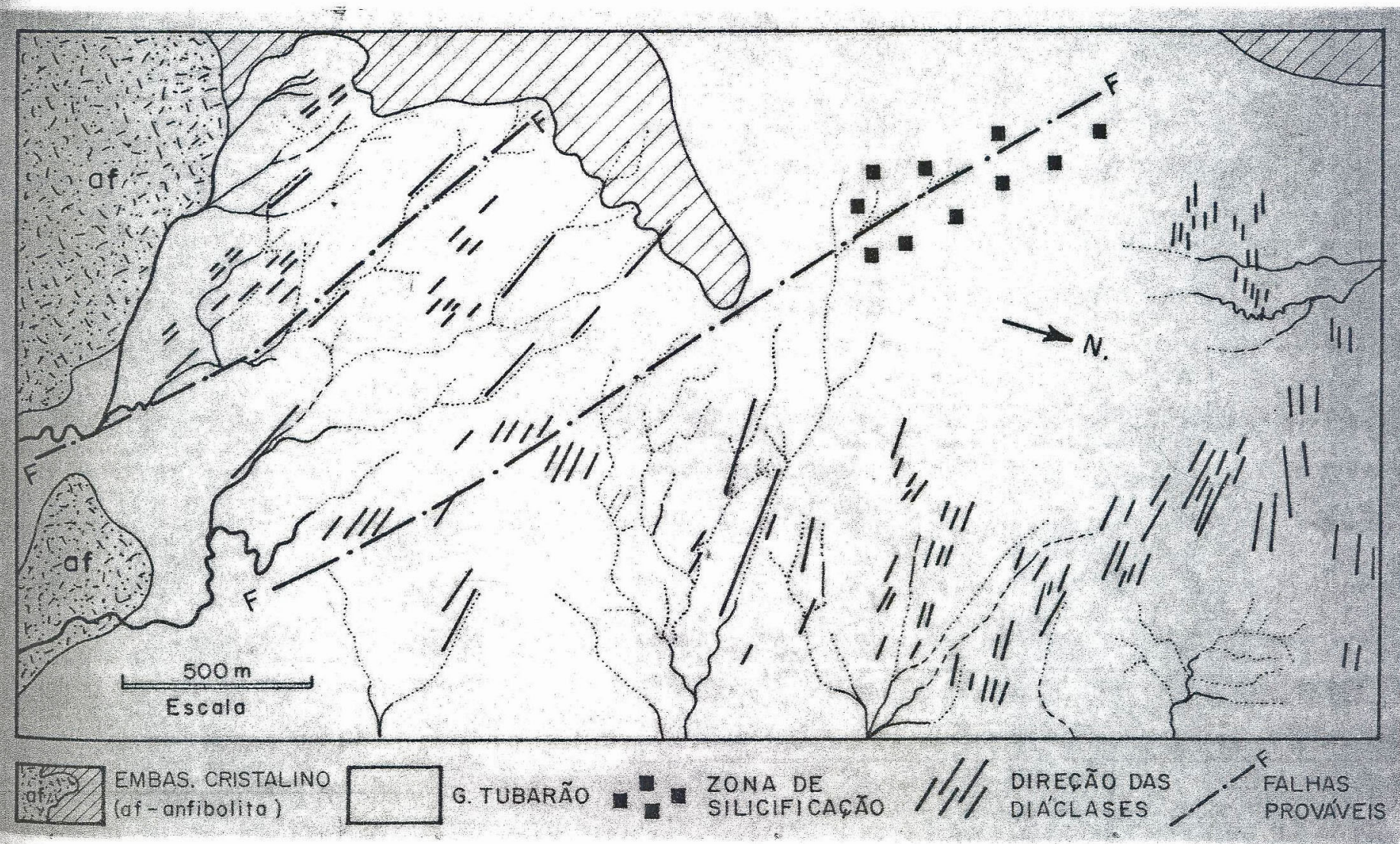

Fig. LA- Reprodução de alguns pormenores geológicos da figura 4. 


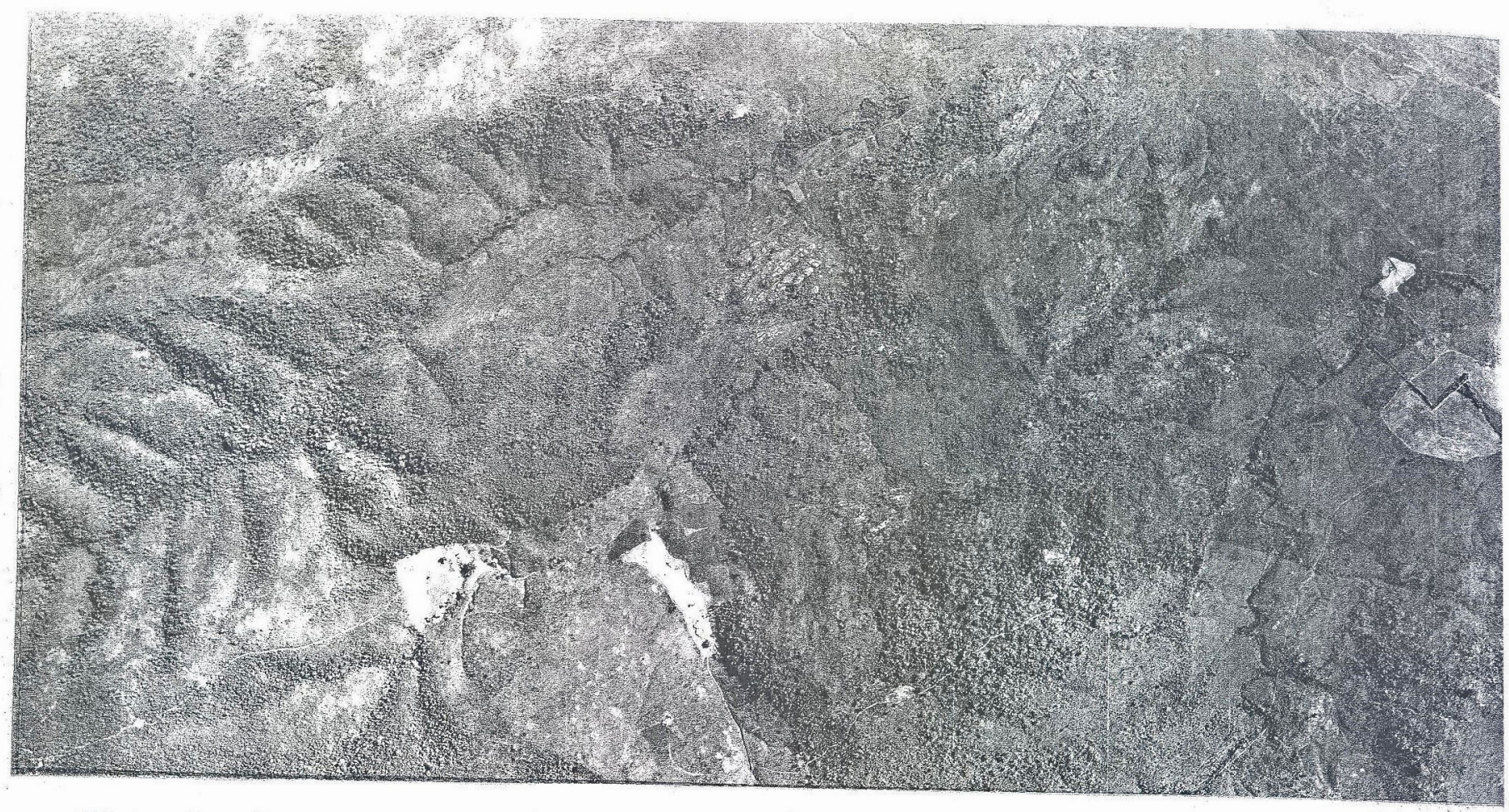

Hig. 5- Setor de uma fotografia aérea vertical da área norte da intrusão alcalina. observa-se nítida diferença entre os padrões de drenagem e formas de relêvo do embasamento cristalino e Grupo Tubarão (foto Serv. Aerof. Cruzeiro do Sul S/A).
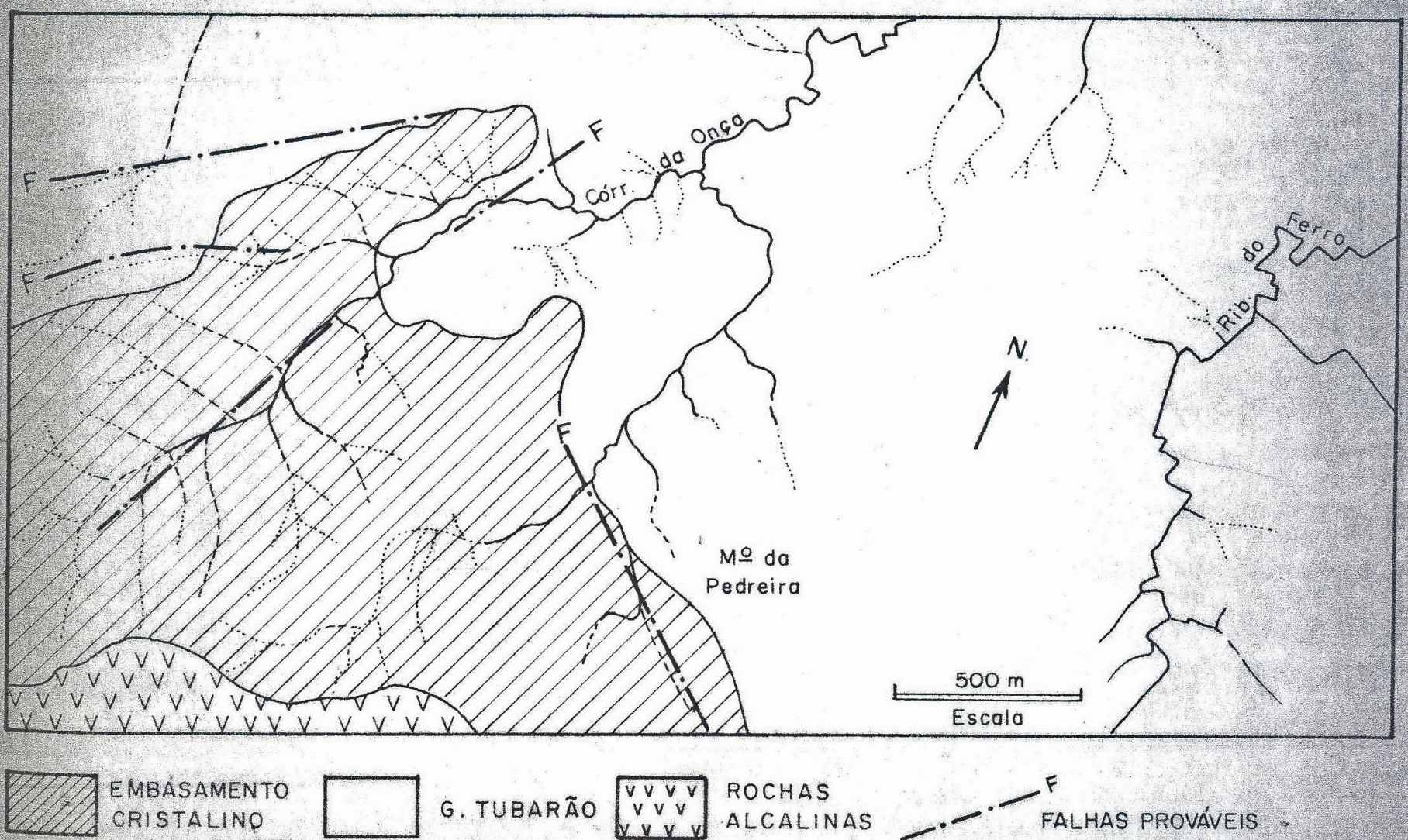

G. TUBARÃO
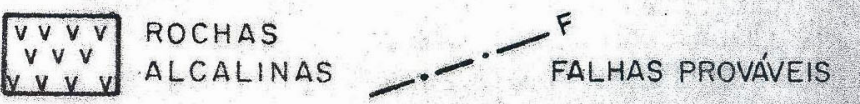

Hig. 5A- Reprodução de alguns pormenores geológicos da figura 5. 


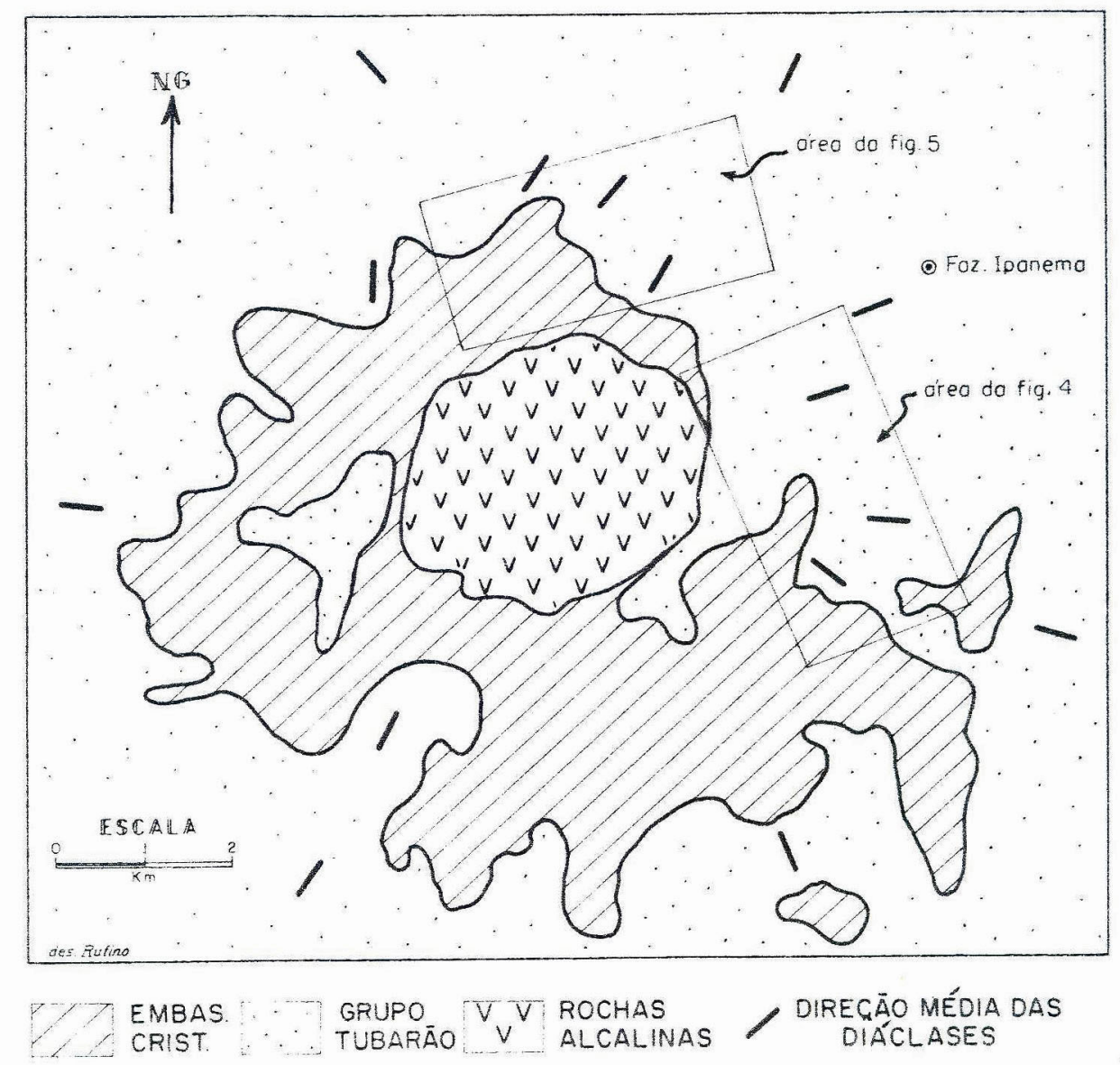

Fig. 6- Lccalização das éreas das figuras 4 e 5 . Noter a disposição radial das diáclases representadas. 
com notável quantidade de fissuras preenchidas por calcita (fig. 8). Êste calcário é explorado na fabricação de cimen to. Foram encontrados en alguns pontos da área mapeada tam bém micaxistos e quartzitos.

\section{Anfibolito}

Dsta rocha (fig. 9), descrita primciramente como diorito por Inecht (1930, p. 9) aparece posteriormente em seu mapa geológico (publicado por Moraes, 1938) como "dlabásio e rochas associadas". De fato, à primeira vista, - solo argiloso e de coloração vermelha intensa dos anfibe litos lembra muito o solo proveniente de diabásio.

o estudo petrográfico de uma dezena de lâminas delgadas indicou tratar-se realmente de anfibolito. Um su mário dêste estudo, ieito pelo geólogo Celso B. Gomes, do Departamento de Mineralogi a Petrologia, é dado a seguir. Quase tôdas as rochas anfibolíticas da região de Ipanema apresentam-se inteiramente recristalizadas. Sua granulação varia de fina a grossa. Nota-se nas de granulação fina incipiente alinhamento dos cristais de anfibólio. Nas rochas de granulação grossa é frequente a presença de porfiroblastos de anfibólio e feldspatos, com quartzo e minerais opacos cono principais inclusões.

Processos de deformação mecânica, in lica os pe lo encurvamento dos linhas de clivagem dos cristais de anfibólio e presença de plagioclásio granulado foram obser vados em quase tôdas as ainostras.

A textura é blastofítica. O plagioclásio, ripiforme,exibindo gerninação complexa, e a presença de núcleos de piroxênio, no interior dos cristais de anfibólio constituem as feições texturais mais notáveis dessas rochos,

Anfibólio e plagioclásio são os principais componentes mineralógicos dessas rochas, constituindo quase sempre mais de $90 \%$ de sua composição.

o anfibólio é uma hornblenda verde comum, com pleocroísmo de z passando de verde escuro a verde azulado. 


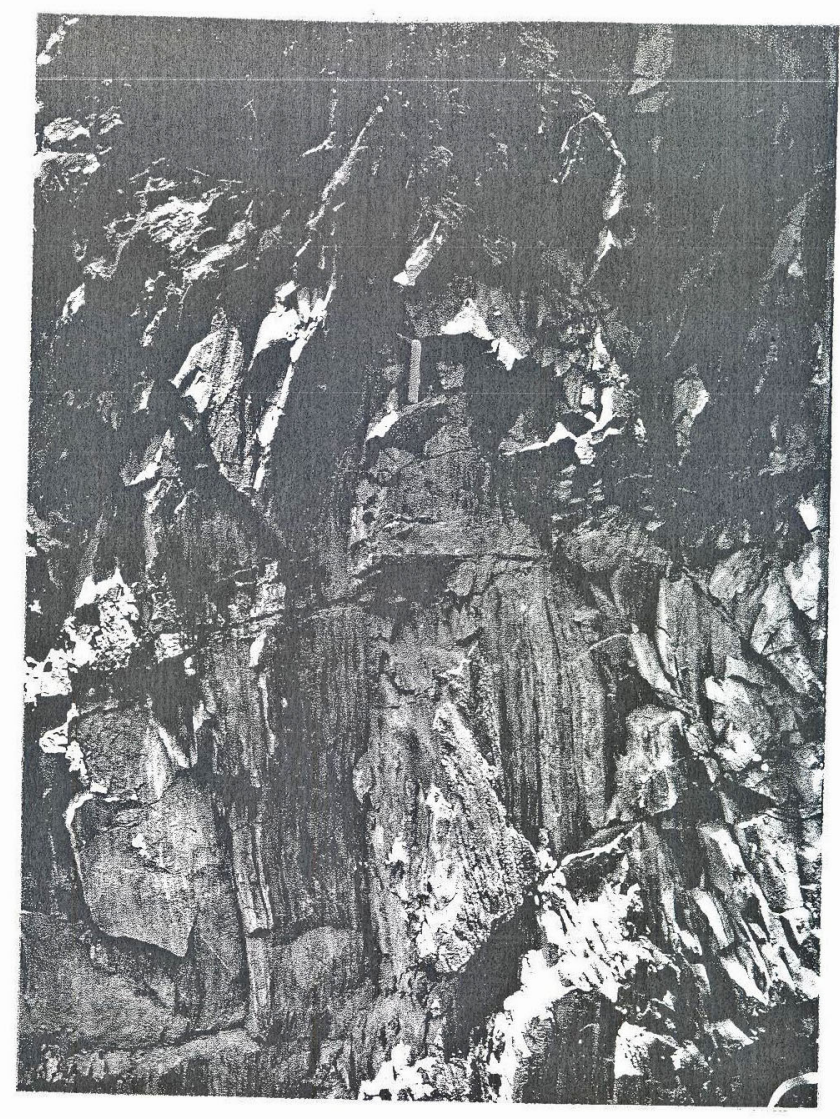

Fig. 7- Embasamento cristalino. Filjto fraturado e amarrotado. "Estrada pera as minas".

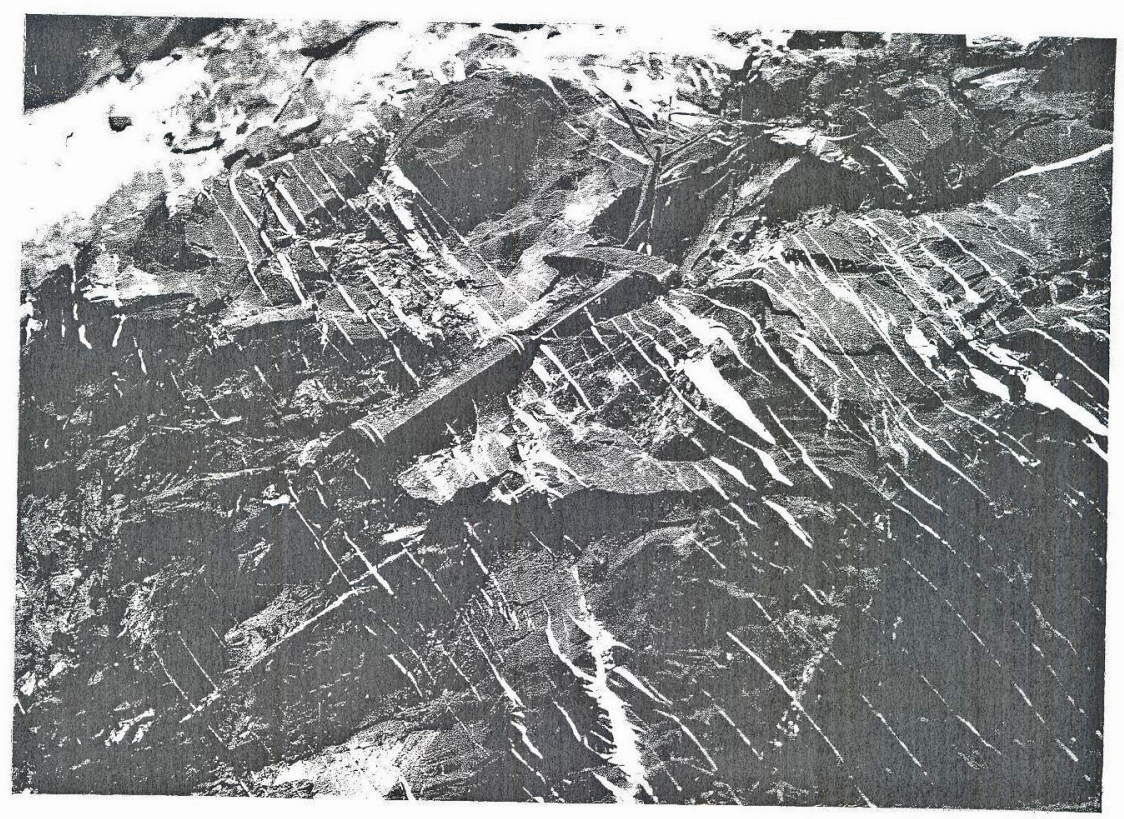

Fis. 8- Imbasamento cristalino. Calcério motanórfico. Notar as fissuras preenchidas por calcita. FE dreira de Cia de Cimento Tpanena. 


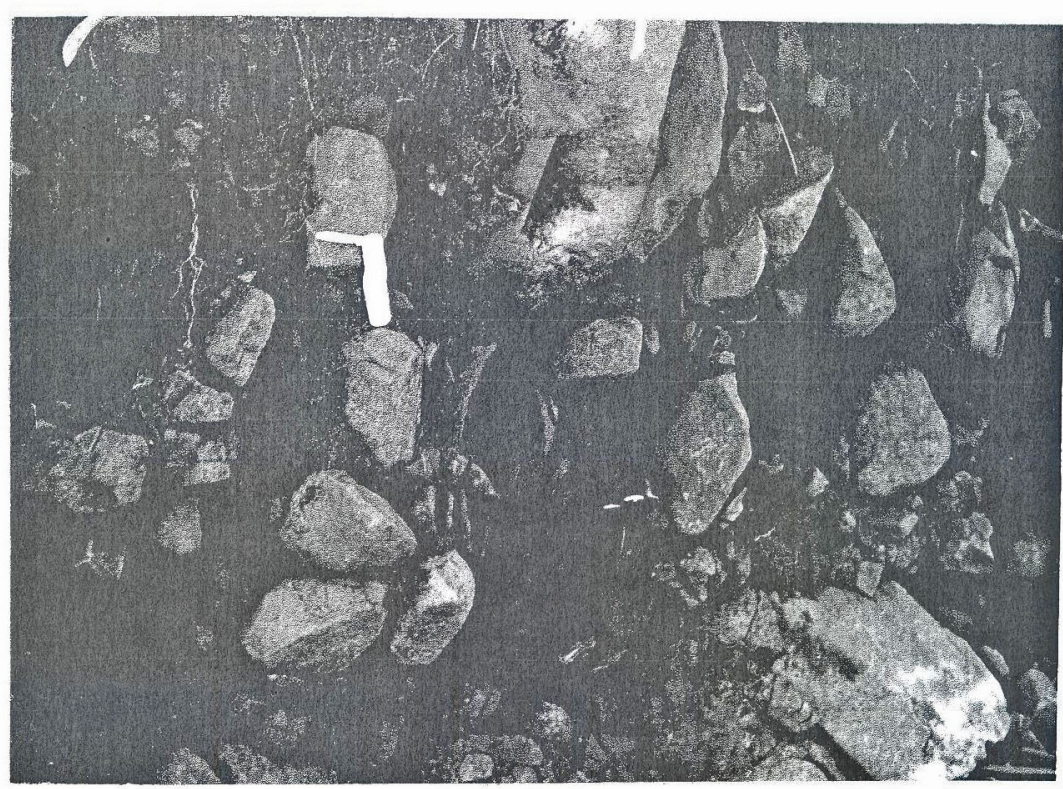

His. 9- Enbessmento cristalino. Aspecto do afloramento de enfubolito na Fazenda Senta Amélia.

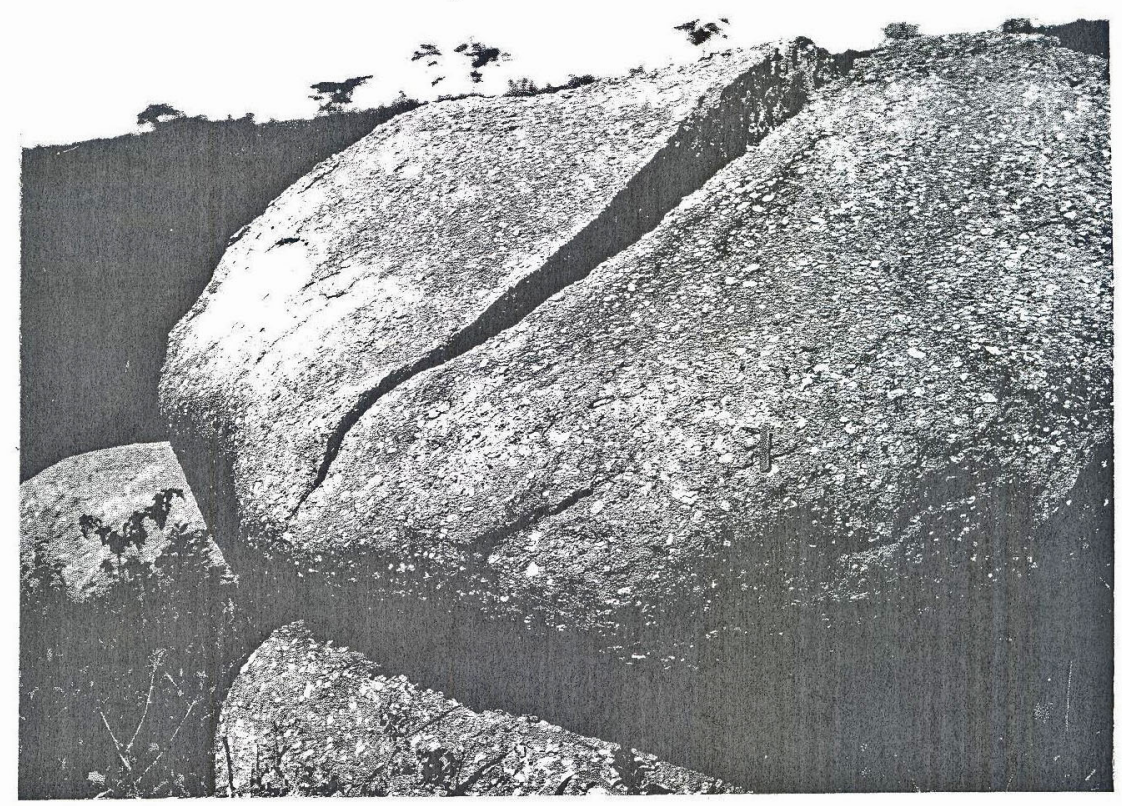

Fis. 10- Lmbesamento eristalino. Afloramento de granito a SE da serra de Aracoiaba, sftio do Snr. Mám rio Sanches. 
Nas amostras mais xistosas, apresenta estrutura zonada, oxibindo, nas partes centrais, côres conumente mais pálidas que nas bordas.

o plagioclásio, determinado pelo método de liichel-Lévy, tern sua composição situada dentro do campo de va rłação da andesina. Apresenta-se frequlentemente granulado e desprovido de clivagens e geninação, porém, om rochas menos afetadas pelo processo metamórfico, possui hábito ripiforme e mostra-se geninado segundo as leis da Albita e Carlsbad. Minerais do grupo do epídoto (clinozoisita e pistacita), titanita e opacos constituem os acessórios mais importantes. Os primeiros, ocorrendo na forma de agregados, associam-se intimanente ao plagioclásio e parecem ter-se formado às suas exponsas. A titanita é encontrada na forma de agregados, comunente dispersos ao redor dos minerais opa $\cos$.

Biotita, quartzo e turmalina, presentes em pequenas quantidades, foram igualmente identificados.

Os granitos predominam em tôda a faixa a oeste da intrusão alcalina. Ocorrências não indicadas no mạa geo lógico de Knecht aparecem a sudeste, próxino do bairro de Araçoiaba.

Encontram-se dois tipos macroscòpicamente dife rentes de granitos. Na faixa a oeste da intrusão lcalina, esta rocha possui coloração rósea e textura eqưigranular, com cristais de ató $1 \mathrm{~cm}$, enquanto o granito que aflora a sul e a sudoste (rig. 10) é claro e apresenta foldspatos (mitcroclínio?) às vêzes de mais de $3 \mathrm{crn}$.

\section{B - Gruno Tubarão}

Guase tôdas as rochas do Grupo Tubarão (tilitos, conglomerados, arenitos conglomeráticos, arenitos, 
siltitos, folholhos e sedincitos vérvicos) são encontrados na área da serra de Araçoiaba, com visível predominância de arenitos geralmento arcozianos. Canadas e lentes de conglonerado, de alguns centímetros a mais de I netro de espessura, são encontrados nos pacotes de arenitos. São estas intercalações, bem cono as de sedimentos siltosos e argilo sos, que permiten porcober ligelra estratificação nos arloramentos de aronito expostos nos 300 netros de desnível do flanco leste da serra de ḱraçoiaba (fig. 1I). Não pudemos precisar quantos níveis de tilito ocorrem na área estudada, mas, parcec haver pelo menos un nível rejousando sôbre o embasamento cristalino (v. Leinz, 1937, p. 29). De fato, o maior afloramento de tilito que encontranos se situa na Fazenda Itaiaquira, diretanente sôbre rochas do embasamento (anfibolito). Outros arloranentos foren encontrados en níveis diferentes (v. napa geológico).

As rochas do Grupo Tubarão, numa distância de 3 a $5 \mathrm{~lm}$ ao redor de érea des a.rcalinas, se aprosentem geralmente mais endurecidas do que en outras localidados. Amaral (1961, p. 97), que estudou os arenitos arcozianos da reGião de Ipanema, atribuiu ôsse endurecimento à siliricação suporficial notivada por causas de natureza clinćt1ca sem relação a magma e.lcalino. Leinz (1940, p. 25), por outro la do, vorificou en alguns pontos que as rochas sedinentares so freram a ação de netanorî́isino temal, provocado pela ação do megra alcalino. Este ação, porém, se restringiu a alguns netros ou a poucas dezonas de metros (iden, p. 26).

As rochas secinentares circundam tôla a borda exterior da ́́rea do embesamento cristalino ( $v$. rapa), com exceção do setor leste e sudeste de serra de Araçoiaba, onde estão dirotawento en conexão (contato inferido) con as intru sives alcalinas. Pode-se notar que, nos maiores elevaçōes da sorra do Areçoiaba, os sedimentos ainda se acham presentes. o que se observa eo redor do ponto culminante dessa árei, a 967 zetros de altitude. En alsumas zonas, man che isoladas de sodinentos do Grupo Tubarão, do poucos me- 


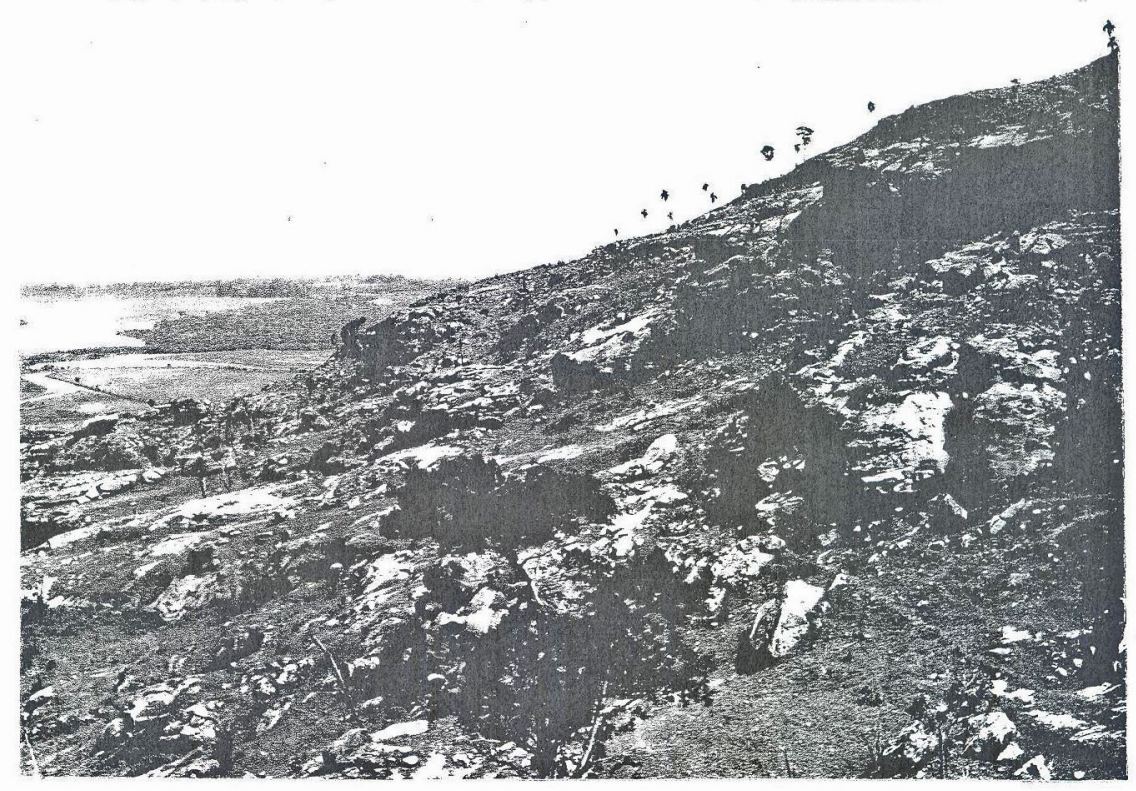

Fig. 11- Grupo rubarẽo. Notar o acamamento e as diáclases. Flanco leste da serra de Araçolaba.

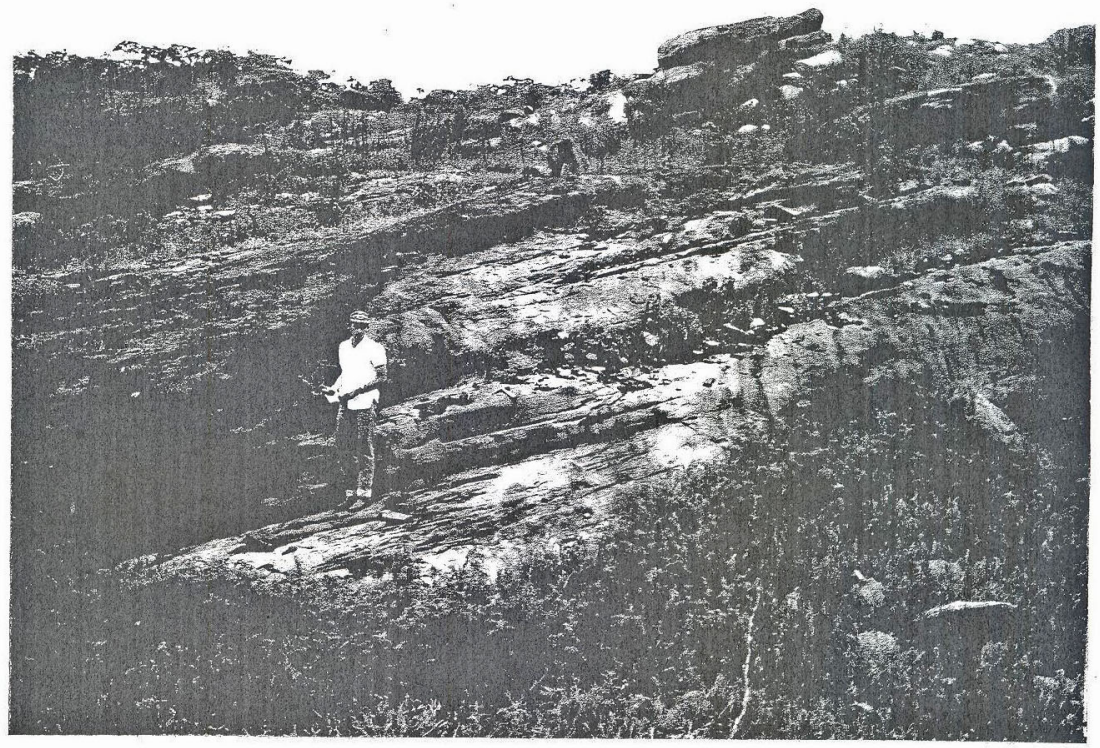

Fig.12- Grupo Tubarão. Camadas do Grupo Tubarão inclinadas de cêrca de 15․ Proximidades da pedreira de calcário da Cia. de Cimento Ipanema. 


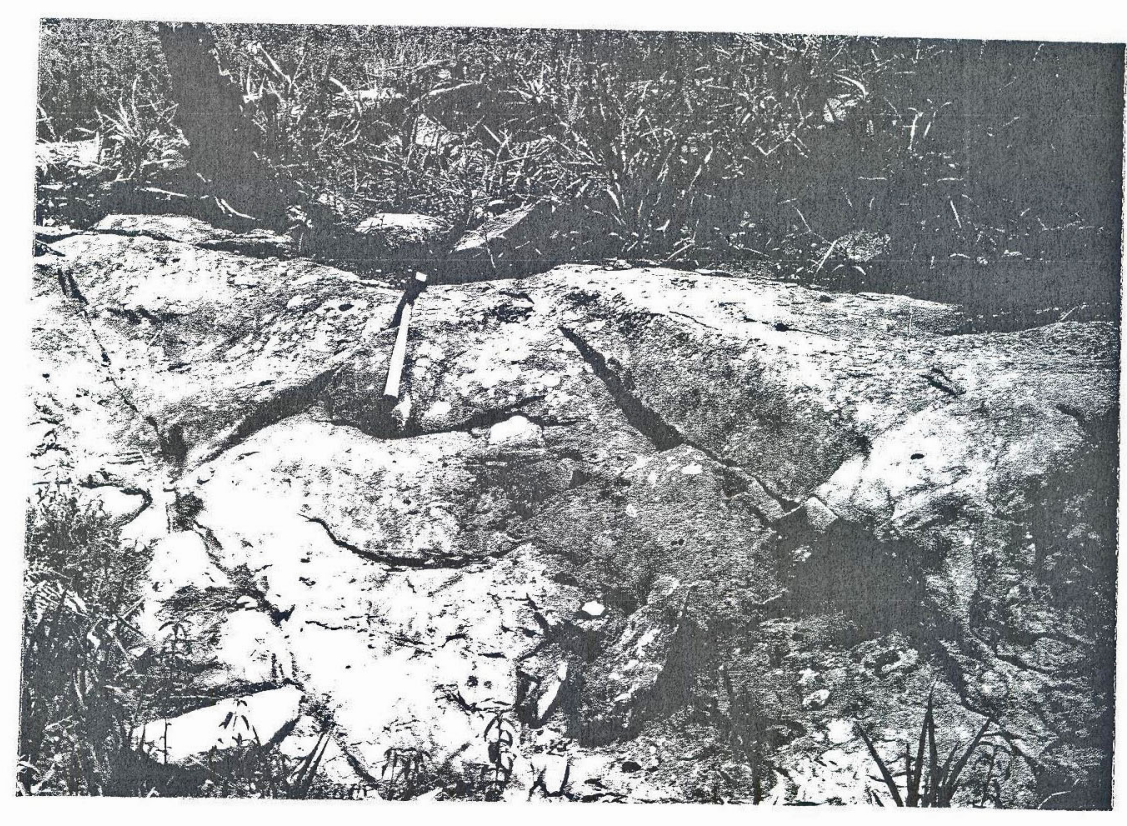

Fig. 13- Grupo Tubarão. Sistema de diáclases no arenito. Afloramento próximo ao córrego da cnça.

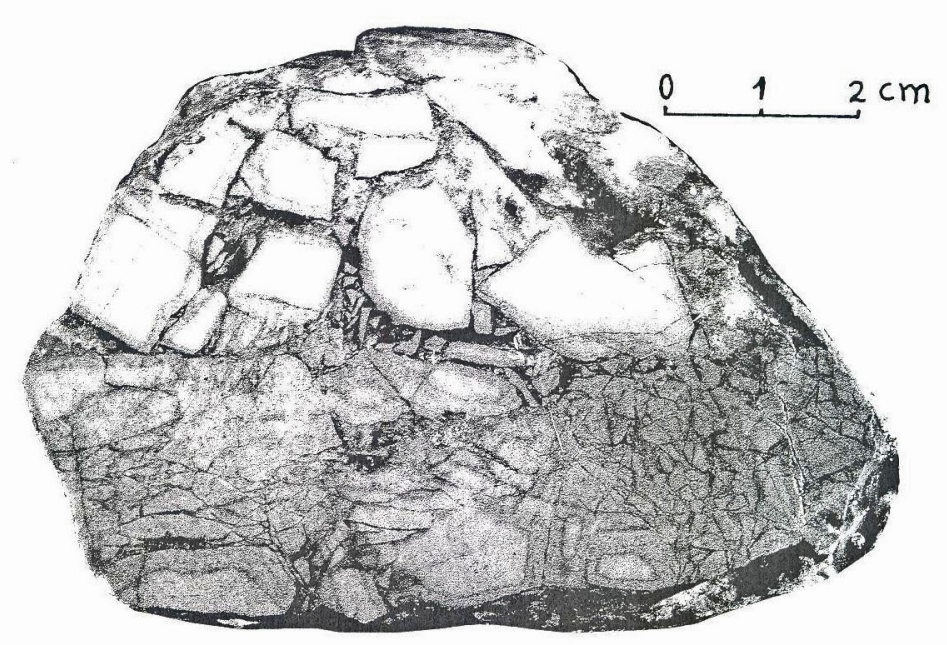

Hig. IL- Grvoo Tuberão. Gecçẽo polida de brecha de faThe no arenito. "Pingo Drgue". (foto J. C. Nendes). 
tros de espessura, ainda capelam o embasamento cristalino (v. mapa). Este foto possibilitou a obtenção de cotas da superfície original do embasamento cristalino ainda não destruída pela erosão atual.

\section{C - Intrusivas alcalinas}

A intrusc̃o nagnática de Ipanema ocupa direa aproximadamente circular de $9 \mathrm{~km}^{2}$. Sua superfície é drenado. pelo ribeirão do Ferro, que forma urn vale profundamente taIhado e priticamente linear, de direção NE-ST.

Duas medidas efetundas no Laboratório de Geocro nologia do Departamento de Geologia o Paleontologia da U.S.P. , segundo o método do potíssio-argônio, indicaran para as rochas alcalinas de Ipanema idade cretácea inferior.Es tas determinações form feites com biotita,contidas em shonkinitos-pórfiros.

A descrição petrogrófica mais completa e o único estudo genético das rochas alcalinas de Ipanema foram apresentados por Leinz (1940). Aste Autor distingue quatro ti pos principais de rochos plutônicas no ćrca, e as identifica cono ortoclásio-egirinito, ortoclásio-lusitanito, umpterito e nordmarkito. As rochas que constituem os sills e diques as sociados ̀̀ intrusão alceline foran classificados como shonki. nitos-pórfiros (rig. 15 e 16) pelo Autor citado. Como produtos anormais, aparecem concentrações de magnetita e apotita. Do ponto de vista genético, Leinz (1940, pp. 33-36)ernclui pon una diferenciaçĩo in loco do magma numa pequena cônara magkítica, pelo menos, até a formação dos egi rinitos. Numa faso posterior, o moma ter-se-ia injetado nas rochas encairantes.

Nâo se encontra ne ́́rea das rochas alcalinas prà bicomente nenhum afioramento, por estarem as mesmas profunda nente decompostas. F comm, toảuvia, acharem-se na área da intrusĩo, blocos do sílex de vários tamanos, alguns dos quajs com mais de un metro de diâmetro. Leinz (1940, pp. 27 a 


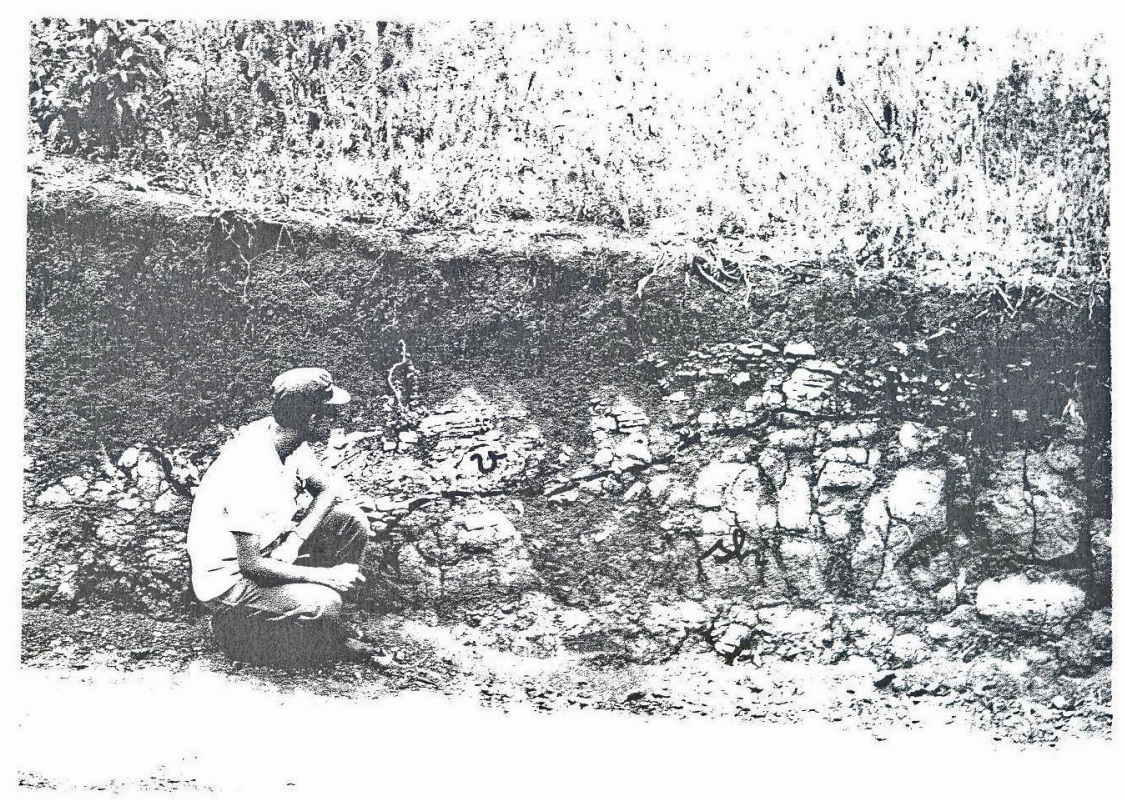

Fis. $15-\frac{\text { Rochas alcalinas. Sill de shonkinito-pópfiro }}{(\mathrm{sh}) \text { capeado por varvito (v). "Corte Grande". }}$

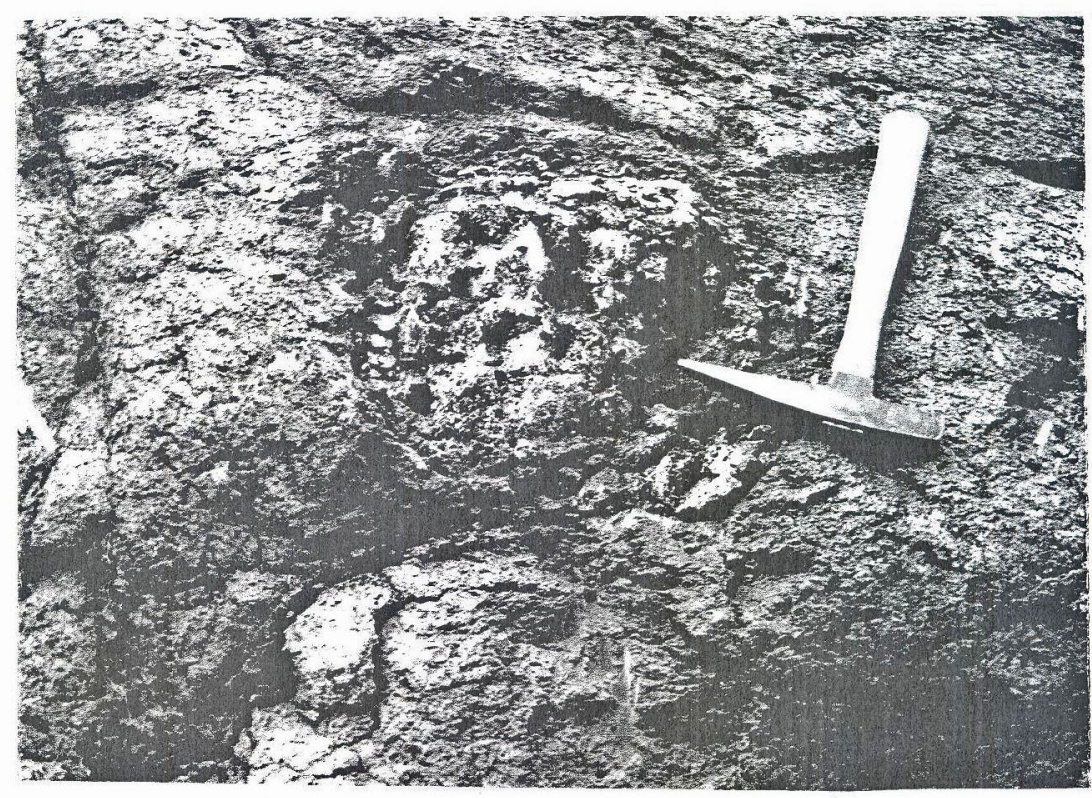

Iig. I6- Rochas alcalinas, Shonkinito-pónfiro, conterdo bloco de arenito. "Corte Grande". 
a 29) discute a formação dessas rochas silicificadas, admitindo como fonte mais provóvel! da sílica, soluções magmáticas residunis provenientes do últino produto de diferenciação magmática.

\section{"Fenitos"}

Durante os levantamentos dos perfis magnéticos efetuados na área das intrusivas alcalinas, chamou-nos a atenç̃̃o o fato de se encontrarem em vários pontos, além da grande quantidade de material silicificado, pequenos blocos rolados de rochas incipiontemente decompostas, ein muitas das quais se podia notar coloração esverdeada e estrutura oriontada. Estas rochas foram sistematicamente coletadas e o estu do microscópico revelou tratar-so de rochas fenitizadas. São rochas do embasamento cristalino, om sua maioria granitos e xistos, contendo geralmente egirina, que é o miner l conum a quase tôdas as rochas alcalinas de Ipanema. As figuras $17 \mathrm{e}$ 18 são fotogrnfias das seç̃óes polidas de exemplares de rochas fenitizadas. Estas rochas, de coloração esverdeada, apresentam faixas escuras de piroxênio que se suceden a faixas com minerais claros (quartzo e feldspatos), sendo a estrutura oriontada remanescente da xistosido da rocha. Não fi zezos estudo pormenorizado dos "fenitos", mas, queromos deixar registrada sua preschça na h́rea de Iponema.

\section{***水***}

Em resumo, dentro da śrea das"intrusivas alcalinas" (v. mapa geológico), além das rochas alcalinas, descritss por Leinz (1940), encontram-se outras unidades litoló gicas: sílex o restos dos rochas encaixantes, em parte afeta das netassomàticamente, por aç̃̃o do magma alcalino. Essas unidades ñ̃o form mapeadas, ñ̃o só porque a escala do tapa não comportaria, mas, principalmente, por serem exíguos os afloramentos. No mape geológico representanos tão-somente as principais ocorrôncias de sílex. 


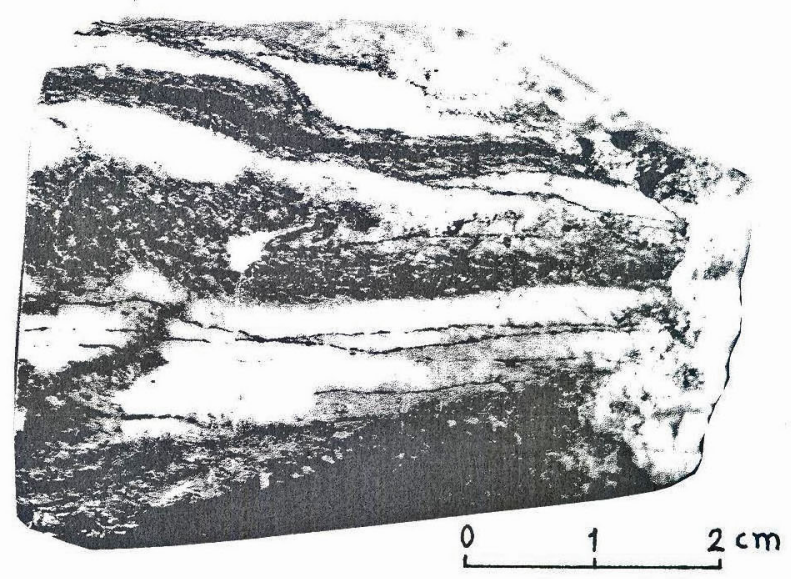

Fi.f. 17- "Fenito". As bandas escures correspondem a piroxenios e as clares, a quartzo e felespatos. (roto J. C. Mendes).

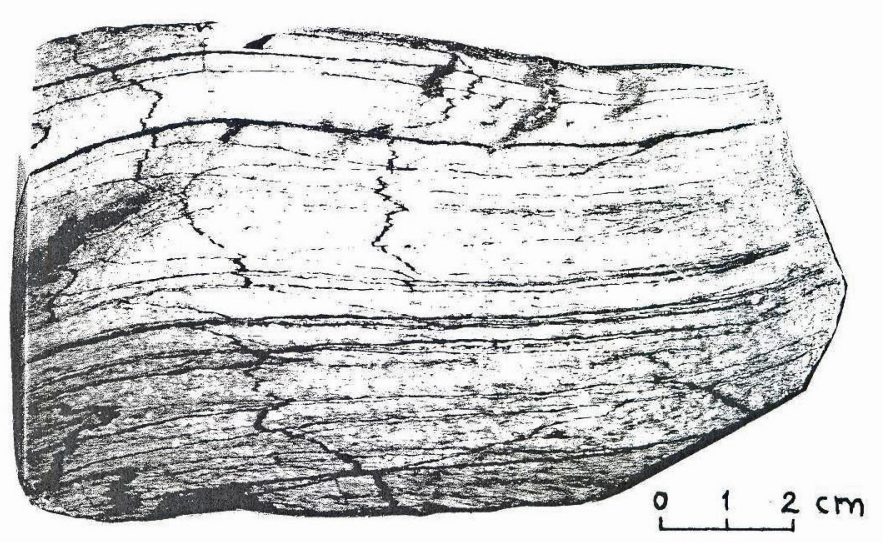

Fig. 18- "Fenito". A estruture orientade reflete a xistosidade da roche original. Foto de J. C. Nendes). 


\section{$4-$ Estruturas}

Os elementos estruturais observados objetivaran fornecer dados, que pudesson contribuir para o esclarecimento do mecanismo de colocacä́ do corpo magmático de Ipanema. Assin, as seguintes ostruturas foram estudades: h-xistosidade dos metassedimontos, B-acamamento e diáclases das rochas sedimentares, Crfalhas e D-diques de shonkonito-porfi ro.

\section{A - Xistosidade}

A direção da xistosidade dos metassedimentos é muito consistente - on média, $150 \mathrm{OE}$ - (en relação ao norte geográfico) e os mergulhos são próximos de vertical. (v. mapa goológico). Contudo, has proximidades das rochas alcalinas, os metassedimentos sc apresentam amarrotados e fraturados (v. figura 7), indicando o esfôrço exercido pelo magma contra as rochas encaixantes.

\section{B - Acarnamento}

No mapa geológico registramos algumas nedidas de direção e der ulho das camadas do Grupo Tubarão. 0 maior número de obscrvações estão ao norte e nordeste da área das rochas alcalinas; na região sul, onde os afloramentos escasseiam, não há medidas assinaladas. Ho flanco leste da serra de Areçoiaba, é perfoitamonte visívol, no campo, a inclinação das canadas para leste (v. fig. Il),

is direções das camadas varien, cono se depreende, por exemplo, das medidas registradas, próximas ao córrego da onça ( $v$. mpa), a nordeste da pedreira de celcário. da Cia. de Cimonto Ipanena ; os runos dos mergulhos dessas ca madas, porém, são mais commento opostos à área da intrusão alcalina. Os âmgulos de merguliho são da orden de 109 a 150 (fig. 12), nas proximicados da área das rochas alcalinas e diminuem à nedida que se afasta desta área. 
Sssa atitude das canadas sedimentares parece es tar ligada ao tectonismo provocado pela intrusão, pois, normalinente, as camedas do Grupo Tubarão apresentain mergulho regional muito pequeno (da orden de 10 a $1030^{\prime}$ para oeste), conquanto, na área de Ipanema, se encontrem inergulhos superiores a 100 , con rumos diversos.

Outro dado digno de interêsse, relacionado com - tectonismo dá área, é a inclinação da superfície do embasamento cristalino. A presença de algumas manchas de sedimen tos que remanesceram isoladamente sôbre o cristalino, preservando-the a supcrfície original, e ainda os dados de sondagens (tabela l) pernitiran avaliar a inclinação do embasamento cristalino, em direções dispostas radialnente ao redor da intrusão. Os valores obtidos variaram de 100 a 200 , o que demonstra estar essa superfície com inclinação da wesma ordem de grandeza das camadas sobrepostas.

\section{Camada-guia}

A existência de una cañada-guia entre as rochas encaixantes, cuja atitude pudesse ser conhecida cm vários pontos, contribuiria substancialmente para elucider algumas das questões que constituem os objetivos do presente trabalho. Infelizmente esta possibilidade é remota para oGrú po Tubarão. Wo entanto, uma ceinada de varvito poderia, eventualmente, constituir um horizonte único, pelo nenos em pequenas áreas. Nossas observaçõos de campo parecem indicar não mais que una camada dessa rocha, de pouca espessura. Knecht (1960, p. 76) menciona as diferenças de nível em que se encontram camadas do varvito como prova dos folhamentos que ocorreram na área de Ipanema. Astes fatos levaram-nos a consi derar, com as devidas reservas, o varvito como provável cama da-guia e, por isso, fizemos constar as altitudes de seus a floramentos no napa geológico. O maior número de observações está a norte e a noroeste da ćrea do mapa.

Como pode ser notado, com exceção do varvito, muito perturbado, que capeia o sill de shonkinitomṕrfirono 
"Corte Grande" (fig. 15), em todos os dema1s afloramentos não encontramos diferença de elevação maior que 40 metros;as altitudes do varvito estão entre 560 e 600 metros. Não queremos generalizar, mas acreditamos que em áreas restritas co mo a do quadrante noroeste do mapa, deve tratar-se de um nes mo horizonte de varvito. Assim sendo, o fato das diferenças de altitudes dêsse horizonte não ultrapassarem $40 \mathrm{~m}$ parece indicar que a colocaçäo do magma alcalino foi acompanhado tão-sómente de pequenos falhamentos, pelo menos naquele setor da serra de Araçoiaba.

\section{C- Diáclases}

As diáclases são as estruturas responsáveis er parte pelo aspecto morfológico espetacular con que se apresentam as rochas sedimentares do Grupo Tubarão em vários pontos ao redor da serra de Araçolaba, particularmente em seu rlanco oriental (fig. II). São essencialmente diáclases de tens̃o.

O fato dessas fraturas não terem sido preench das em grandes proporções por material magmático pode ser explicado, levando-se en conta, em prineiro lugar, que entre as rochas sedimentares alculinas estão situadas as ro chas do embasamento cristalino, cujo comportamento é diferente das sedimeritares em relação a fraturamento; em segun do lugar, que o material magmótico que eventualmente atravessou o embasanento, atingindo as rochas sedimentares, intercalou-se, preferencialinente, ao longo de suas camadas sob a forma de sills. Una prova que temos dessa preferência do nagma pelo acamamento são os diversos corpos do rochas alcalinas intercalados ontro os sedinentas, conforme indican as sondagens feitas a regiăo ce Ipcnema (v, tabela 1 ).

Na Éroa estudcids ocorren dois conjuntos de diá clases no Grupo mbraño con direcöos perpendiculares entre si. Como èsses conjuntos provìvelmente se formaram no tempo da intrusão, podenos denoninámlos un sistema de diáclases. 
En quaso todos os arioranentos pôde-se verificar êsse sistema de fraturas (fig. 13).

o núnero de medidas das diroções o rergutho das dićclascs, foltas dirotanente nos afloronentos, não é suficicnte para una análiso cstatística das direcöes preferenciais, mas sugere que un coniunto dessas dićcleses se dispöe. radialmente a rodor de intrusão e o outro, concêntriccmente. No setor da fotogrefia cérea visto na rig. 4 pode-se notar a disposição radiel dos traços das diéclases naquela área. A fig. Il nostra, citro outros asjectos, como se apresentan no terreno ostas dićclases abertas pela erosão atual.

Pudcuos vorificar, pelo cxare das fotografias aćreas, que as direções des dićclases radiais convergen, com pequena dispersão, pare o contro goonétrico da órea das rochas alcolinas ( $v$, fig, 6). O foco jrincipal do irradiação dos esforços cxorcidos polo negra intrusivo deve possivelmen te oncontrar-so num ponto verticalnento abairo do centro geo métrico nencionado. Un núnero estatisticenento representativo de nodidas das atitudos das díclases concêntricas, en tô da a árce quo circunda as intrusivas, poderia precisar meIhor a cxata posição esnacial do foco dos esforços exorctdos pelo magna. As pouccs nodidas eretuedas, no entanto, mos tran mersulhos muito accotuados, próximos de verticel, o que sugcro que o foco principal dos esforços deve ester locallzado a profundidade da orcen do alguns quilonotros.

\section{D - Folihamontos}

INão verificanos diretancnto no campo qualquer Palha de erondo rojeito. O gronito intensamento cisalnado da pedrcire locelizada no bairro do Iporó e ume zone brccha 3a no arenito do Grupo Tubarño são duas provas dirotes mais valjosas quo pudowos rounir durento o levantemcnto scolócico da troa. A roche brochede foi oncontrcde ao sul da ́rroa da intzusão alcolina, no local donominedo Pingo D'figua, num bloco do arenito intonscwonto silicificado. A brocha (fig.14) 
contém fragraentos angulosos de arenito do Grupo Tubarão, de dimensões contimétricns, cinentados por quartzo e un mineral esverdecido (epídoto?).

o estudo estereoscópico de fotografias aéreas, por cutro lado, permitiu distinguir feições morfológicas que podem ser correlacionadas a zonos de falhamentos. As linhas de falhas mais províveis estão assinoladas no mapa geológico. Exemplo notóvel de feição linear é o córrego da Onça (v. mapa), que se estendo por alguns quilônetros, na direção NE-SW. Afloramentos de varvitos em ambos os lados dêsse córrego apresentam desnível de quase 40 metros. Pequenas faIhas observadas no calcário da pedreira da Cia. de Cimento Ipanema seguem a mesma direção do córrego da onça.

Outra possível zona de falhamentos tem direção NW-SE (v. mapa), estendendo-se da pedreira de calcŕrio acina citada até o bairro de Araçciaba. Con exceção do corpo isola do, de anfibolito, o erabasanento cristalino não aflora a nor deste dessa linha. De fato, em gronde parte dêsse setor da região de Ipanema, o embasamento se encontra coberto polo Grú po Tubarão. Os dades de sonảagens descritos na tabela 1, per niton verificar o perfil assumido pelo enbasomento ao long de três pontos situados en linha aproximadanente reta(v.mapa):

(I) altitude do embasamento, no loito do córrego da onça: $650 \mathrm{~m}$.

(2) idem, na sondagen II (tabela 1): $514 \mathrm{~m}$

(3) idem, na sondigem I (tabela 1 ): $420 \mathrm{~m}$ As posiçõos dessas scindagens estão assinaladas no mapa goológico. Cono se nota, do ponto (1) 20 ponto (3), o cmbasomento aprosenta desnível de $230 \mathrm{~m}$, eri $4 \mathrm{knl}$ de distôncia. Esse fato parece deconstrar que, se houvo falhomentos, form de pequeno rejeito e possivelnente escrionados, conforme previra Leinz (1940, p. 11).

Outros fatos que ainda podemos acrescentar a faver da provável cxistência da zona de falhanento NW-SE sĩo: a nudança brusca do rolêvo que se pera no alto da ser ru de Araçcicba, a disposição linear do córrego a oeste do bairro de Lraçolaba e o excepcional mer butho de 702 , que apre sentam siltitos argilosos, às margens do citado córrego. 
Parece-nos que dois sistemas de falhas cortan as r chas encaixantes da intrusão alcalina de Ipanema. Um sistema, con diroção NE, possivelmonte controlado pela xisto sidade e o outro, prodoninantonento $N$, desonvolvido perpendicular à xist sidade (v. mape goológjico).

\section{E - Diaues e sills de shonkinito-pórfiro}

SNo rclativamente poucas as ocorrencias conhecidas de diques e sills ligados 20 agmatisno alcalino de Ipanoma. A mais extensa exposição pode ser vista no corte da "cstrada para as ninas", na encosta sul do morro Grando. Nien cionado já por Derby (1891), tal sill aflora numa extensão de $300 \mathrm{~m}$, a longo da roforida estrada (v. mopa). I copeado por sedimentos vórvicos (fig. 15) muito perturbados, de colo ração esverdoada o ondurecidos graças ఏ ação do magna. No in terior do corpo de shonkinito-pórfiro encontram-se fragmentos das rochas encaixantes (fig. 16), igualnente endurecidos.

As demis ocorrências regjistrodas no mapa geoló gico sño menores do que a citada e a mais distcnte localizase a cêrca de $5 \mathrm{kn}$ do centro da intrusão, no corte da estrada de ferro Sorocabana. Sc̃o conhecidas, no entanto, ocorrênclas dêsse tipo de recha, talvez ligadas ao nesmo magmatismo, en áreas afostades de algumas dezenas de quilônetros do centro da intrus̃̃o de Ipanena. Haciel e Guinorães (1955) descre vem un dique de shonkinito-póríro no município de Tatuí, la calizado a $15 \mathrm{kn}$ da intrusão de Ipanema. Asse dique, encaixa do nos sedimentos do Grupo Tubarão, é vertical, ton direção N70w e 20-50 metros de espessura. Knecht (1960, p. 72) cita uma corrência de rocha alcalina no bairro dos Soares, aunicípio de Piedade, a uns $40 \mathrm{~km} a \mathrm{SE}$ de serra de Araçoiaba. Se sundo tal Autor, trata-se taibén de un corpo do shonkinito pórfiro, macroscópicamente senelhante ao de Ipanera. 


\section{5 - Considoracões gerais}

\section{a) mecanisno da intrusão}

A intrusão alcalina de Ipanema parece ter sido essencialmente do tipo do injecõo forcada. Loinz (1940, pp. 11 e 15) aprosents un esbôço tectônico da região, no qual mostra o socrguinento do teto das encrixantes graças a ação do nagma. Admite (idem, pp. 26-27), justificando o caráter híbrido de algumas rochas alcalinas, ter o magma assimilado parte das encrixantes. Martin ot alt. (1960, p. 173) mencionam Ipanema cono exemplo de intrusõo alcalina em que não houve abatimento da parte central do teto, como soe acontecer no naicria das intrusões dêsse tipo, mas, apenas arqueamento.

Os dados que coletamos no levantanento goológico parecen confirmar inteiromento esta interprotação.

De acôrdo con as considerações feitas à página 4 , as rochas do ombasamonto cristalino, que afloram na serra de Araçoicba, estariam deslocadas verticalmente até 500 metros do sua posição normal. Poder-se-ia ponsar, como primeira hipótose, que a serra existisse como feição norfoIógica (nunatak) da suporílicie trabalhada pela glaciação per no-carbonífera, sondo mera coincidência a presença da intrusão alcalina. I difícil, no entanto, conccber que a ação orosiva da glaciação pudesse ter poupado área tão restrita cono a da serra do Araçoiaba, esculpindo do sou redor deşníveis até $500 \mathrm{~m}$, pois, as rochas do embasmento cristalino que afloran no tôpo da sorra (granitos o xistos) não apresentan características de mior rosistência ì orosão.

A inclinação da superfícte topográfica do enbasamento para fora da intrusão alcalina, bem como das camadas do Grupo Tubarão, constitui a prova nais segura a favor da hipótese de injeç̃o forcada do magna, con consequente arquea mento do teto das encaixantes.

o fato de não ter havido subsidência da parte 
contral da intrusão se dovo provìvolmento ao não c xtravasazento do magna. O Ponômeno Iimitou-se ̀े formeçẽo do rochas plutônicas, som possar ìs vulcênicas (Loinz, 1940, p. 11 ). Bouve o soerguimento do teto, ass o processo geológico nẽ.o ovolutu ató a fomaçẽo co estrutures do colepso.

\section{$* * * * * * * * *$}

o ajuste das rochas onceixantos, cm conscqü̂̉ncia dos esforços sofricos, fêz-se principalnente por neio de frcturas (diáclases o falhas). As dićclases foman dois conjuntos, un radial, outro, concêntrico. As falhas, dispostas escalonadamente, possuom pequeno rejeito, de orden de metros ou de poucas dezenas de netros. A superfícic do embasanento cristalino, exposto co redor de serra de Araçoiaba, apresenta inclinação suave para îra da intrusão, não havondo indicoção alsume do ocorrôncia de felhes de gronde rejeito. Além disso, a pequena oscilação no nívol do horizonte de varvito sugcre soerguimonto unirorme des rochas enccixantos. Parece fazer cxceção aponas o sotor $\mathrm{E}-\mathrm{NE}$ ( $v$. Mapa geológico). Nossa área, o embasamento cristalino soireu levantemento rolativo monos intonso que nas domais. 0 poço I (tabela 1 ) indice que o embesanento cristalino se encontra a 420 netros do altitude, enquanto que, no ponto diametralmento oposto en relação ao contro da intruss̃o, o ombasamonto aflore a cếrca de 600 metros de altitude.

\section{b) Forna do corpo intrusivo}

Bascendo-se nos estudos geológicos de Knecht (1930) e om observeções própries, Loracs(1938, fôlha 3) a.pre sontou una secẹ̃̃o foolósica esquonética da sorre de Lrç̧oiaba cn quo mostra as rolaçöes entre as rochas intrusivas a as cnccixcintes. Segundo êsse Autor (p. 3 e 13), o magno se dis porsou nes roches checixentes, desenvolvendo corpos tabularos o Ionticularos, preforenciclmonto ao longo dos sous planos do xistosidede. Os actassodinontos quo soperan os vários corpos do rochas alcelines ș̃o doscritos polo roforido Autor 
(p. 4 e fôlha 3) como "xistos injetados por rochas nefelínicas".

As observações geológicas que pudemos coletar na área da intrusão alcalina são condizentes coin a hipótese do citado Autor. De rato, encontramos muitos blocos de rochas encaixantes na área das roches alcalinas, a maioria das quais alteradas metassomaticamente (os "fenitos"). If possível quo muitas das rochas denominadas por Horaes (1938) como "xistos injetados por rochas nefelínicas" correspondam ao que descre vemos cono "fenitos".

0 fato de quase tôdas as jazidas de magnetita e apatita possuirem a forma de lentes alongadas na direção NESW (segundo mapa apresentido por Knecht, 1930), parece constituir a prova mais evidente do contrôle exercido pela xistosidade, sôbre o modo de intrusão do magma. E possível que o traçado do ribeirão do Ferro, dentro da ́́rea das rochas alcalinas (v. mapa geológico), seja um reflexo da imposição dessa estrutura dos metassedimentos.

$$
* * * * * * * *
$$

Os autores que trabalharam na região de Ipanema não fazem menção quanto à forma e as dimensões do corpo alcalino, ern profundicade. As observações geológicas, porém, justificam supor que a intrusão se amplia, em profundidade, ocupando maior b́rea horizontal que em superfície.

o abaulamonto das rochas encrixantes em consequência da intrusão magnática abrange área relativamente gran de. Hó pontos do embasamento cristalino afastados horizontal menie até $10 \mathrm{~km}$ (v. mapa geclógico), enquanto que o diâmetro da área das rochas alcalinas não ultrapassa $3 \mathrm{~km}$. lém disso, a crída da supcrfíeie do embasamento, bem como das rohas se dimentares sobrepostas, para for da área da intrusão, é mui to suave. Há, por conseguinte, um arqueamento muito amplo uns rochas encaixantes, quo só pcde ser explicado como conse cilente de esforços exercidos por un volume de rochas ífreis muito maior do que sugere a áree de aflcramento dessas ro- 
chas. Os diques de shonkinito-pórfiro, distantes até $5 \mathrm{~km}$ do centro da intrusão, constituem argumentos a favor dessa hipó tese.

Devemos lembrar também que a superfície topográ fica atual no alto da serra de Araçoiaba corresponde aproximadamente ao teto da intrusão alcalina, pois, no ponto culmi nante dessa serra $(967 \mathrm{~m})$, ainda estão presentes rochas sedi mentares. Isto expliccria o motivo de ser relativamente pequena a área de afloranento da intrusão alcalina. 


\section{IV - ESTUDOS GEOFISICOS}

As pesquisas geofísicas tiveram chas finalida des:

a) contribuir com novos dados para completar o quadro fornecido pelos estudos geológicos;

b) investigar as ocorrências de magnetita e apatita.

Três métodos foram empregados nestes levantamen tos: gravimetria, eletrorresistividade e magnetometria. Os instrumentos utilizados pertencem ao Departamento de Geologia e Paleontologia da Faculdade de Filosoria, Ciencias e Lê tras da Universidade de São Paulo.

As investigações gravimétricas e magnetométri cas não se restringiram apenas à região da serra de Araçoiaba. Para que se pudesse ter uma visão mais ampla da distribuição das anomalias regionais, tanto gravimétricas como mag néticas, tivemos que estender nosso campo de trabalho para rea ben maior, com cêrca de $2500 \mathrm{~km}^{2}$, linitada pelas cidades de Itu, Tictê, Itapetininga, Sarapuí e Sorocaba (v. fig. I).

\section{1 - Pesquisa pravimétrica}

Considerações genéricas sôbre o método gravinétrico foram feitas na publicação de Nollert, Bjbrnberg e Davino (1961). Aqui restringiremos nossas discussc̃es ao proble ma específico en estuco, dando maior ênfase à parte de inter pretação dos rervltacos.

A SinaIidade do nótodo de prospecção gravimétrica é procurar interprotew, em tôrmos geológicos, as anom malias observadas no compo Enritacional da Terra. Tais anomalzas existem sempro cue estruturas da crosta terrestre cau 
scm irregularidades laterais na distribuição das densidados. Era plenamente justificável a apliccção do métc do gravimétrico cono auxiliar no esclarccinento da forma e atitude da intrusão alcaline de Ipanema. Issa estrutura, em razão de sue densidade e tamaino, deveria apresentar anomalia positiva em rolação is rochas encaixantes.

\section{Procedimento de campo}

- trabalho de campo consistiu na observação da gravidade relativa em estações distribuídas, ao longo das es tradas de rodagen, com espeçanento variado, mas, en geral de 3 a $5 \mathrm{~km}$. Próximo à área da intrusão alcalina, a rêde de estações é nuito mais densa, sendo o espaçamento entre as mesmas de 0,5 a $1 \mathrm{~km}$.

o instrumento utilizado no levantamento foi o gravímetro Nyrgaard, descrito con pormenores no trabalho citado (Kollert et alt., 1961, pp. 72-74). o corte esquemático e o dispositivo fundamental do gravimetro poden ser vistos na fig. 19-A. A peça principal consiste de un pêndulo, prêso, en posição quase horizontal, a um fio de quartzo. Os valores relativos de gravidade sĩo obtidos a partir do ingulo de deflexão do pêndulo.

A fig. 20 reproduz os dedos de campo e os cálculos foitos em un dia de trabalho. As leituras do gratinetro (registradas na caderneta de campo) são transformadas em valores de mgals e colocados em gráfico, em função do tempo. A prrtir dêsse gráfico, denoninado curva de deriva do gravímetro, obtén-se os valores relativos de gravidade observados en cada estaçño. Visto que êsses valores dependen de fatôres tais cono latitude e elevação da estação, topografia ao redor e efeitos das marés, é necessámio corrigir suas influências para que os valores resultantes reflitam apenas as distorções do campo gravitacional causadas pelas irregularidadades na distribuição das massas rochosas na cresta terrestre. 0 computo dessas comreçós esté exemplificado na fig.zo citada. São denoninades correçóes de latitude, ar-livre, 

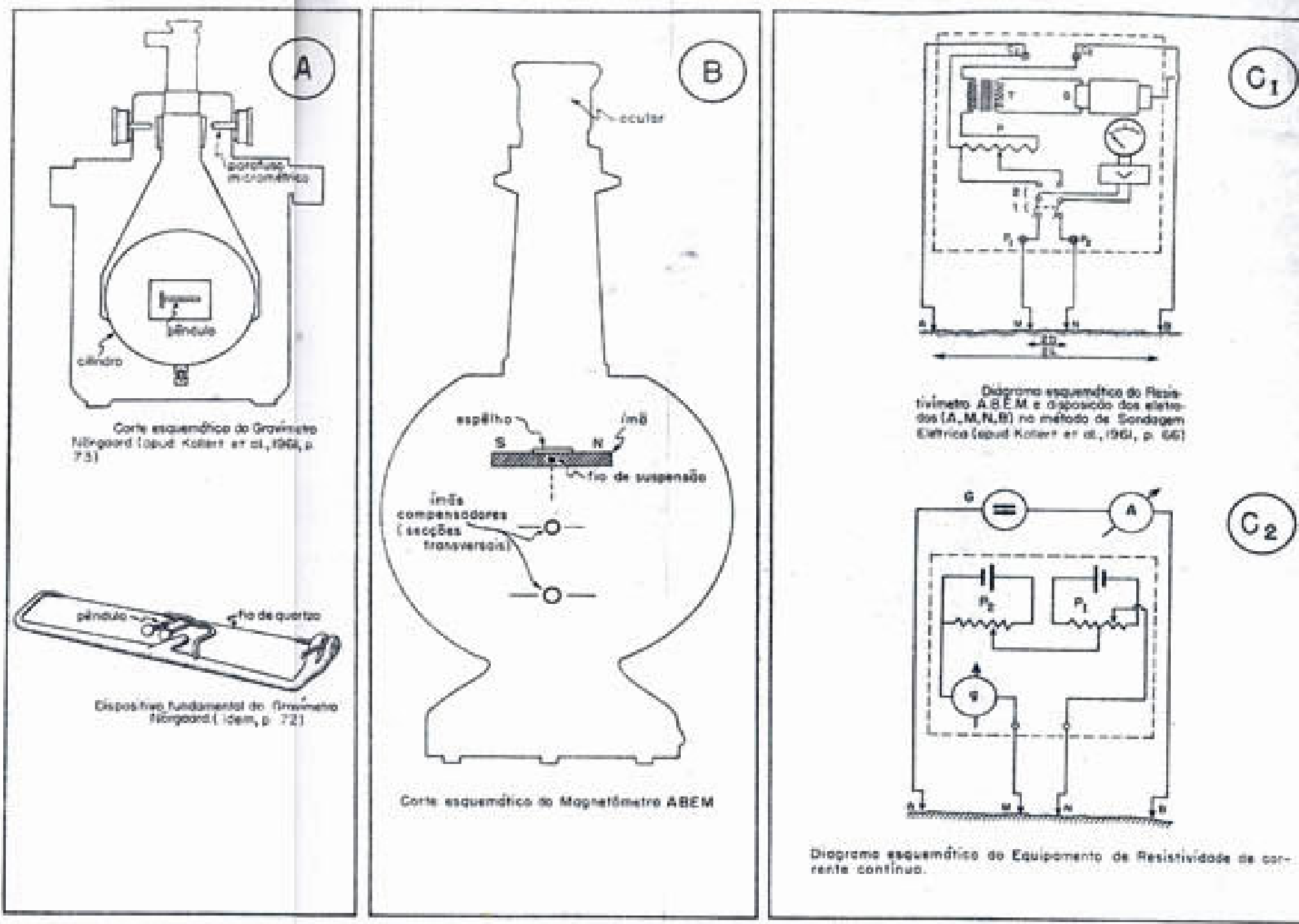

$\mathrm{C}_{2}$

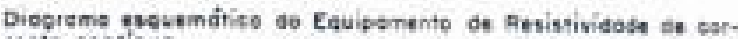
torite tontinus.

F1R. 19- Zsquetia dos instrumontos ut121zudos nos $16-$ vanteruentos georfsicos. 
Local boneme Dara $22-6-63$

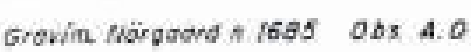

\begin{tabular}{|c|c|c|c|}
\hline$I$ & 2 & 3 & 4 \\
\hline$E x t$ & $\frac{7}{15}$ & abrits & $\begin{array}{l}\text { Drowdife } \\
\text { rel,- } \Delta 9_{1} \\
\text { moole. }\end{array}$ \\
\hline$p$ & $13 / 6$ & $3 a^{n t}$ & 41.3 \\
\hline 69 & 148 & $\mathrm{NO}^{20}$ & 497 \\
\hline$p$ & $1+3 / 6$, & $\mathrm{NO}^{-57}$ & 40.9 \\
\hline 69 & $19 \mathrm{~g}$ & $N^{2} \div$ & 48.4 \\
\hline 70 & 1483 & $n^{09}$ & 50.2 \\
\hline : & & : & : \\
\hline : & & : & : \\
\hline t & & , & + \\
\hline 75 & $\frac{214}{210}$ & $16^{4}$ & 17.2 \\
\hline$\rho$ & 2116 & $f z^{41}$ & 36.2 \\
\hline
\end{tabular}

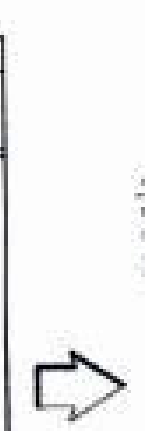

Estag os:

Alfitedes relotives Aitifuder $1 \mathrm{~m}(\mathrm{~m})$ Letifudes resatives $\mid \mathrm{k} \cdot \mathrm{m})$

\begin{tabular}{|c|c|c|c|c|}
\hline$\rho$ & 69 & 70 & $1+ \pm \pm$ & 75 \\
\hline+420 & -18.0 & -21.1 &.+++ & +72.6 \\
\hline $0.8 B^{5}$ & $145^{5}$ & $2.21^{5}$ &...+ & $8.40^{-N}$ \\
\hline
\end{tabular}

\begin{tabular}{|c|c|c|c|c|c|c|}
\hline$t$ & 5 & 6 & 7 & $\theta$ & 9 & 10 \\
\hline \multirow{2}{*}{ Est: } & \multirow{2}{*}{$\Delta g$} & \multicolumn{4}{|c|}{ corregoes } & \multirow{2}{*}{$\underset{\text { Findl }}{\Delta \mathrm{g}}$} \\
\hline & & Lot. & or-fiure & Bouguar & Topog & \\
\hline$p^{4}$ & -15.4 & -0.5 & +127 & -3.8 & & -7.0 \\
\hline 69 & -6.8 & -0.9 & -5.6 & +1.7 & I & $-m .6$ \\
\hline 70 & -5.9 & -13 & -6.5 & +19 & i & $-11,8$ \\
\hline + & - & • & • & * & 象 & . \\
\hline - & - & • & + & $*$ & - & - \\
\hline - & * & - & + & 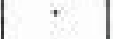 & $\infty$ & * \\
\hline * & * & * & + & + & - & $\cdot$ \\
\hline • & • & + & - & + & $<$ & + \\
\hline 79 & -22.3 & +2.0 & +12.0 & -36 & 1 & -11.9 \\
\hline 80 & -259 & +92 & -49 & +1.4 & & -20.2 \\
\hline
\end{tabular}

[Na O valar ate gravidade de $P(\mathrm{Ag}=-15-4)$ d relativo oo veler arbitróno, terc, atribuído ì ustaçảe na se de da Fax Ipaneme.

15e. 20- Dados to einpo, curvis de dorlva e fólla de chlatio so trubetho be eravinetris de un dis. 
"Bouguer", topográfica. En geral, não so corrige os efeitos das marés, por seren nuito pequenos. Em nosso trabalho năo corrigimos tambén o efoito da topografia ao redor de cada es tação, prineiro por não existirem mapas plano-altinćtricos a dequados e, segundo, porque tais corroções são desprezívels ne área investigada, en rolcção à precisão esperada para os resultados gravimétricos.

Para estação de referência, isto é, em relação gravidade observados, foi escolhida aquela situada na cidade de Itu. A esta estação foi atribuído arbitràrianente o va Ior de gravidade zero.

As alturas relativas das estações de gravinetria foram obtidas, scmpre que possível, a partir das referências de nível, existentes ao longo das rodovias (Talibert1 et alt. , 1962). En grande parte, porén, foran estabeleci das por nivelamento barométrico, usando-se dois altínetros "Wallace e Tiernan", segundo o método de una base (Mattos, 1955, pp. 181-182). A precisão das medidas obtidas pelo processo barométrico foi, para algunas estações, melhor que 0,5 metro e, em média, o êrro não ultrapassou 2 metros.

\section{A - Mana gravirétrico "Bouguer"}

A fig. 21 representa o mapa das anomalias gravi métricas "Bouguer". A precisão dos valores é da order de 1
ngal.

ronforme podenos verificar, o mapa apresenta altos e baixos gravinétricos que se sucedem suavenente. Destacam se as seguintes anomalias, que designaros com o nome de local nais próximos:

1 - os altos gravimétricos de Ipanema, Pôrto $F_{\underline{e}}$ Iiz, Tietê - Cesário Lange o Tatuí; 2 - os baixos gravinétricos de Boituva, Itapet 1 
Fig. 2l- Mapa Gravimétrico "Bouguer". Não estão representedas as estacõos próximas à intrusão alcelina. 


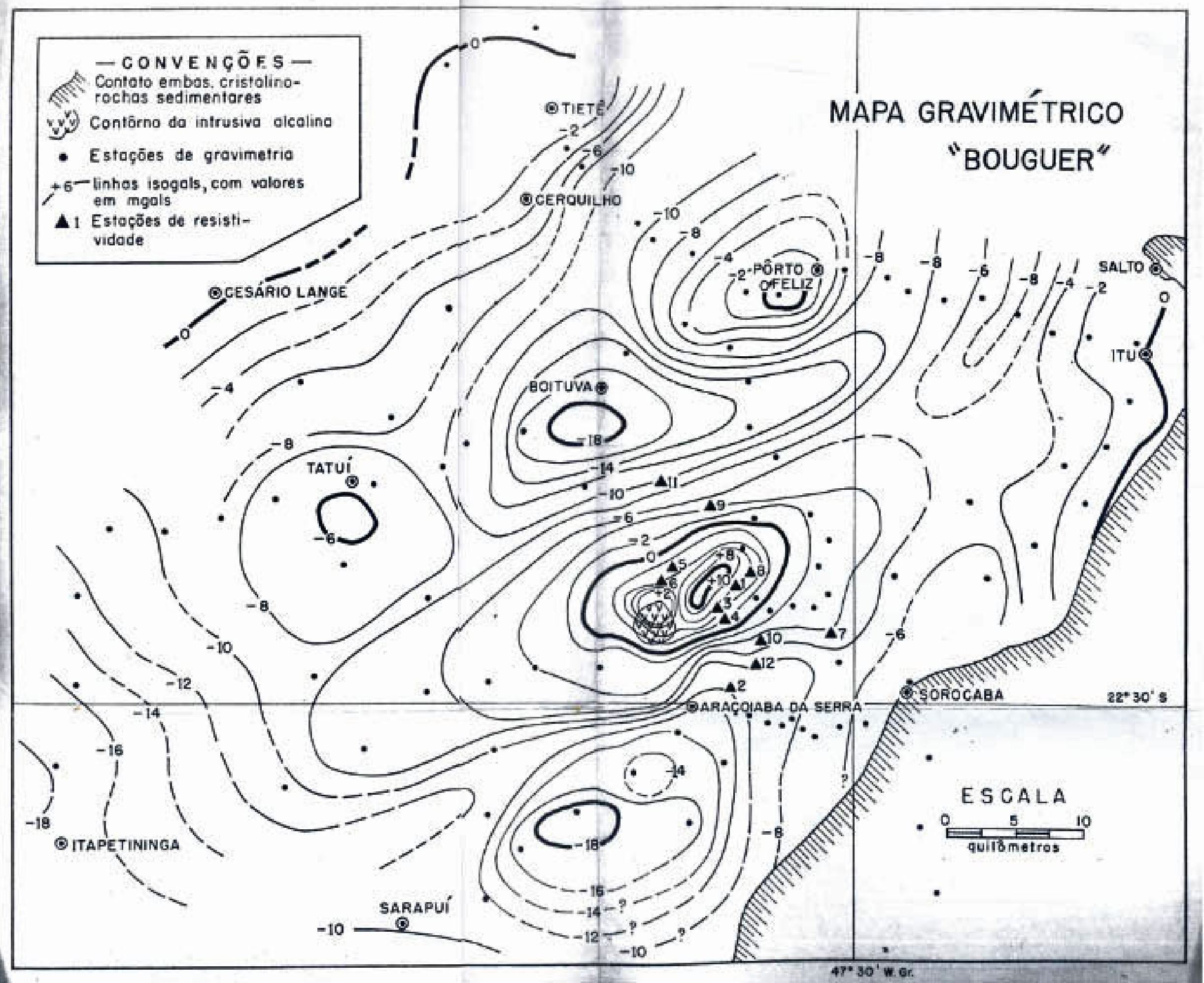


ninga, nordeste de Sarapuí e oeste de Itu.

A anomaita de Ipanoma se sobressai por atingir valores muito altos (lo mgals) en relação às outras anomalias ao redor (Bottura, por exemplo, com - 18 mgals), Devese também notar sua forma alongada na direção INE-.SW. Os valo res crescen en direģo á intrusăo de Ipanema, mas, o náximo atingido, +lu ngals, nä́o se situa sôbre a área de afloramento das rochas alcalinas; nesta, ao contrário, existo mesmo un decréscimo dos valores de gravidade. Isto pode ser explicado, em parte, levando-se en consideração que o nível em re lação ao qual foran referidos os valores de gravidade corta a serra de Araçoiaba na altitude de 594 metros (altitude de referência tomada en Itu). Dêsse modo, o mapa gravimétrico reflete apenas as estruturas rochosas situadas abaixo daquele nível, deixando de registrar o efeito das rochas alcalinas e das encaixantes, situadas acima daquele nível.

\section{Análise do mapa gravimétrico "Bouguer"}

Conforme afirmamos anteriormente (p.27), as anomalias gravimétricas são causadas por irregularidades na distribuição lateral das densidades dos materiais da crosta terrestre. Em nossa área de investigação, as fontes dessas variações na densidade são:

a) O mergulho regional da superfície do embasa mento cristalino;

b) variações litológicas e estruturais no enbasamento;

c) corpos ígneos intrusivos no Grupo Tubarão;

d) variações litológicas e estruturais, no sentido horizontal (con consequentes variações nas densidades), des rochas do Grupo Tubarão;

e) irreguiaridades topográficas na superfície to embasamento cristalino. 
na interpretação dos resultados da gravinetria constam da tabela 2.

Tabela 2 - Densidade de algumas rochas relacionadas ¿ geologia da região de Ipanema

\begin{tabular}{|c|c|c|}
\hline Rochas & Localidade & $\begin{array}{l}\text { Densidade } \\
\text { amostra } \\
\qquad \mathrm{g} / \mathrm{cm}^{\text {da }} 3^{\text {éca }}\end{array}$ \\
\hline Granito & Salto & 2,63 \\
\hline Filito & $\begin{array}{l}\text { Km } 116 \text { da estrada } \\
\text { Sorocaba-Piedade }\end{array}$ & 2,69 \\
\hline Calcário & Ipanema & 2,73 \\
\hline Anfibolito & Araçoiaba da serra & 3,00 \\
\hline Tilito & Ipanema & 2,56 \\
\hline Arenito & Idem & 2,24 \\
\hline Arenito & Iden & 2,28 \\
\hline Arent to & Idem & 2,26 \\
\hline siltito & $\begin{array}{l}\text { Estrada Tietê-Pôr- } \\
\text { to Feliz, Kn 152, } \\
\text { antigo }\end{array}$ & 2,19 \\
\hline Varvito & Itu & 2,33 \\
\hline $\begin{array}{l}\text { "Fenito", com } \\
\text { pouca egirina }\end{array}$ & Ipanema & 2,65 \\
\hline $\begin{array}{l}\text { Ortoclásio- } \\
\text { egirinito (?) }\end{array}$ & Idem & 2,79 \\
\hline $\begin{array}{l}\text { Shonkinito- } \\
\text { pórfiro }\end{array}$ & Idem & 2,79 \\
\hline
\end{tabular}

Baseancio-se, não apenas nesta tabela, mas em es tatísticas feitas con centenas de determinações ( Dobrin, 
1952, pp. 90-92), podenos considerar que, em média, as densidades das rochas relacionadas às anomalias supramencionadas crescem na seguinte sequência:

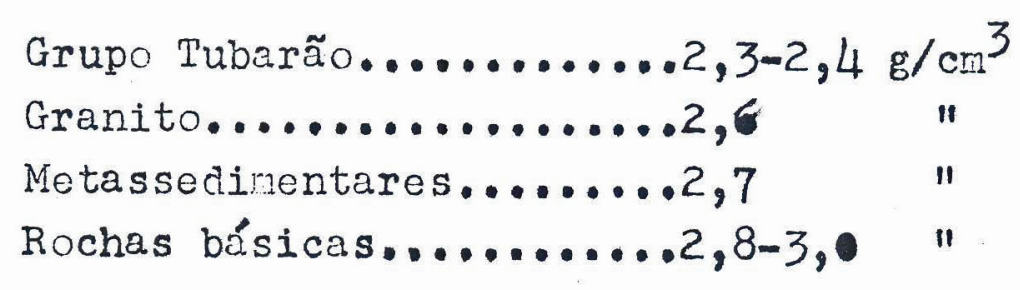

Como o mapa gravimétrico "Bouguer" é o reflexo da contribuição de tôdas as fontes de ancralias citadas, sua análise e interpretação en têrmos geclógicos não é tarefa fácil. Cumpre, no entanto, lembrar que anonalias causadas pelo mergulho regional da superfície do eubasanento e por suas variações litológlcas e estruturais tên formas suaves e amplas, ern contraposição àquelas cujas causas são as estruturas pouco profundas e, corparativamente, de menor volume. As primeiras são denominadas anomalias regionais em oposição às segundas, de caráter mais local, chamadas res1duais.

Cono geralmente estanos interessados mais nas anonalias gravimétricas residuais que nas regionais, reconhecer e isolar estas últimas do mapa gravimétrico "Bouguer" é o primeiro passo para a interpretação.

As anomalias gravimétricas regionais na área investigada são causadas principalmente pelos ítens (a) e (b) anteriormente citados.

Os corpos Íneos intrusivos no Grupo Tubarão são os principais responsáveis pelas anomalias locais. Even tualmente, alguns corpos de diabŕsio, dadas suas dimensões e posição, psden causar distorções no campo gravitacional, que se enquadran nos padrões das anomalias regionais.

As fontes de anomalias descritas nos ítens (d) e (e), para os propósitos e a precisão dos regultados da gravimetria, são de importância secundária no presente trabalho. 


\section{B - Mapa de gravidade residual}

Subtraindo-se do napa gravinétrico "Bouguer" (fig. 2l) as anomalias recionais, obtér-se o rapa de gravidade residual (fig. 22). Esse mapa mostra as distorções da gravidade causadas pelas estruturas locais.

A técnica enpregada para isolar a gravidade re sidual foi aquela preconizada por Griffin (1949, pp.39-59). Consiste en tirar a nédia aritnética dos valores de gravida de dos vértices de un polígono regular, convenientemente es colnido, cujo centro se situa no ponto on que se deseja a gravidade residual. A gravidade "Bouguer" no ponto central dêsse polígono menos a média da gravidade dos vértices dá a gravidade residual. Em nosso caso, utilizamo-nos de un hexágono regular cujos vértices distan $5 \mathrm{~km}$ do centro. A escolha dessa figura unitária baseou-se no exane preliminar do mapa gravinétrico.

No mapa residual ( $v \cdot f i g .22$ ) ressaltan-se dois altos gravinétricos, que passamos a denoninar:

1) alto gravimétrico de Ipanema

2) alto gravinétrico de Pôrto Feliz

Análise e interpretacão do napa de gravidade residual

Vamos analisar apenas o alto gravimétrico de Ipanema ( $v$. fig. 22). Trata-so de una anomalia de forma aproxinadamente elf́ptica, com Iinhas isogals alongadas na direção NE-SW, con cêrca de $50 \mathrm{~km}$ de comprinento, e até $15 \mathrm{~km}$ de Iargura. O náximo gravimétrico não está diretamente sôbre a área de afloramento da intrusão alcalina, mas, a leste, nas proximidades da sede da Fazonda Iponema.

Cono os valores de gravidade crescem en direção à serra de Araçoiaba, que ocupa priticamente o centro da anomalia, ó razoável supor que esta anomalia, en tôda sua extensäo, esteja relacionada no mesmo fenômeno geológico responstivel pela existôncia da serra. Assim sendo, o nagna que 


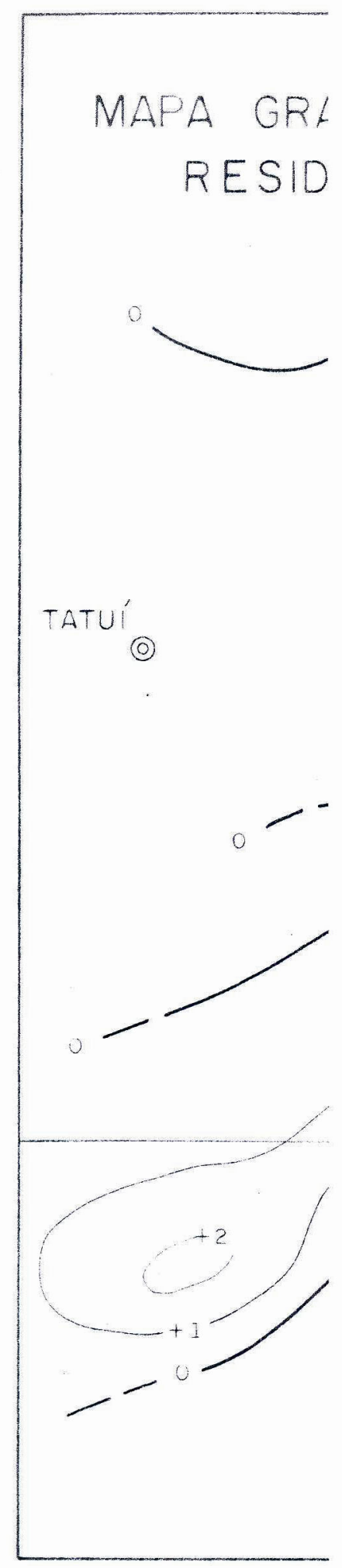

Fig. 22- Mapa gravimétrico residual. Observar a forma alongada na direção NE-SW da "anomalia gravimétrica de Ipanema". 


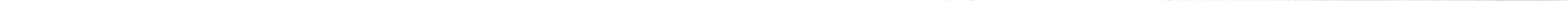


deu origen às rochas alcalinas de Ipanema, deve ter penetrado ao longo da faixa de direção NE-SW, conforme sugeren as linhas isogals fechadas, que contornam a região de Ipanema. Evidências geológicas desta extonsão alcançada pelo magma são os diques e s1lls de shonkinito-pórfiro que ocorrem ao redor da intrusão alcalina. De modo especial, o dique de shon kinito-pórfiro que ocorre no bairro de Congonhal (qunicípio de Tatur), a $15 \mathrm{~km}$ de Ipanema, en vista dos resultados do le vantamento gravinétrico, pode ser con mais certeza relacionado à intrusão de Ipanema.

Devenos observar que a anonalia gravinétrica de Ipanema é alongada na nesna direção das estruturas regionais do embasamento cristalino. A xistosidade dos metassedimentos na serra de Araçoiaba tem direção média N50E. E possível que, em profundidade, o magna tenha ocupado espaço, preferencialmente, ao longo dos planos de xistosidade, o que ven reforçar a argumentação a favor da hipótese feita, a partir de ob scrvaçõos geológicas, quanto ao mecanismo e a forma da intrusão (, p. 22).

Não podenos precisar com segurança a que profun didade podem ser encontradas rochas resultantes da intrusão nagmática. Aplicando-se, porém, a regra da meia-largura, verifica-se que os contros das massas causadoras das anomalias gravimétricas se encontran a quilônetros de profundidade.Tan to para NE como para SW da serra de Araçoiaba, hó indicação de progressivo aumento dessa profundidade.

\section{2 - Investigacão pelo nétodo de eletrorresistividade}

0 método de eletrorresistividade foi aplicado em Ipanena con a finalidade de determinar a atitude do enbasamento cristalino en pontos convenientenente escolhidos na ám rea dos sedimentos.

Estas determinações foram feitas pelo método da 
sondagem elétrica, um dos procedimentos do método de eletrorresistividade. Os princípios dêsse método, o procedimento de campo e modo de interpretar os resultados estão descritos na publicação de Kollert et alt. (1961, pp. 64 a 69).

As medidas foran realizadas con o resistivímetro ABEM-tipo 766 ( $\mathrm{fig} .19 \mathrm{C}-1$ ) e con o equipamento de corren te contínua ( $\mathrm{fig}$. 19C-2). O primeiro foi descrito na publica ção citada (Kollert et alt. 1961, pp. 66-69). Nas figuras 19C-1 e 19C-2, está indicada também a disposição dos eletro dos no terreno.

\section{$* * * * * * * * *$}

Os dados obtilos são colocados em gráficó, constituindo a curva de resistividade, cuja interpretação forne ce informes sôbre as condições geológicas de subsuperfície. A fig. 23 apresenta una das curvas de resistividade obtida na área de Ipancma, o sua interpretação, na forma de um perfil. Este perfil fornece a resistividade elétrica e a espessura de cada estrato elètricamente homogêneo, diretamente am baixo da estação de nedida. No nosso caso, só interessa a po sição do estrato de resistividade infinita, que corresponde ao erabasamento cristalino. No exemplo da fig. 23, o embasanento se encontra a 55,5 netros de profundidade. Os "estratos elétricos" acina do ombasanento correspondem aos sedimen tos do Grupo Tubarão, en diferentes condições: solo ( $0-3,7$ metros); sedimentos acina do nível hidrostático (3,7 - 18,7 netros) e sedimentos dentro da zona de saturacão $(18,7-55,5$ metros).

Foran executadas 12 sondagens elétricas cujas estações estão localizadas no mapa da fig. 21. Os resultados dessas medidas indicaran claranente que o embasamento crista lino se encontra en altitudes nais elevadas, nas proxinidades da intrusão alcalina, e, en altitudes mais baixas, à medida que se afasta da nesma. As determinações da profundidade do enbasamento na direção NW-SE (v. estações de resistividade 7, 8, 9 e 11 na fig. 2I) s ̃o apresentrdas na fig. 24. Nesta 


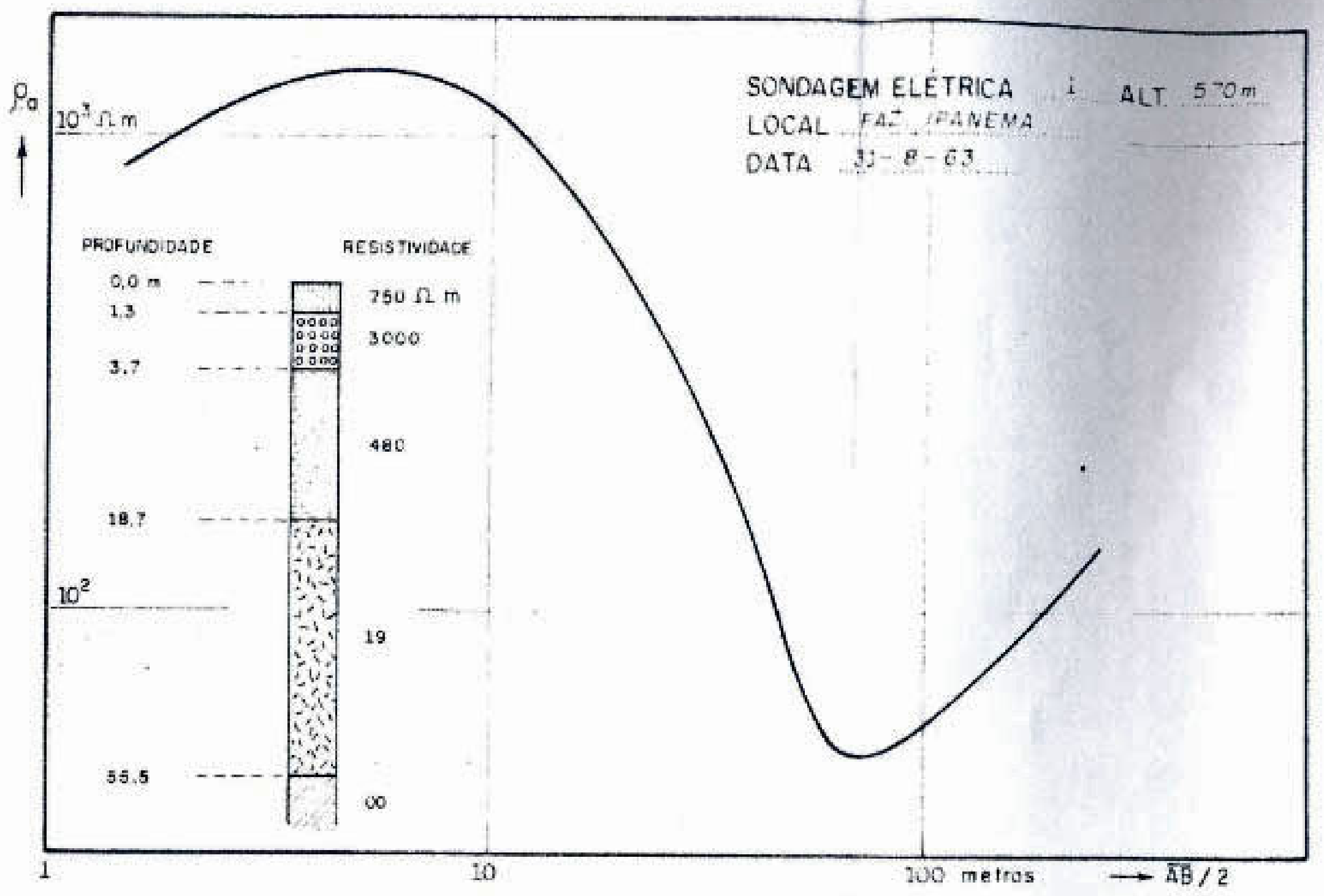

Fig. 23- Curva de resistividade obtida na estação 1.0 perfil fornece as espessuras (não em escala) e as resistividades de cada "camada" elètricemen te homogênea. 


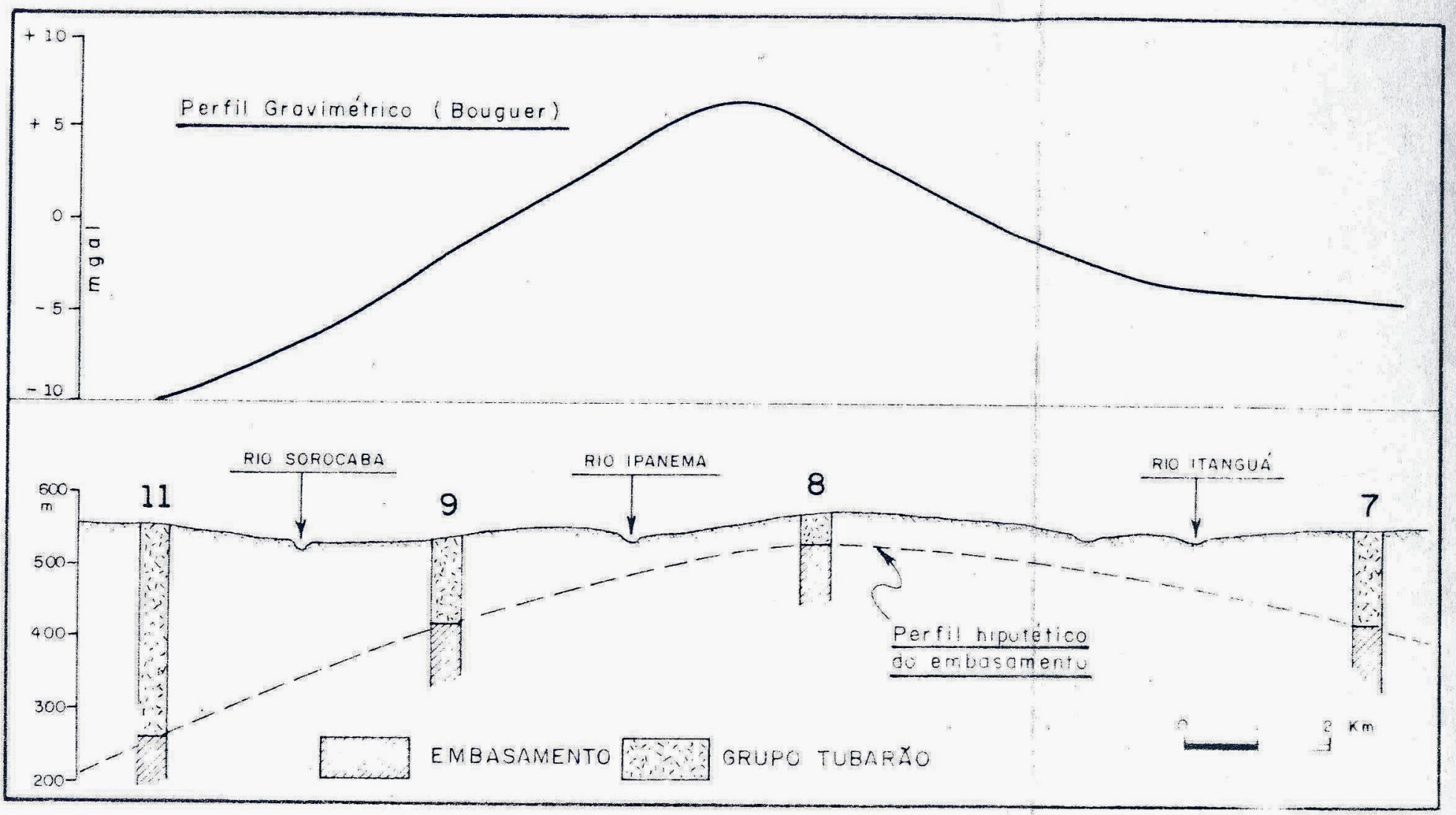

Fig. 24-Perfil hipotético do embasamento cristalino, de acôrdo com interpretação das "sondagens elétri cas". Notar como o perfil gravimétrico segue. configuração do embasamento. 
figura, fizemos constar também o perfil gravinétrico. E interessunte observar que a possível sonfiguração do embasanen to forma un arco justamente ao longo da direção en que se en contra o alto gravimétrico. Tal configuração do embasamento, no entanto, não pode ser a causa exclusiva dessa anomalia gravinétrica. Deve existin, em profundidade, urin corpo de den sidade relativanente alta, responsível por aquêle alto gravi métrico. A profundidade do centro dêsse corpo é da orden de $1 \mathrm{~km}$. Esta avaliaçäo foj. feita pela regra da meja-largura da anomalla gravimétrica.

\section{3 - Estudos magnetométricos}

E finalidade do método magnetométrico medir o campo magnético terrestre e interpretar as anomalias, nêle e xistentes, em têrmos da distribulção das estruturas geológicas. A intensidade e a forma dessas anomalias magnéticas dependem das dimensões da estrutura e das susceptibilidades magnéticas relativas das rochas.

A susceptibilidade magnética é a propriedade $f f$ sica dos minerais e das rochas de maior importância quando $8 \mathrm{e}$ considera o método magnétioo. Ela expressa a facilidade com que os materiais se tornam magnetizados quando se encontram em um campo magnético. Rochas com valores de susceptibilidade magnética relativamente maiores produzirão anomalias mais intensas no campo magnético terrestre. Não estamos considerando aqui, a contribuição, por vêzes grande, do magnetisno remanescente das rochas, adquirido à época de sua formação. Conhecendo-se as susceptibilidades Lngnóticas das rochas, podemos melhor orientar um trabalho de nagnejometria. Sabemos que esta propriedade, para un mesmo grupo de rochas, apresenta valores que variam entre largos limites. En média, no entanto, as rochas se alinham na seguinte sequência, en ordem crescente de susceptibilidade magnética 
(Birch et alt., 1949, p. 296):

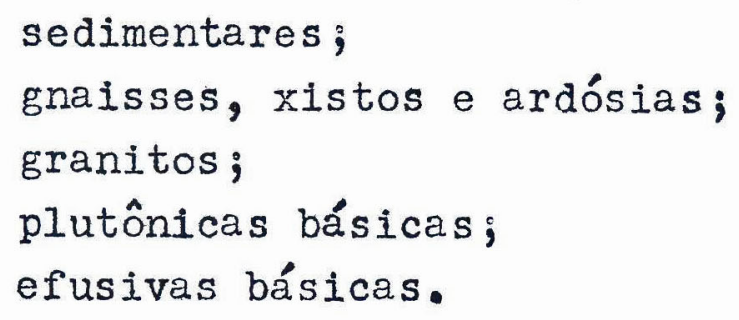

Em Ipanema, encontram-se rochas com susceptibilidades magnéticas relativas bem distintas - sedimentares, xistos, granitos e plutônicas básicas. Isto permitia supor prèviamente que os resultados de um levantamento magnetométrico pudessem revelar dados geológicos importantes de subsu perfície. A tabela 3 fornece as susceptibilidades magnéticas de algumas rochas relacionadas ao levantamento geológic• da região de Ipanema.

Tabela 3 - Susceptibilidades magnéticas de alguns materiais que interessam ao levantamento mag netomótrico da região de Ipanema

\begin{tabular}{|c|c|c|}
\hline Material & Local & $\mathrm{K} .10^{6}(*)$ \\
\hline F1lito & Ipanema: "estrada para as minas" & 10,7 \\
\hline Calcário & $\begin{array}{l}\text { Ipanema: pedreira da Cia, de Ci- } \\
\text { mento I panema. }\end{array}$ & 11,1 \\
\hline Granito & $\begin{array}{l}\text { Araçoiaba da Serra, bairro do I- } \\
\text { pero: pedreira }\end{array}$ & 416,1 \\
\hline Arenito & $\begin{array}{l}\text { Ipanema: testemunho da sondagem } \\
\text { feita no ribeirão do Ferro }\end{array}$ & 0,9 \\
\hline Varvito & Itu & 1,0 \\
\hline $\begin{array}{l}\text { "Fenito" com } \\
\text { pouca egirina }\end{array}$ & $\begin{array}{l}\text { Ipanema: amostra sôlta, encontra } \\
\text { da na área da intrusão alcalina }\end{array}$ & 61,6 \\
\hline $\begin{array}{l}\text { "Fenito" com } \\
\text { pouca egirina }\end{array}$ & $\begin{array}{l}\text { Ipanema: testenunho da sondagem } \\
\text { feita junto ao ribeirão do Ferro }\end{array}$ & 55,9 \\
\hline $\begin{array}{l}\text { Shonkinito- } \\
\text { pórfiro }\end{array}$ & $\begin{array}{l}\text { Ipanema: amostra sôlta, próxima } \\
\text { ao morro Grande }\end{array}$ & 477,0 \\
\hline Martita & Ipanema: morro de Ipanema & 209,4 \\
\hline
\end{tabular}

(*) Susceptibilidade magnética, em unidades C.G.S. 
As determinações foram efetuadas no "Cryogenic Thermometer", equipamento pertencente à Cadeira de Física do Estado Sólido, da Faculdade de Filosofia, Ciências e Lêtras, da U.S.P. Esse equipamento possui uma ponte de indução para as medidas da susceptibilidade nagnética. Um tubo de ensaio, que contém a amostra prèviamente noída, é introduzido no interior de uma bobina, que funciona como secundário de uma indução-mútua. O valor dessa última é altera do proporcionalmente à susceptibilidade magnética do material contido no tubo.

Em relação aos dados da tabela 3, cumpre assinalar que: 12) os valores da susceptibilidade magnética crescem na ordem normal esperada. São os menores nas rochas sedimentares, seguidos dos valores das metassedimentares e, finalmente, das rochas alcalinas; 20) o valor da susceptibilidade magnética do granito é relativamente alto; isto se deve, provàvelmente, ao seu conteúdo em magnetita $(0,75 \%$ em pêso); 32) a martita apresenta un valor de susceptibilidade magnética mil vêzes menor do que o da magnetita, que é da or dem de $300.000 \times 10^{-6}$ uCGS; 40) não pudemos calcular a preci são dos valores absolutos da susceptibilidade magnética do cada material; os valores relativos, porém, não apresentan êrro maior do que $10 \%$.

\section{$* * * * * * * * *$}

As finalidades principais dos levantamentos mag netonótricos da regiẽo de Ipanema foram:

a) estudar a forma e intensidade da anomalia mag nética causada pelas rochas alcalinas em relação ìs encaixantes;

b) investigar as possibilidedes de novas ocorrâncias de magnetita e de apatita.

Frocedimento de campo

Dentro da área das rochas alcalinas foram le- 
vantados perfis magnéticos isolacios (figuras 25 e 26) com as estações espaçadas de cêrca de 20 metros. Ao redor da área da intrusão, o levantamento magnetonétrico acompanhou, em grande parte, o trabaliho de zrovimetria, sendo as estações lo calizadas irregulariente, de 0,5 a $1 \mathrm{~km}$ umas das outras.

A correção da variacão diurna foi feita sempre que necessária. Na área das rochas alcalinas, onde as anomalias alccnçam valores nuito altos e irregulares, não fizemos tal correção, mas, controlamos sempre o trabalho diário repetindo, a intervalos de algumas horas, a leitura numa mesma estação a fim de evitar de operar em dias com tempestades magnéticas, quando as variações podem alcançar centenas de ganas. A ordem de grandeza da variacão diurna na área de nos sa Investigação é de 30 a 40 gamas. A fig. 27 representa a curva de variação diurna entre $80^{\circ 0}$ e 18.00 horas do dia 16-1-64.

0 instrumento utilizado nos levantamentos foi o magnetômetro ABEM, modêlo 3, cujo corte esquemático pode ser visto na fig. 19-B. A parte sensível do instrumento é uma agulha magnética suspensa por meio de um fio metálico horizon tal que passa en seu centro de gravidade. A componente verti cal relativa do campo geomagnético é determinado pela soma das contribuições dos campos magnéticos de dois ímãs compensadores (v. figura). Caracterizam o magnetômetro ABEN o largo alcance da escala de medida, pequena dependência de nivelamento e de orientação azimutal e independência das variações de temperatura; sua precisão é da orden de 3 gamas.

\section{A) Levaritamento magnetométrico regionaI}

Este trabalho, que abrangeu a mesia área do levantanento gravinétrico, teve por escopo obter o mapa regional das linhas de igual componente vertical (fig. 28). Os va Jores que constam dốsse mapa são relativos, tendo sido atrí buído zero à linha isodincínica mais próxima do contato em basamento cristalino - rochas sedimentares. A ordeñ de gran- 


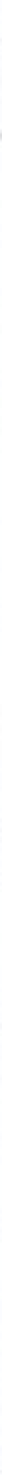

Fig. 25- Perfil magnético E-W. As anomalias correspondem a jazidas (eluviais e in situ) de magnetita. Observar os valores das anomalias na reglão da mina Rica. 


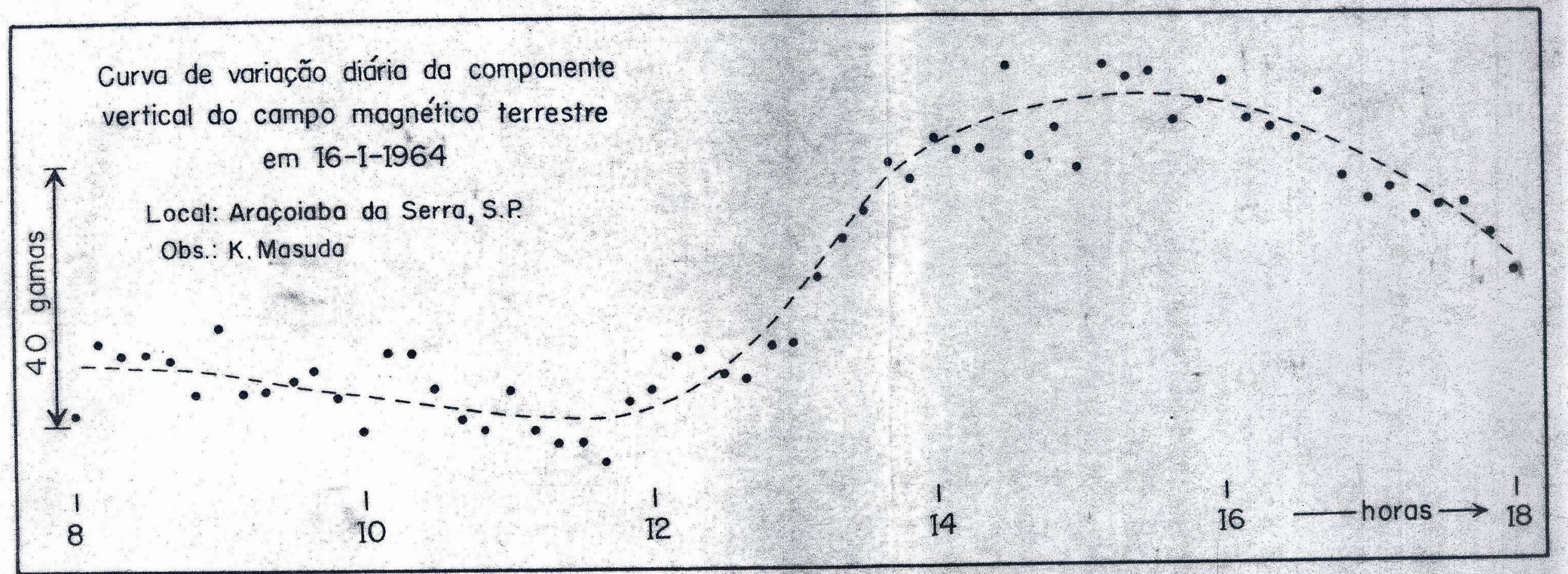

1̇. 27- Curva de variação diária de $\Delta Z$. As leituras foram feitas com o magnetômetro ABEM, de $10 \mathrm{em} 10$ minutos, em uma estação fixa. 


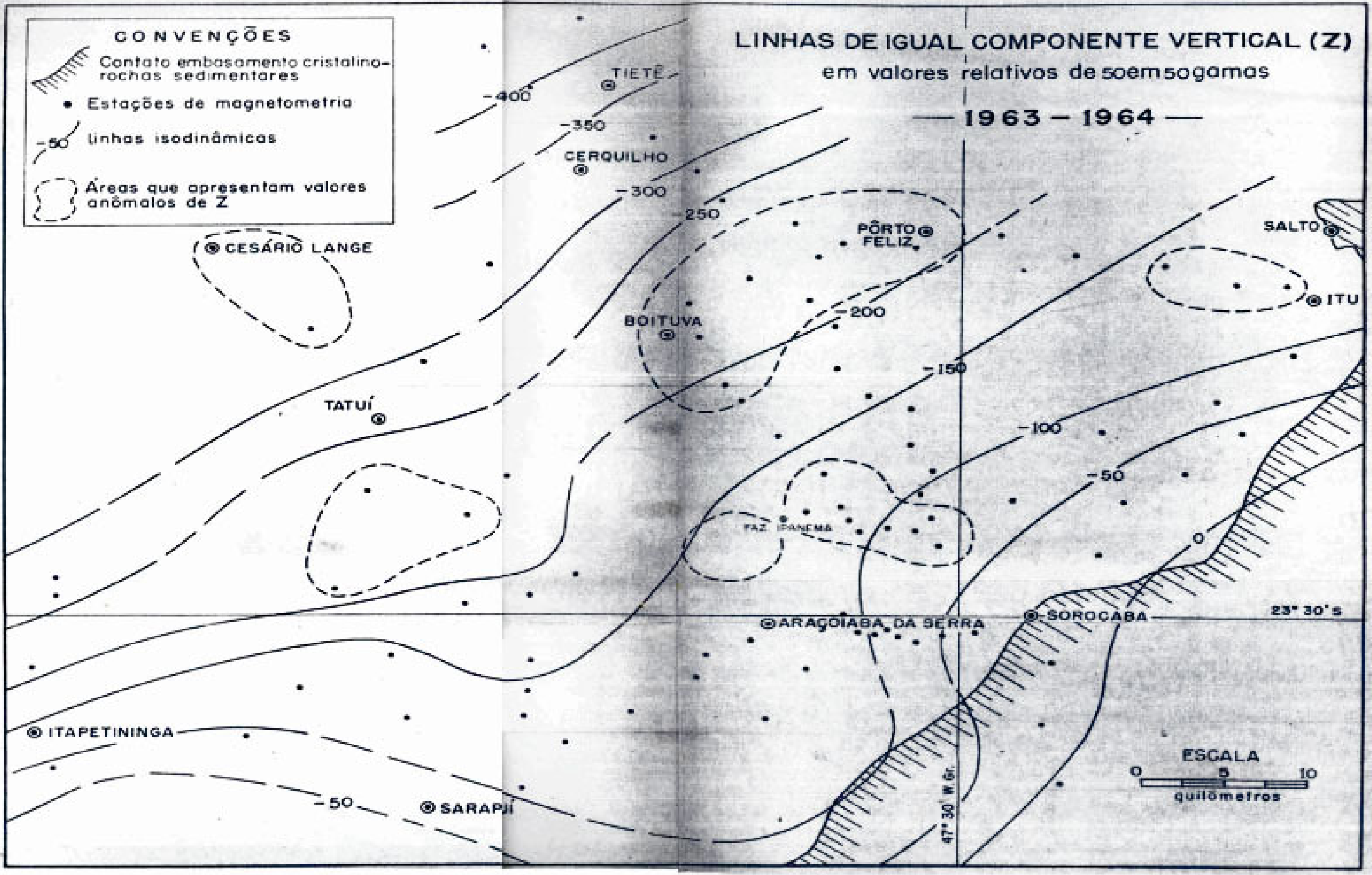

F1E. 2B- Nape dos valores rolntivos da eomponente vertieal do campo gecmnenótice. De soroenba a Iletê, há um decróadmo de 400 gumas no valor remlonal de $\mathrm{z}$. 
deza dos valores absolutos dos elementos do campo geomagnético pode ser obtida das cartas manéticas do Brasil (Gama, 1960). Para a regiâo de Ipanema, a componente vertical (Z) é da ordem de 8000 gamas, a inclinação magnética (I) é de cêrca de -202 e a declinação magnética, de aproximada mente $12 \mathrm{gW}$.

Observa-se no mapa magnćtico que os valores da intensidade vertical ( $Z$ ) decrescem para noroeste de aproxima damente 5 gamas $/ \mathrm{km}$. Esse gradiente, na componente vertical, pode ser explicado como reflexo do mergulho reglonal da topografia do embasamento cristalino para oeste.

O mapa assinala também algumas áreas com valores anômalos de $Z$. Essas anomalias, locais, podem ser atribuidas ذ̀ presença de sills e diques de diabásio próximos à superffcie. No caso da área de Ipanema, a anomalia local é causada pela intrusão alcalina. Trataremos mais pormenorizadamente dessa última no Item seguinte.

\section{B) Levantamento magnetométrico da rogiño de Ipanema}

Os resultados dêste levantanento estão representados na fig. 29. Trata-se do mapa de Iinhas de isoanomalias da componente vertical da região de Ipanema.Devemos res saltar que as linhas tracejadas, que atravessam a área das rochas alcalinas, são apenas fictícias e foram traçadas em continuação às linhas de isoanomalias, que circundam aquela área. o campo magnético na região da intrusão alcalina é muf to irregular e resulta da superposição de anomalias causadas tanto pelo corpo alcalino em si, como pelas concentrações le cais de magnotita.

Observa-se, no mapa, un máximo e um mínimo magnéticos, da orden de 500 gamas, respectivamente a norte e a sul da intrusão alcalina. Interpretanos como o efeito da polarização inclinada apresentadr pelo corpo alcalino. Sendo a inclinação magnética, na área, de aproxinadamente 20\%, aparê 
Fig. 29- Mapa magnético (componente vertical) da região de Ipanema. Notar o efeito de polarização causado pela intrusão alcalina. 
MAPA MAGNETICO

- COMPONENTE VERTICAL-

\section{CONVENCÕES}

$$
-1964-
$$

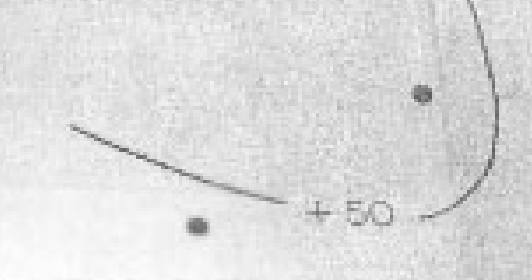

VV CONTÔANO DAS ROCHAS ALCALINAS

$v v_{i}$ CONTÔANO DAS ROCHAS ALCALTMA
$v$ ESTAGÓES MAGNETOMÉTRICAS

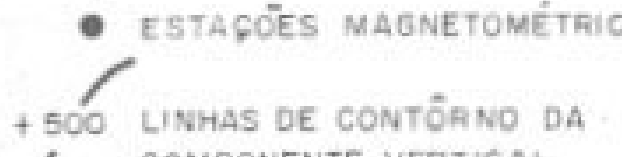

COMPONENTE VERTICAL
MAGNÉTICA EN GAMAS
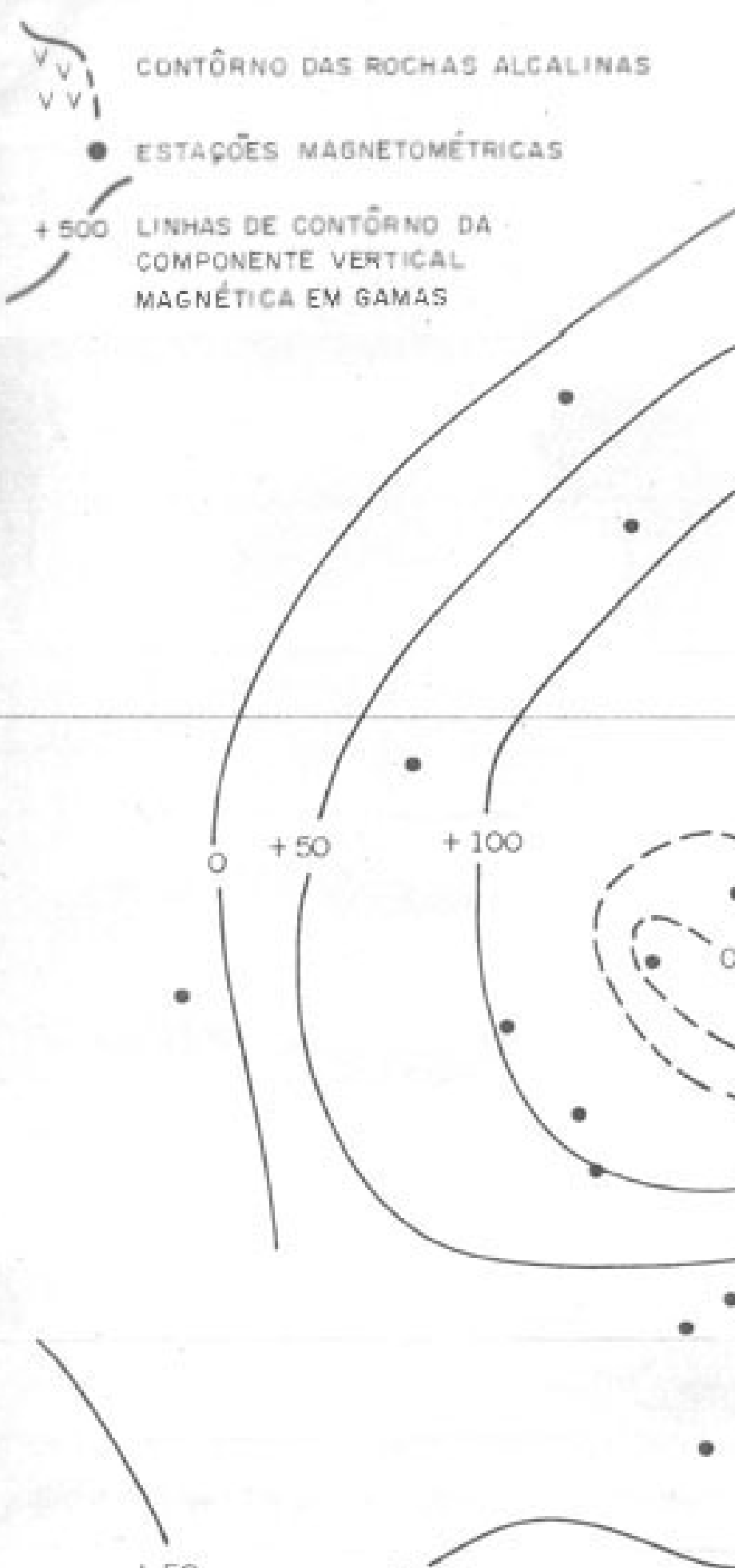

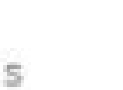

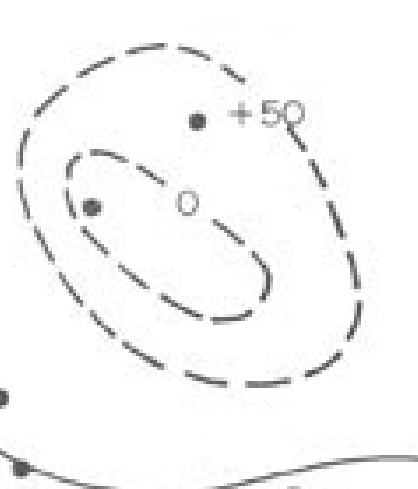


ce, por indução magnética, uma região com polaridade negativa na parte sul do corpo alcalino e outra, com polaridade po sitiva, no exuremo oposto: A direção de polarização coincide pràticamente com a direção do atual campo geomagnético (a de clinação magnética no. região de Ipanena é de aproximadanente 12 W). Deve-se notar que as Iinhas de isoanomalias são alongadas para oeste, cobrinco justamente a área das rochas do embasamento cristalino ( $V$. mapa geológico). Por outro lado, verifica-se que há anomalias locais (linhas fechadas tracejadas) distribuídas por quase tôda a área.

$* * * * * * * * *$

Uma análise qualitativa do mapa demonstra inediatamente tratarmse de área geològicamente complexa. Fica, porém, perfeitamente individualizada a intrusão alcalina de Ipanema. Calculadas de acôrdo com a teoria do potencial, as profundidades dos pólos magnéticos causadores do máximo en nimo magnéticos é da ordem de 300-500 metros.

As linhas de igual-anomalia que se estendem para oeste parecem o efeito de um prolongamento, en nível inferior, da intrusão alcalina.

Nos setores leste e nordeste do mapa, não há anomalias regulares tais que possan indicar a existência de un corpo grande em profundidade, como ficou indicado nos resultados do levantanento gravimétrico (v. fig. 22). Acredita mos, no entanto, que a profundidade dêsse possível corpo seja tal que seu efeito magnético não pode ser fàcilmente detectado e, ainda, que outros efeitos magnéticos mais superfi ciais terian mascarado a possível anomalia, proveniente do corpo indicado pela gravimetria.

\section{()) Levantamento magnético na área da intrusão alcalina}

Dentro do contôrno da intrusño alcalina, as ano malias são muito irregulares e o componente vertical atinge 
valores da ordem de 2000 gamas. 0 trabalho se restringiu ao estudo de perfis magnéticos, levantados em direções conveni entemente escolnidas. Primeiramente, foram executados dois perfis, um, de direção $\mathrm{N}-\mathrm{S}$, outro, E-W, passando aproximadamente pelo centro da área das rochas intrusivas. Posteriormente, foram realizados perfis paralelos ao de direção $\mathbb{N}-\mathbf{S}$, distanclados de cêrca de 600 metros. A localização das direçōes dos perfis, que serão menctonados nas páginas seguintes, é mostrada na fig. 30 .

De acôrdo com os conhecimentos geológicos que se tem da região de Ipanema, podemos atribuir a duas fontes princlpais as causas das anomalias magnéticas na área das"re chas alcalinas:

a) O efeito da polarização do corpo intry sivo;

b) concentrações locals de magnetita.

O Item (a) fol descrito e discutido anteriormen te. 0 efelto de polarização provoca o aparecimento de um mínine magnético a sul da intrusão (de cêrca de -500 gamas) e um máximo, a norte (de aproximadamente +600 gamas). Os valo-

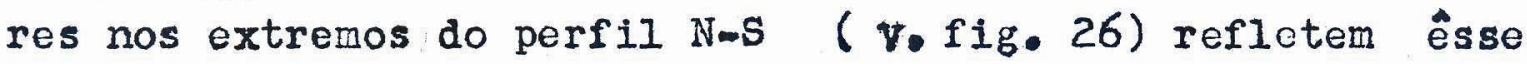
efeito de polarização. Observa-se que, do extremo $\mathbb{N}$ dêsse perfil, em direção ao corpo alcalino, os valores da anodaIla crescem positiva e uniformemente até serem mascarados por outros efeitos magnéticos ̨ no outro extremo, dá-se o oposto: os valores da anomalia decrescem até aproximadamente -500 gamas para, então, serem afetados por distorções provocadas por outras fontes. Estas outras fontes são principal mente as concentrações de magnetita.

Segundo Knecht (1930, pp, 11 a 13), as jazidas de magnetita de Ipanema não somente se encontram in situ, na forma de corpos lenticulares, como também, constituindo eluviơos. Astes passam, às vêzes gradualmente, para a jazida insiitu.

Do ponto de vista da interpretação dos dados 


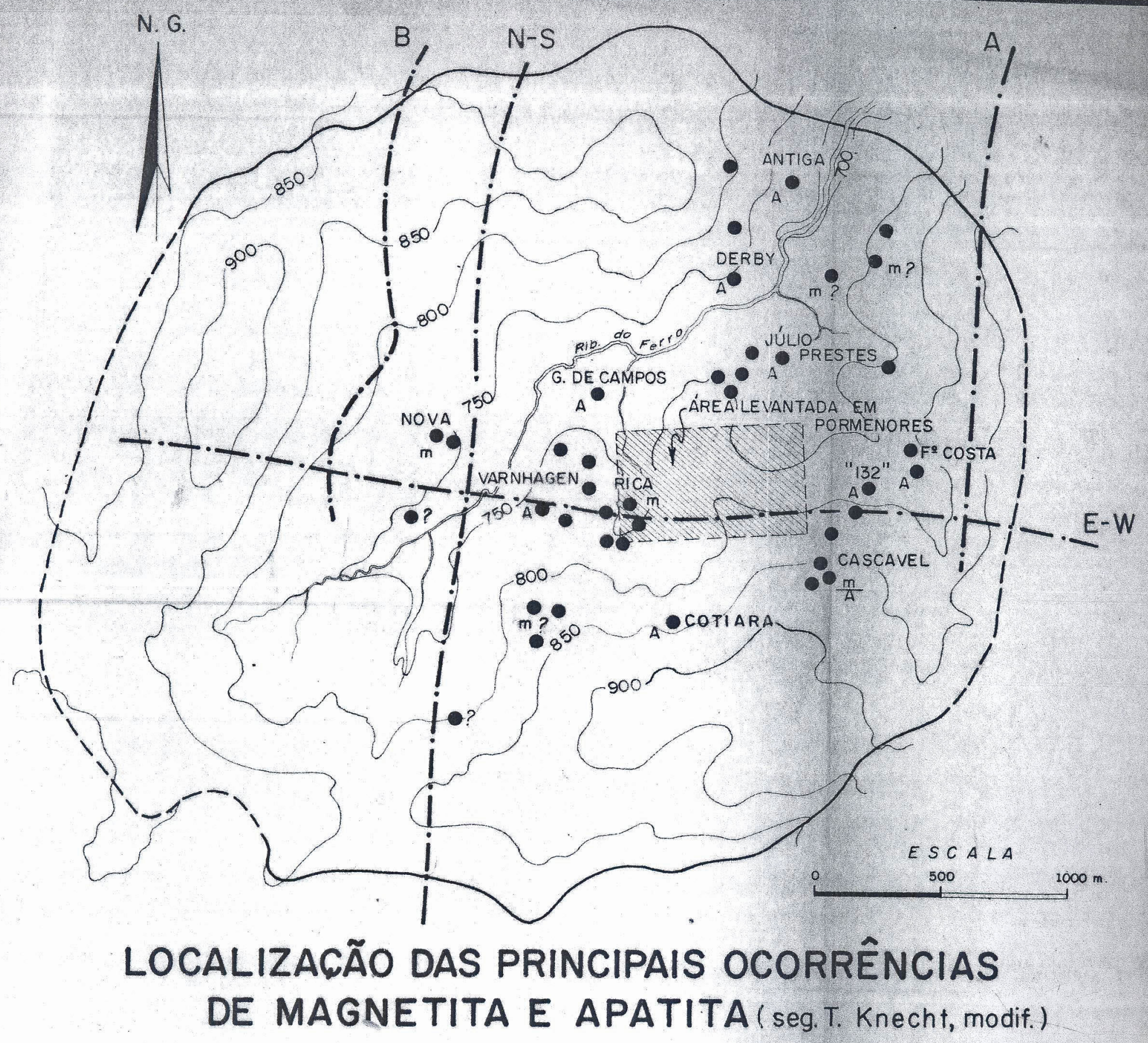

CONVENCOEES: - Localiząão do minério (A-"mina" de apatito $m$-"mina"de magnetita)

- Direcão dos perfis magnéticos

850 - Curvas de nivel de 50 em 50 metros

Fig. 30- Area da intrusão alcalina com as principais

ocorrências de magnetita e apatita. 
magnetométricos, devemos distinguir os três nodos de ocorrêncla das jazidas de magnetita:
1) in situ,
2) eluvial,
3) in situ, passando a eluvial.

Pode-se reconhecer fìcilnente nos resultados de um levantamento magnético quando se trata do caso (1) ou (2). O depósito de nagnetita eluvial produz anomalias muito irregulares, por causa da distribuição caótica dos blocos de rag netita junto à superfície. Contràriamente, depósitos de nag netita in situ produzen anomalias que se destacam freqlentemente por suas formas suaves e regulares. No caso (3), a interpretação se torna mais difícil.

Nos perfis "N-S" e "E-W" estão possiveluente to dos os três tipos de anomalias acima descritos. A comprovação da natureza de cada tipo exige, porém, verificação das condições geológicas, no locali e extensão do levantamento mag nético a outros pontos próximos. Vanos analisar alguns dos resultados mais ilustrativos da investigação magnetométrica.

\section{Perfil nagnético "B"}

O perfil magnético "B" (fig. 31) pode ser mencionado cono exemplo de anonalia causada pela presença de magnetita in situ. Está locrlizado no flanco sul do norro do Paletó e nenhuma jazida é conhecida ao longo de sua dire ção (v. fig. 30). Estudo pormenorizado da anomalia será rea lizado en trabalho à parte, nas, pode-se adiantar, desde já, que a profundidade da fonte crusadora dessa anomalia é da ordem de 100 a 200 metros.

0 perfil "B" indicou a possibilidade de se encontrar jazidas de nagnetita em profundidade, com as mesmas dinensões ou até maiores do que as encontradas na superff- 


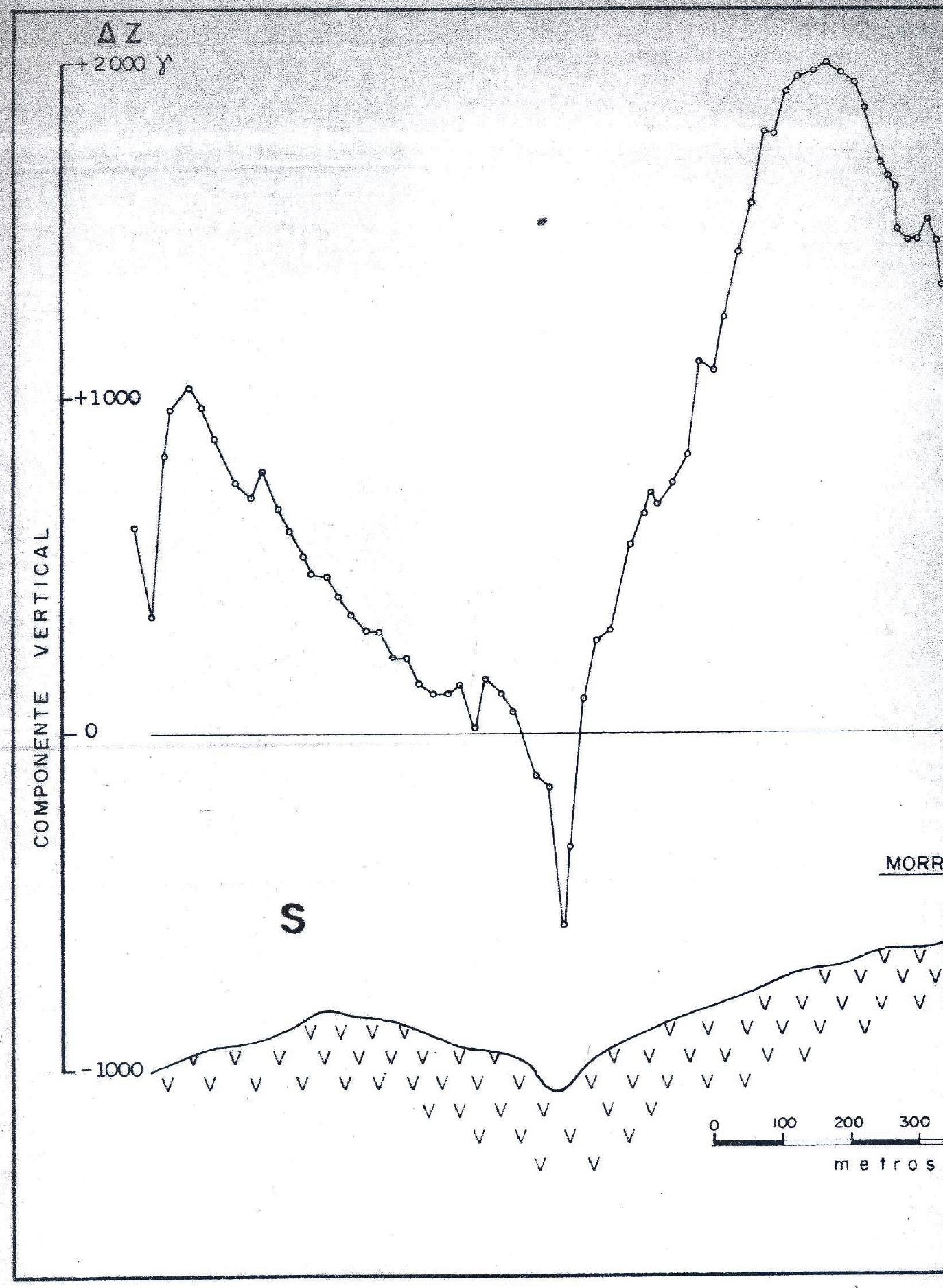

Fig. 31- Perfil magnético "B". A forma e a intensidade dessa anomalia indicam a presença de um cor po altamente magnético em profundidade. 


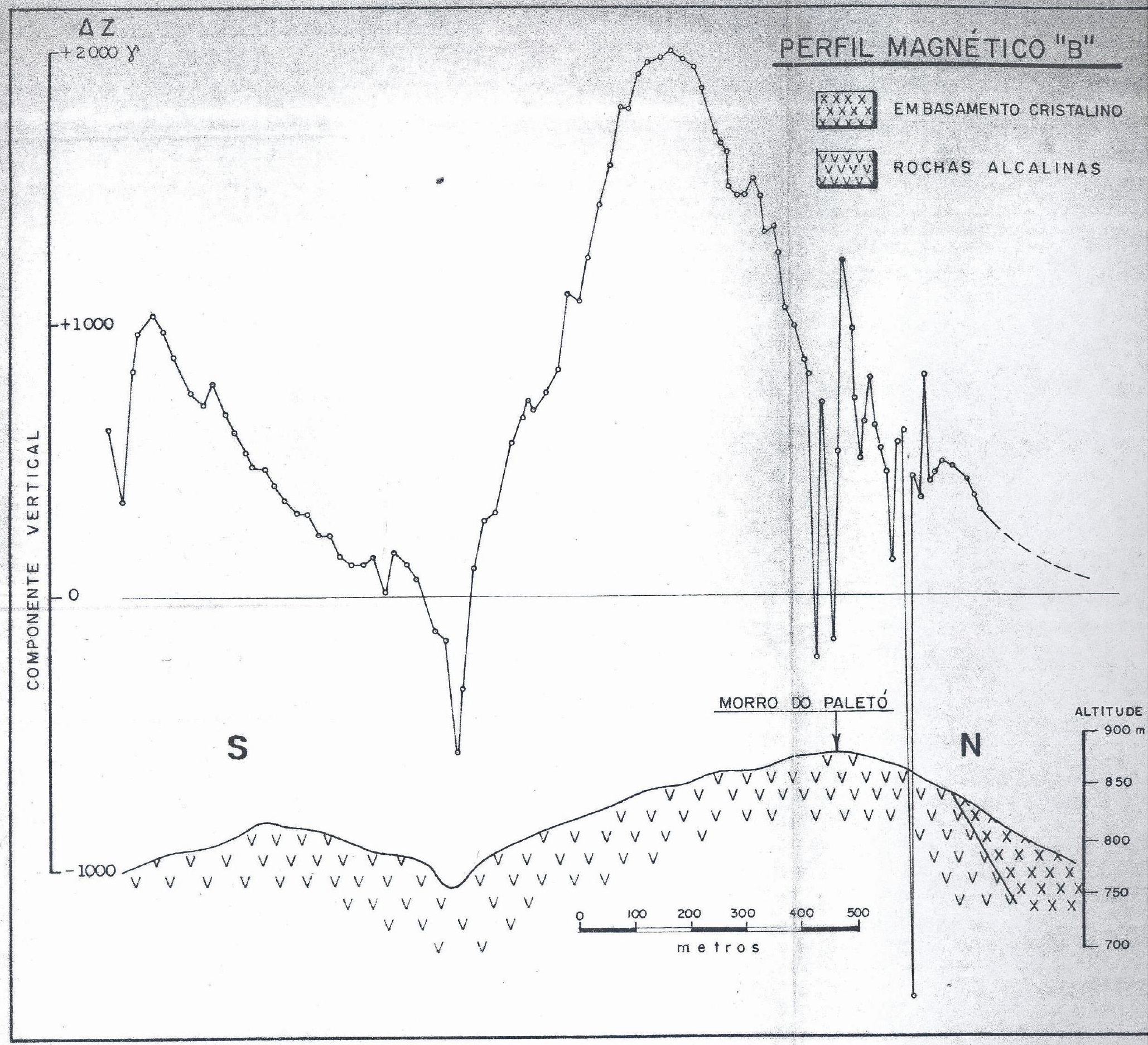

Fig. 31- Perfil magnético "B". A forma e a intensidade dessa anomalia indicam a presença de um cor po altamente magnético em profundidade. 
cie. As jazidas conhecidas são lenticulares e raramente apre sentar mais de 100 in de comprimento, senao suas outras dimen sões de poucas dezenas de metros.

\section{"Mina" Rica}

Citaremos a "mina" Rica (v. localização na fig. 30) como exemplo de jazida de magnetita eluvial que passa a jazida in situ, em profundidade.

o que chamou atenção sôbre esta região fol a Lorma e a intensidadé da anomalia magnética correspondente, registrada no perfil "E-W" (v. fig. 25). Foi feito un levantamento pormenorizado cobrindo área de aproximadamente 400 por 800 metros. A rêde de estações e os resultados do levantanento poden ser vistos na fig. 32.

Estes resultados, colocados como mapa de linhas de isoanomalias da componente vertical, deve ser encarado a-

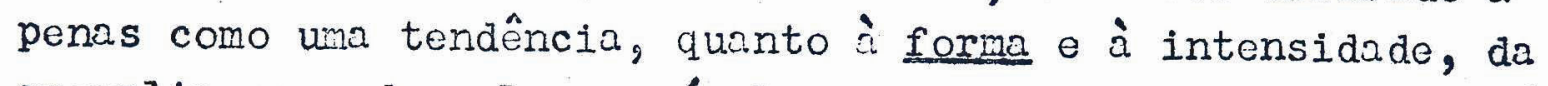
anomalia causada pelo provável corpo de ragnetita in situ. E un mapa muito simplificado e foi obtido por una tentativa en pírica de isolar as contribuições dadas pelo naterial eluvial, daquelas causadas pela jazida in situ. Para isso, examinamos cada perfil magnético, obtido no longo das linhas de observação, e traçanos a curva que melhor representava a con tribuiçăo do provável corpo magnético en profundidade. 0 per fil magnético da fig. 33 ilustra o procedimento. 0s: picos mis abruptos, ao longo do perfil, são encarados como provenientes da contribuiç̃o do naterial eluvial. E un processo artificinl, poróm, a única maneira prótica que encontramos de obten a provivel forre da anomalia magnética.

Devemos obsertar no mapa magnético da região da "minn" Filca: Io) que as anomalias elcançam valores da orden de +4000 gamas; 20) a forua alongaka da anomalia na direção wroximadanente $N 70$; 30) colicando-se a regra da meia-largure los resultados apresentados no mapa de linhas de isoanoma 


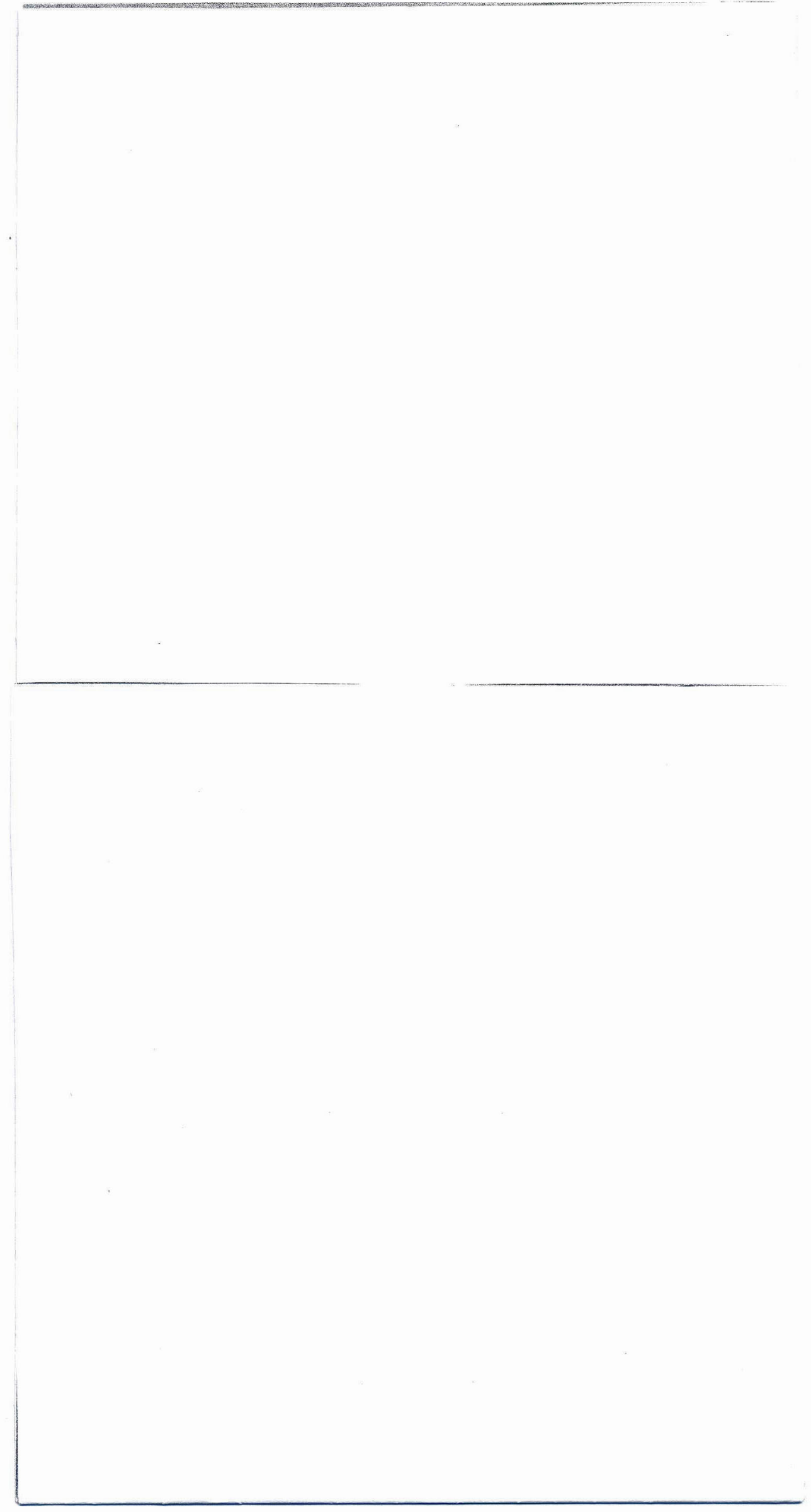

Fig. 32- Mapa magnético (componente vertical) da região da "mina" Rica. As linhas isodinâmicas são alongadas na direçẽo NE-SW. 


\section{REGIÃO DA "MINA RICA"}

- Resultados da

Interpretacão dos dados de Magnetometria

(linhas de isanomalias com valores em gamas)

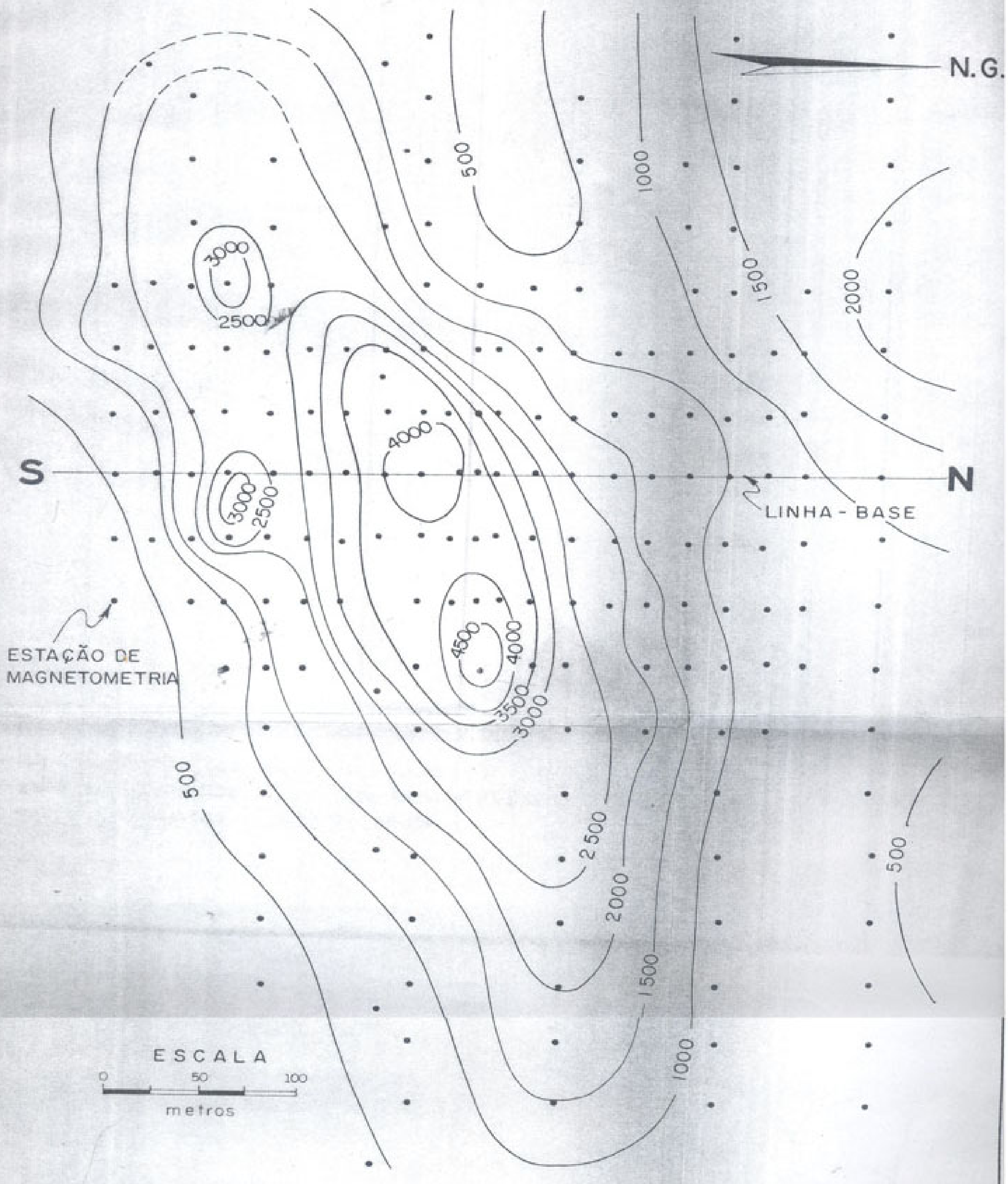


lias, pode-se avaliar que a profundidade do corpo de minério é da ordem de 70 metros.

D) O método masnetonétrico como auxiliar no levantamento geológico de Ipanema

o nétodo magnetométrico auxiliou grandemente no levantamento geológico da região de Ipanema, principalmente na demarcação dos contatos ocultos entre as rochas.

As três unidades estratigráficas mapeadas ( $v \cdot$ ma pa geológ1co) apresentam intensidade e forma de magnetização bem distintas. Vejamos, por exemplo, o perfil magnético "Ä" (fig. 34). Esse perfil tem direção norte-sul e atravessa, a partir do norte, rochas sedimentares, filito e rochas alcalinas (r. localização do perfil "A" na fig. 30). Sôbre os sedimentos, os valores do campo magnético são pràticamente constantes; aurentam gradualmente para un nível com una a duas centenas de unidades (gamas) mais alto, na presença de rochas do embasamento cristalino e, finalmente, sôbre as rochas alcalinas, tornam-se muito irregulares, atingindo va lores excepcionalmente altos, dada a presença das concentra ções de magnetita. Tal seqlência foi observada, quase sempre, facilitando sobremaneira o levantamento geológico.

\section{E) Resumo das conclusões principais}

1) O levantamento magnetométrico individualizoi a intrusî́o alcalina, indicando possível prolongamento, om subsuperfície, para W-SW (v. fig. 29). Esse prolonganento da intrusão localizarmse-ia a algumas centenas de metros de pro fundidade e seria responsávej. pelo soerguimento do embasamen tu cristalino naquele setor. No setor oposto, isto é, E-NE da sntrusão alcalina, $\dot{a}$ despoito do alto gravinétrico veri- 


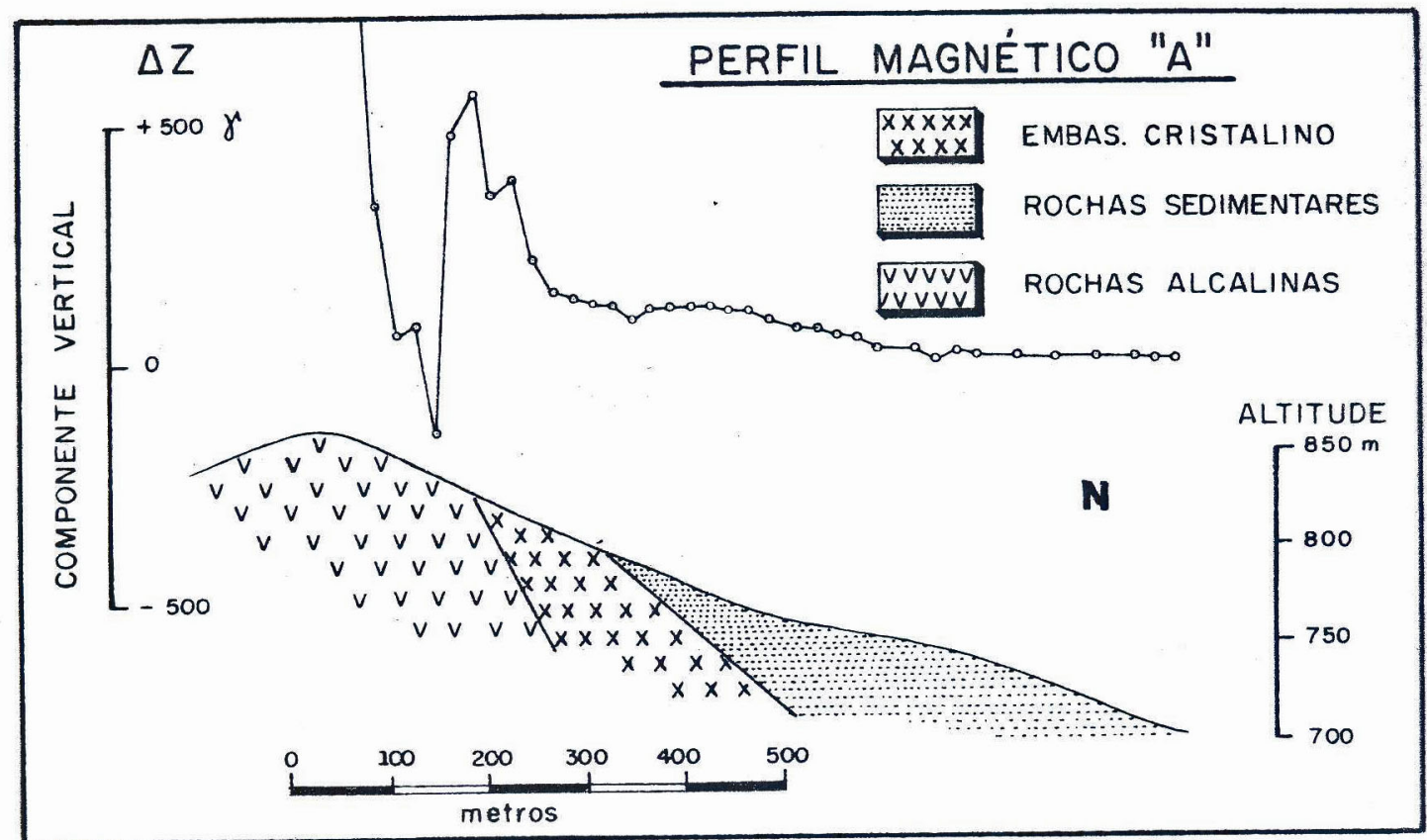

Fig. 34- Perfil magnético "A". Os valores de $\Delta Z$ mantêm-se no nível zero sôbre os sedimentos, crescem nas proximidades e sôbre o embasamento e são muito irregulares sôbre as rochas alcalinas. 
ficado (v. fig. 22): não há evidência magnética de um corpo Igneo, pelo menos, a pequena profundidade. Como o embasamento cristaiiro, neste setor, não sofreu o mesmo deslocamento vertical que no quadrante W-SE, acreditamos que o cor po indicado pela gravimetria deva encontrar-se a mais de $I$ km de profundidade.

2) Alguns perfis magnéticos demonstram a eficlência do método como auxiliar na prospecção de jazldas de magnetita. Há Indicações da existência de jazidas desse mineral em profundidade (perfil magnético "B", fig. 3I).

\section{$* * * * * * * * *$}

Quanto às ocorrências de apat1ta de Ipanema, não vemos, no momento, possibilidade de um dos métodos geofísicos auxiliar diretanente na prospecção, a não ser que, havendo relações bem definidas entre essas concentrações e as de magnetita, possam os dados magnetométricos ser usados indiretamente. Por exemplo, poder-se-ia excluir algumas áreas, onde possivelmente predomine a magnetita, e Iniciar a pesquisa, por meio de sondagens, nas demais áreas. 


\section{$V$ - COYCLUSOHE TIISAS}

a) Lecanis sno da intrusão alcalina

1. A intrusão alcalina de Ipanema fol, essencialmente, do tipo injecão forcada. is rochas encaixantes fo ram deslocadas verticalnente até centenas de metros de sua posiçăo inic1al, iormanco ume estrutura dômica. is superfície do embasamento cristalino, bein cono as camadas do Grupo Tubarăo, apresentam mergulhos dc ordem de $15^{\circ}$ para fora da in. trusăo.

As diécloses de tensão e as falhas escalonadas, observadas na região da serra de siraçoiaba, eonstituem outras evidências do processo ativo de colocacão do megrina. is diáclases desenvolvidas no Grupo Tubarăo distribuiran - se radlal e concêntricanente ao redor de área das rochas alcali nas. Is falhas apresentar rejeito de ordem de alguns metros ou poucas dezenas de netros e parecen formar dois . slstcmas um, paralelo ¿̀ direção da xistosidade das rochas do embasamen to cristalino e outro, perpendicular a essa direção.

2. Dados geológicos e geofísicos demonstram o contrôle exercido jelas estruturas regionais do complexo eris talino sôbre o rodo de colocacão do magma.

is rochas alcalines de Ipanema são encontradas princivalmente no longo dos planos da xistosidade das rochas cncaixantes, cs qucis foram on parte "fenitizadas" pelo magma. Alinham-so na direção da xistosidade quase tôdas as jazidas conhecidas de nagnetita e apatita e o traçado do ribcirão do Terro, no árca das intrusivas alcalinas, obcdoco à direção imposta por essc estrutura dos metassedimentos. 
Os resujtados do leventcuento grevinétrico indicam que, on profundiace, o megne alcelino colocou-se também co Iongo dè direção des estrutures regionais do embasamento cristalino, nume reixa de algures dezenas de quilôrom tros, cujo centro compos onde hojo co olto de serra de irrçoicba.

Adnitinos que o meone tenhe penetrado por : fraturas, deseivolvides ne crosta terresire, perelelemento is estruturas regionais do comploxo cristajino. Constituiu, dês se modo, diversos cornos tabulares anoxinedanonte verticals (v. fig. 35). Un dêstes corpos serice o dique de shoninitopórfiro, situado no beirro de Congonhol (Tatuí), aparentenen te isolado de qualquer meni ostação negrática.

Epeciso adnitir tanbém que grande parte do megne cristalizou-se no interior do ombasanento cristalino, sein alcençr o Grupo Tuberc̃o, pois, os estudos gravinétricos indican que a fonte das chonalias se situa c. alguns quilônetros de profundidede. Sómente na regico da scrra de iraçoiaba, o magne teric consoguicio, por un processo ativo (injecsio Eorcada), soerguer as pochas enccixcntes, alccnȩando níveis mais elcvados.

b) Depósitos de megnetite a epatita

1. Os perfis magnéticos lovantcoos permitiram diforoncior as jnaidos do negnetita in situ das oluviais. is invostigacoos rovelan quo a quantidade dôsso minoral, na for me do concentragño rosidual, é muito grende. ilá, no entanto, indícios do existência do jazides de mesnetita, can profundidace de orden de uma a duss centones de notros, de dinensões irzuais ou naioros do que aqueles encontrades en superfícic (porfil magnético "B", fig. 31). Ls maioros jazidas de magne tita conhecidas são lonticulares o possuem cêrca de $100 \mathrm{me}$ - 


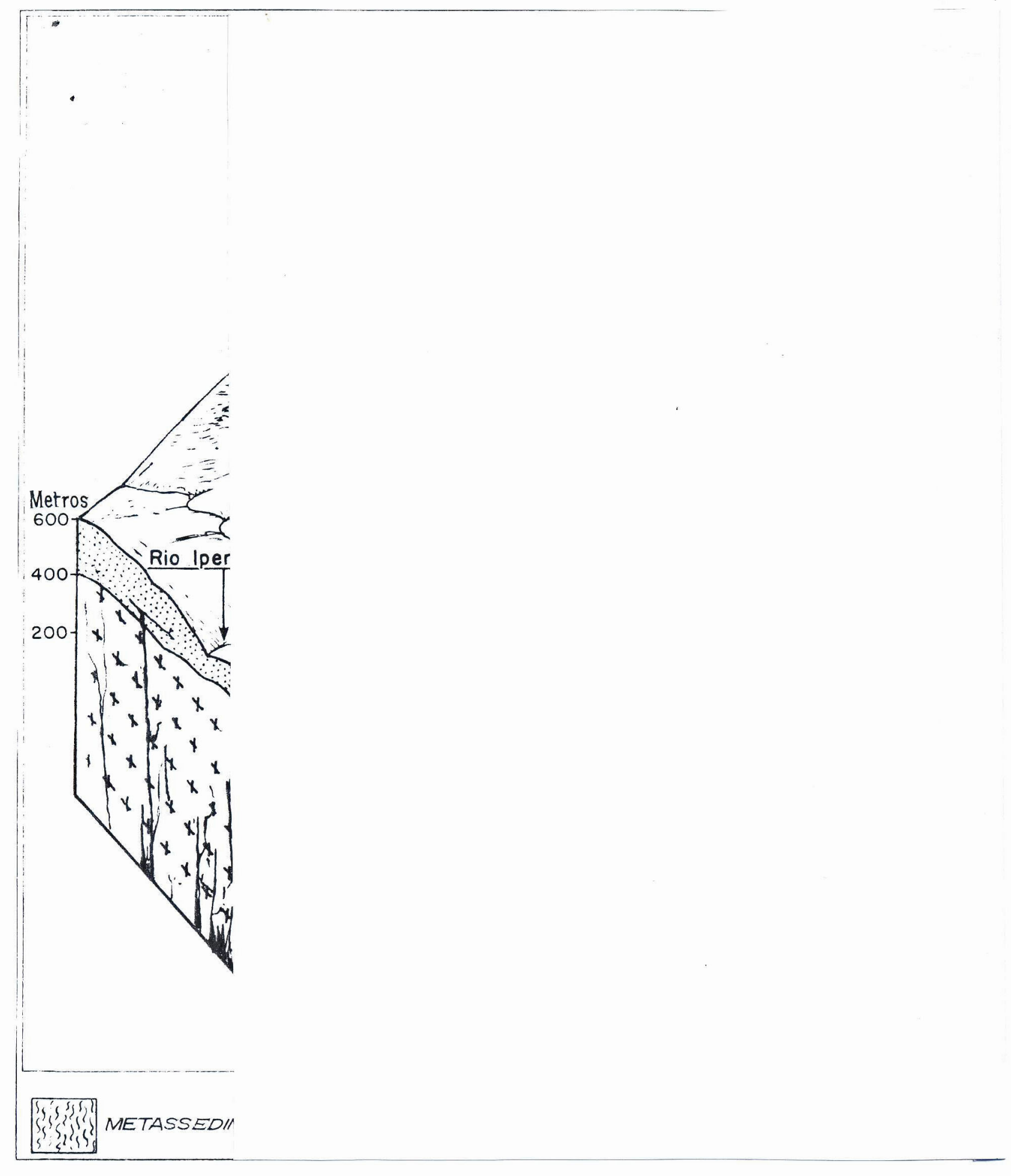

Fig. 35- Bloco-diagrama da região da serra de Araçolaba, de acôrdo com as interpretações dos dados geológicos geofísicos. 0 magma injetou-se ao lon go das estruturas regionals do embasamento cris talino. 
tros de compimonto por 10 motros de largura.

2. Invastifacõos meßnetométricos poderão tembóm euxiliar, indirctencnte, ne prospecção dos depósitos de apatita, desde que sojan foitos estudos pormenorizados das releçõos existontos entio cissos de ósitos e os de nagnctita. 


\section{VI - BIBLIOGRAFIA}

AMARAL, I. C. do, ODDONE, D. S. e OLIVEIRA, G. M. A.-(1936) Levantanento magnético de írea de São Podro=: Xarqueada, Dep. INac. Prod. Min., Serv. Fom. Prod. Min., Bol. 10, pp. 3-22. Rio de Janeiro.

AMARAL, S. E. - (1961) - Silicificacão intersticial de arenitos de Sersipe (Série Barreiras) e de Varnhagem, São Paulo (Série Itararé), Bol. Soc. Bras. Geol. vol. 10 n. 1, 79-99. São Paulo.

ARAUJJO, J. B. de - (1939) - Beneficiamento de apatita en Ipanema, Est. de São Paulo, Min. Metal. vol. III, n. 17, pp. 299-305. Rio de Joneiro.

BACKLUND, H. G. - (1933) - On the mode of intrusion of deep seated alkaline bodies, Bull. Geol. Inst. Upsa 1a, vol. 24, pp. 1-24.

BIRCH, F., SCHAIRER, J. F., CECIL SPICER, H. - (1942) Handbook of physical constants, Geol. Soc. Am. Special Papers n. 36, p. 296.

BARBOSA, O. e ALMEIDA, F. F. M. - (1949) - Nota sôbre a estratigrafia da Sćrie Tubarão em São Paulo, Ac. Bras. Ciên., Anais t. XXI n. 1, pp. 65-68. Rio de Janeiro.

- (1949) - A Série Tubarão no bacia do rio Tietê, Est. de São Paulo, Div. Geol. Min., Notas Prel. e Estudos n. 48, 16 pp. Rio de Janei ro. 
DERBY, 0. H. - (1891) - On the mognotite ore districts of Jacupiranga and Ipaneria, S̃̃o Paulo, Brazil, hin. J. Sci, vol, XII $\mathrm{n}, 141, \mathrm{pp}$. 311-321. New Haven.

DOBRIN, M. B. - (1952) - Introduction to geophysical prospecting, MaGraw-Hill Book Co. Inc. Nova York.

DUPRE, L. - (1884) - Memória sôbre a fábrica de ferro de S̃̃o Jo ̃o de Ipaneria, Anais da Escola de Minas, n. 6. Ouro Preto.

FREITAS, R. O. de - (195I) - Insaio sôbre a tectônica moderna do Brasil, Fac. Fil., Ciên. Lêtras da Univ. S̃̃o Paulo, Bol. 130 (Geologia n. 6), $120 \mathrm{pp}$. S̃̃o Paulo

GhMA, L. I. - (1960) - Distribuiç̃o geográfica do canpo nag nético e sui variacão secular no Brasil, Min. Educ. Cultura, Publ, do Serv. Magn. n, 9, 16 pp. Rio de Janeiro.

GRIFFIN, L. W. - (1949) - Residual gravity in the theory and practice, Geophysics, vol. XIV, n. I, pp. 39-56. Tulsa.

JAKOSKI, I. I. - (1950) - Exploration geophysics, Trija Publishing Co., pp. 1-579. Los Angeles.

KiNG, Y. - (1961) - on the anowalies of the geomagnetic field due to Nt. Kabuto, Hyogo Prefecture, Japan, Nemoires of the college of Science, Univ. Kyoto, Series B, vol. XXVIII, n. 2 .

KNECHT, T, - (1930) - Notas geológicas sôbre as jazidas de maneitita e apatite de Ipanema, Secretaria igr. Ind. Con. do Est. de S̃̃o Paulo, 29 pp. S. Paulo. 
- (1960) - Notas preliminares sôbre novas ocorrências de rochas alcalinas no Estado de são Paulo, Bol. Soc. Bras, Geol., vol. 9 n. I, pp. 71-76. Sะ̃o Paulo.

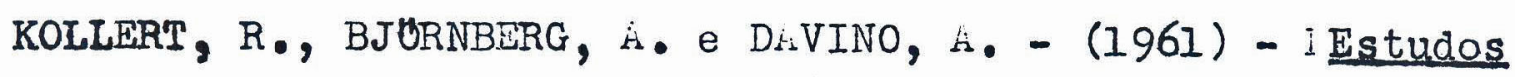
prelininares de una depressĩo circular na regiño de Colônia: Sto, Amare, S̃̃o Paulo, Bol. Soc. Bras. Geol., vol. 10, n. 1. pp. 57-77 - . São Paulo.

\section{LEINZ, V. - (1937) - Estudos sôbre a glac1acão perno-car- bonffera do sul do Bras1l, Dep. Nac. Prod. Min., Ser. Fom. Prod. Min. Bol. 21,52 pp. Rio de Janeiro.}

(1940) - Petrologia das jazidas de apatita de Ipanera (Estrdo de São Paulo).Dep. Nac. Prod. Nin., Div. Fon. Min., Bol. 40, 52 pp. Rio de Janeiro.

(1949) - Contribuicão à geologia dos derrames basálticos do sul do Brasil, Fac. Fil., Ciên. Lêtras da Univ. de Sc̃o Paulo, Bol. 103 (Grologia n. 5), 72 pp. Sc̃o Paulo.

MiCIEL, P. e GUIMIRTES, J. E. P. - (1955) - A mina de verHiculita de Consonhal, Tatuí, Est. de São Pau1o, Bol. Soc. Bras. Geol., vol. 4 n. I, pp.2741. São Paulo.

MHLAMPHY, C. M. - (1936) - Magnetic prospecting in Santa Catharina, Braxil, Geophysics, vol. I, n. I, pp. 23-47. Tulsa.

MAPTIN, H. MiTHIiS, M. e SIMPSON, I. S. W. - (1960) - The Damar land sub-volcanic ring complexes in South West Arica, International Geol. Congress, Part III, p. 173. Copenhagen. 
MATTOS, $\mathrm{H}_{\text {. }}$ - (1955) - Notas sôbre nivelamentos baroné tricos, Rev, Bras. Geogr. n. 2, ano XVIII, pp. I76́m. Re. Rio de Janeiro.

MENDES, J. C. - (ICSI ) - Langella, nôvo gênero de Lingulídeo da Série Tubarão, Bol. Univ. Paraná, Geologia n. 5, 8 pp. Curitiba.

MEZZHLIRA, S. - (1958) - Dados sôbre água subterrânea na Série Passa-Dois e Tubarão do Est, de São Paulo, Bol. Soc. Bras. Geol. vol. 17 n. I pp. 4973. São Paulo.

MOREES, L. J. de - (1938) - Jazidas de apatita de Ipanema, Est. de São Paulo, Dep. Nac. Prod. Min., Scrv. Fom. Prod. Min., Bol. n. 27, 50 pp. Rio de Janeiro.

NOR:IS RÊGO, L. F. de - (1938) - Recursos brasileiros en natérias primas dos a cubos fosfatados, Min. Me tal., vol. III, n. 12, pp. 377-381; n. 13, pp. 25-29. Rio de Janeiro.

NETTLETON, I. L. - (1942) - Gravity and magnetic calculations, Geophysics, vol. VII, n. 3, pp. 293310. Tulsa.

NEVIN, C. M. - (1949) - Principles of strutural geology, John Wiley \& Sons, Inc., 410 pp. Nova York.

PONELL, H. E. e MILLER, C. K. - (1963) - Magnetic susceptibility of siderite, Bureau of Nines Report of Irvostiati ne, $n, 6224$. Washington.

FUTZFR, HA - (1955) - Geologia da fôlha de Iubarão, Est. de Sta. Catorina, Dep. Nac. Prod. Min., Div. Fom. Prod, Min。, Bol. 96, 94 pp. Rio de Janeiro. 
ROSENBUSCH, C. H. F. - (1870) - Das Eizenerz-Lager von São João d'Ypanema in Brazilien und das Vor Kormen des Martit vineralische und geognost. Freiburg.

SHITH, H. T. U. - (1943) - Acrial photosraphs and their applications, Appleton-Century-Crofts, Inc., 372 pp. Nova York.

TALIBERTI, L. et alt. - (1962) Nivelamento geral do EstadoAltitudes de precisão, Inst. Geogr. c Geol.Bol. 36,101 pp. Sล̃o Prulo.

VOROBIEVA, O. A. - (1960) - AIcali rocks of the U.S.S.R., International Gool. Congress, Part III, pp. 7-17. Copenhagen. 
INSTITUTO DE GEOCIENCIAS - USA
- BIBLIOTEOA-TI139

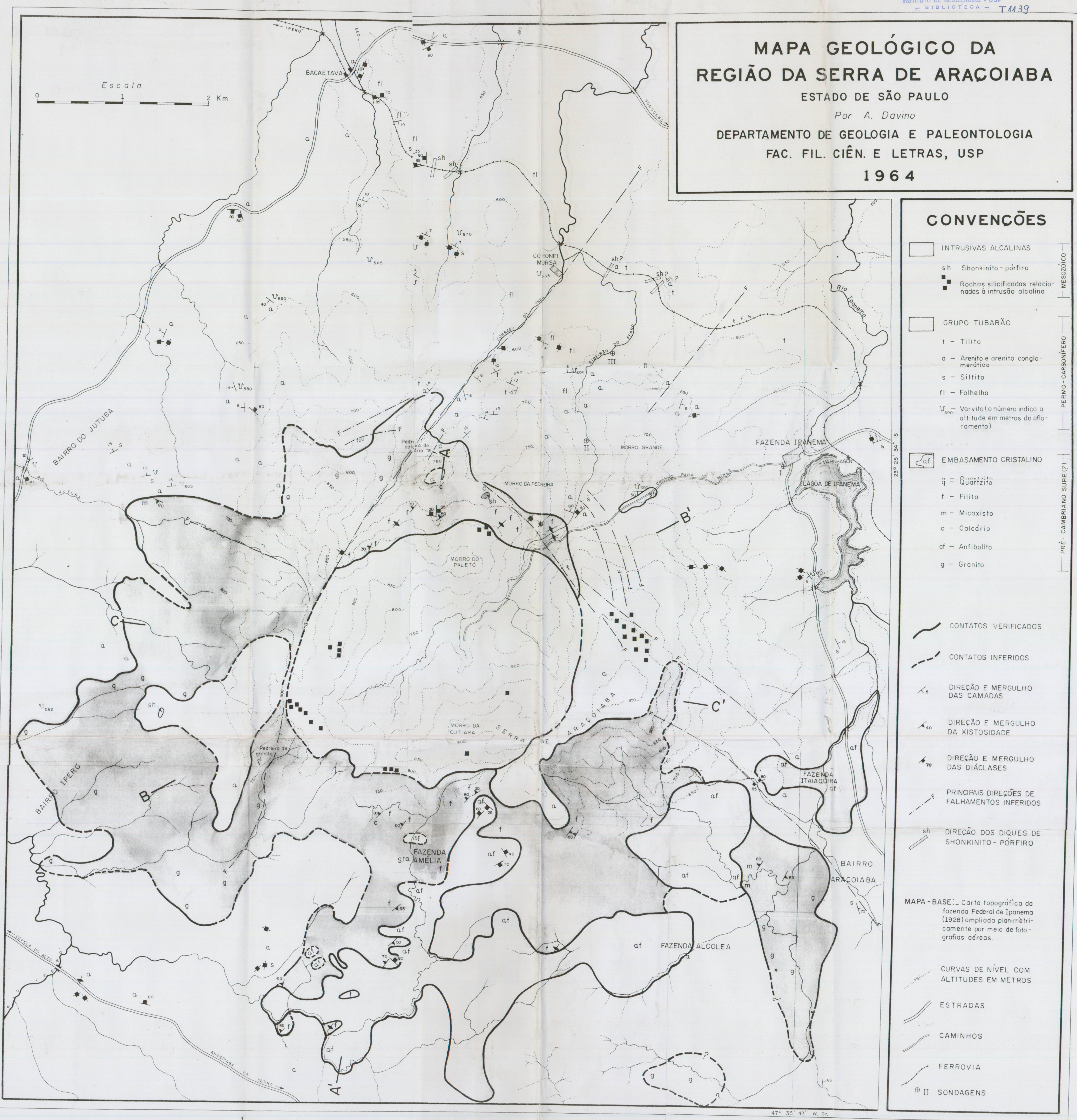

